Portland State University

PDXScholar

Winter 3-22-2018

\title{
"Agglutinating" a Family: Friedrich Max Müller and the Development of the Turanian Language Family Theory in Nineteenth-Century European Linguistics and Other Human Sciences
}

Preetham Sridharan

Portland State University

Follow this and additional works at: https://pdxscholar.library.pdx.edu/open_access_etds

Part of the History Commons

Let us know how access to this document benefits you.

\section{Recommended Citation}

Sridharan, Preetham, "'Agglutinating" a Family: Friedrich Max Müller and the Development of the Turanian Language Family Theory in Nineteenth-Century European Linguistics and Other Human Sciences" (2018). Dissertations and Theses. Paper 4341.

https://doi.org/10.15760/etd.6234

This Thesis is brought to you for free and open access. It has been accepted for inclusion in Dissertations and Theses by an authorized administrator of PDXScholar. Please contact us if we can make this document more accessible: pdxscholar@pdx.edu. 


\title{
“Agglutinating” a Family:
}

Friedrich Max Müller and the Development of the Turanian Language Family Theory in Nineteenth-Century European Linguistics and Other Human Sciences

by

Preetham Sridharan

A thesis submitted in partial fulfillment of the requirements for the degree of

\author{
Master of Arts \\ in \\ History
}

Thesis Committee:

Richard H. Beyler, Chair

Chia Yin Hsu

James Grehan

Portland State University

2018 
(C) 2018 Preetham Sridharan 


\begin{abstract}
Some linguists in the nineteenth century argued for the existence of a "Turanian" family of languages in Eastern Europe and Northern Asia, claiming the common descent of a vast range of languages like Hungarian, Finnish, Turkish, Mongol, Manchu, and their relatives and dialects. Of such linguists, Friedrich Max Müller (1823-1900) was an important developer and popularizer of a version of the Turanian theory across Europe, given his influence as a German-born Oxford professor in Victorian England from the 1850 s onwards. Although this theory lost ground in academic linguistics from the mid twentieth century, a pan-nationalist movement pushing for the political unity of all Turanians emerged in Hungary and the Ottoman Empire from the Fin-de-siècle era. This thesis focuses on the history of this linguistic theory in the nineteenth century, examining Müller's methodology and assumptions behind his Turanian concept. It argues that, in the comparative-historical trend in linguistics in an age of European imperialism, Müller followed evolutionary narratives of languages based on word morphologies in which his contemporaries rationalized the superiority of "inflectional” Indo-European languages over "agglutinating" Turanian languages. Building on the "Altaic" theory of the earlier Finnish linguist and explorer Matthias Castrén, Müller factored in the more primitive nomadic lifestyle of many peoples speaking agglutinating languages to genealogically group them into the Turanian family. Müller's universalist Christian values gave him a touch of sympathy for all human languages and religions, but he reinforced the hierarchical view of cultures in his other comparative sciences of mythology and religion
\end{abstract}


as well. This picture was challenged in the cultural pessimism of the Fin de siècle with the Pan-Turanists turning East to their nomadic heritage for inspiration. 


\section{Acknowledgements}

First and foremost, I would like to thank my main advisers in history Dr. Richard Beyler and Dr. Chia Yin Hsu for their teaching, guidance, encouragement, and support throughout my thesis work. Their close mentorships were valuable in helping me improve my understanding of nineteenth- and twentieth-century European and Russian intellectual and cultural histories. This background shaped the development of my thesis topic on the life of Friedrich Max Müller-about whom I was long curious given my own interests in the Romantic period, the history of linguistics and languages, and folk traditions. It was also through some of my advisers' classes and readings that I first came across the nineteenth-century concept of a Turanian family, which was an obscure name to me at first. From there, it was an intellectually-fulfilling journey to trace the evolution of this idea over time. I am grateful for all the constructive criticisms and help I received, without which it would have been hard to bring my thesis to completion.

I am also thankful to Dr. James Grehan and Dr. Steven Fuller for their comments on this thesis, for the classes I had with them, and for motivating me to continue my studies in history. Their classes helped me become more confident as a history student.

I am also indebted to my family, especially my mother Krishnakumari and my grandparents Ammulu and Doraisamy. Their constant support made my thesis work even more enjoyable and gave me the energy to meet the challenges that came along the way.

The resources at Portland State University's library, its international interlibrary loan system, and the Summit regional borrowing facility were moreover of invaluable assistance in accessing numerous nineteenth-century sources and historiographical texts. 


\section{Table of Contents}

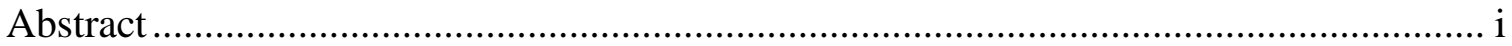

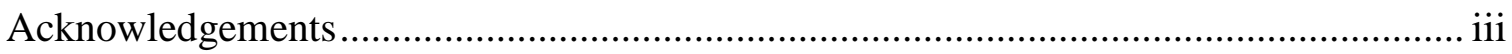

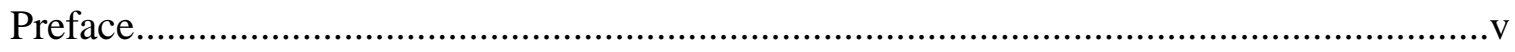

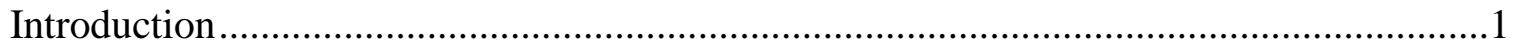

Chapter1

The Idea of a Turanian Language Family in Early-Nineteenth-Century Linguistics ........21

Chapter 2

Family, Nomad, and State Languages: Max Müller and the Turanian Languages

Theory in the $1850 \mathrm{~s}$

Chapter 3

The Geological Stratification of Language: The Turanian Theory in Müller's

Construction of the Sciences of Language, Mythology and Religion (1855-80) .82

Chapter 4

Amidst Mysticism, Subjectivity, and "Decadence": Müller, Linguistics, and the Pan-Turanian Nationalists in the Fin-de-siècle Era

Concluding Thoughts

Bibliography .165 


\section{Preface}

If ever there was an age bent on collecting old things, it is our own. Think only of our museums, brimful of antiquities from all countries and all ages, and which, like our cemeteries, will soon become small villages, if they are to hold all that was once young and alive on earth.... Yet such collections are expensive, and become more so with every year. Then why should not those who are unable to pay for Roman coins or Greek bronzes ... collect antiquities which will cost them nothing, and which are older than the oldest things from any part of the world? The fact is that everybody possesses such a museum of antiquities. Only he does not value it.... That museum is our language. There is no word in English, French, or German, which is not older than the oldest of the pyramids, and yet, while we are willing to pay any sum for a scarabee containing the name of Sesostris, which after all tells us very little, we hardly attach any value to words which, if we would only trace them back to their distant source, might teach us lessons of the highest import.

-Friedrich Max Müller, Biographies of Words and the Home of the Aryas, 1888, p.1-2. 


\section{Introduction}

Among the major scholars of linguistics and Oriental religions in nineteenthcentury Europe, Friedrich Max Müller (1823-1900) stood out as a professor, a prolific editor, a theorist, and a popular lecturer and writer. Though not so widely read from the twentieth century onwards, his books and lectures received much popular attention in his own time. Müller was a German born in the duchy of Dessau and educated at Leipzig in the philologies of Sanskrit, German, and classical Greek and Latin. He was shaped by the German Romantic fascination for the Orient, its past, and its languages. He found his way to England in mid-1846 to edit the manuscripts of the ancient Indian text of the Rigveda, and settled down as a linguistics and philology professor at Oxford. Müller's popularity grew after his linguistics lectures at London's Royal Institution in the 1860s and his supervision of the editing of The Sacred Books of the East series from 1876 onwards. His focus gradually shifted to comparative religion in the context of the Darwinian debates on human evolution from animals. Müller's worries about atheism owing to his Lutheran faith led him to seek for a universal religion through comparative studies of all religions. By the end of his life, he left behind voluminous works on diverse human sciences.

This thesis focuses on one theory Müller developed in the mid-1850s relating to the classification of languages. Building on the discovery of an Indo-European (or "Aryan") language family in the late eighteenth century, he posited the existence of a "Turanian" family of languages spanning Eastern Europe and Asia. This term came from ancient 
Persian texts like the Avesta, which referred to a vague area in Central Asia as "Turan." The nomadic Turkic peoples of this region were the archetypal Turanians. Müller supposed the Turanian group to include most languages there that were non-Aryan, nonSemitic, and non-Chinese. The Turanian languages were Hungarian and the Finnic dialects of Eastern Europe and the Turkic, Mongolic, and Tungusic (Manchu) languages of Northern Asia. In the 1850s, Müller included some Southern Asian languages in the Turanian family, but removed them in the 1890 s in response to criticisms. ${ }^{2}$ Müller was not an expert on these languages as his professional work was on Sanskrit and several modern and classical European languages. He intended to classify the Turanian languages not just for their own sake but to show how the diversity of world languages harmonized with his Christian idea of the monogenesis of all humanity. Right from his early years as an Oxford linguist, Müller popularized this theory in many of his writings and lectures.

Even before Müller's work, the question of linguistic families other than the IndoEuropean one was receiving the attention of European linguists. By the early 1800 s, linguistics had become a predominantly historical discipline emphasizing the empirical and comparative studies of many languages, with the aim of discovering genealogical relationships among them. Many linguists were then inspired by the fervor of nationalist awakenings across Europe to discover the ancestries and close relatives of their own national tongues. Many European nations also had large empires that motivated the collection of facts and knowledge about colonized peoples. Roughly the same time as

\footnotetext{
1 Naval Intelligence Division of Great Britain, A Manual on the Turanians and Pan-Turanianism (Oxford: Oxford University Press, November 1918), 12.

2 Friedrich Max Müller, Natural Religion (London: Longmans, Green, \& Co., 1889), 324.
} 
philologists and linguists uncovered the relationship between Sanskrit and European languages, there arose theories about the family tree of non-Indo-European languages like Hungarian, Finnish, and Turkish. Of the several linguists who worked on this issue, the Finn Matthias Castrén (1813-52) directly preceded Müller in grouping together the Hungarian, Finnic, Turkic, Mongolic, and Tungusic languages into one grand family. Castrén travelled to the Urals and Siberia to study many dialects from native speakers. He named these languages the "Altaic" family after their supposed origin in the Asian Altai mountains. ${ }^{3}$ However, this was already a contested theory with opponents pushing for a smaller Finnic-Hungarian family that was unrelated to Turkish and its Asian relatives.

Müller was like Castrén in favoring a more expansive family of these Eastern European and Asian languages, which he collectively labelled as "Turanian." By the late nineteenth century, some nationalists in Hungary and the Ottoman Empire took up this name to denote the close linguistic and racial relations of the Magyars and Turks. They accepted Castrén and Müller's grouping of languages, and created a Pan-Turanist nationalism that began from the Fin de siècle and reached its peak during World War I. This ideology emerged out of the cultural pessimism about Western civilization in the 1890s and romanticized alternatives like the mobile and militaristic lifestyle of the Eurasian nomads. ${ }^{4}$ The pan-nationalists often had political ambitions of creating a massive Turanian state extending from Hungary to the Pacific Ocean, including all

\footnotetext{
${ }^{3}$ Matthias Alexander Castrén, Ethnologische Vorlesungen über die altaischen Völker nebst samojedischen Märchen und tatarischen Heldensagen, translated into German by Franz Anton Schiefner (St.Petersburg: Buchdruckerei der Kaiserlichen Akademie der Wissenschaften, 1857), 18.

4 Joseph A. Kessler, "Turanism and Pan-Turanism in Hungary 1890-1945" (PhD Diss., University of California, Berkeley, 1967), 1-54.
} 
scattered Turanians. The Pan-Turanists were a fringe force in Hungarian and late Ottoman politics, but became influential during the Great War when the Magyars and Turks were allies. An exotic ideology at first glance, Pan-Turanism sometimes encouraged racial hatred towards other ethnicities and was partly involved in the Armenian genocide during World War I. ${ }^{5}$ This ideology continued even into the twentyfirst century through far-right parties in Hungary and Turkey. Yet in academic linguistics, the Turanian grouping was unsuccessful, losing out to the "Finno-Ugric" theory that Hungarian was related only to the Finnic branch and not to Turkic or Mongolic.

While much historiography on Turanism focuses on the pan-nationalists and their political role in the twentieth century, my thesis turns toward the earlier emergence of the linguistic theory of a Turanian family in nineteenth-century Europe. Max Müller was one of the major popularizers of this theory in Europe, and so this thesis takes a biographical approach to present how this theory related to his broader worldview. The focus is on the methodology and assumptions Müller relied on in fashioning the Turanian identity in the context of nineteenth-century linguistic theories. The broader questions this thesis addresses are how the Turanian theory emerged in the nineteenth century, how European linguists imagined non-Indo-European languages and peoples in this period, and how this linguistic classification theory related to the rise of a Pan-Turanist nationalism in the Austro-Hungarian and Ottoman empires. Relying on a close reading of texts by Müller and Castrén, this is a thesis in intellectual history that traces the history of an idea as it got passed down among nineteenth-century scholars and later influenced popular culture.

\footnotetext{
5 Jacob Landau, Pan-Turkism: From Irredentism to Cooperation (Bloomington, Indiana: Indiana University
} Press, 1995), 54-56. 
This narrative emphasizes the contingency of this theory on contemporary issues then like the stress on uncovering national histories, the imperial context of collecting facts about and ordering the peoples of the world, and specific linguistic theories seen below.

This thesis thus considers Müller's ideas in light of the historical and comparative approach towards studying languages. It shows how the classification of world languages in a hierarchical manner based on their morphologies, i.e. the forms of words, became influential in nineteenth-century linguistics and shaped how European linguists imagined non-Indo-European families like the Turanian one in relation to European languages. The emphasis on morphology began with the German scholars Friedrich and August Schlegel's theories about the "organic" nature of word terminations in the Indo-European family. ${ }^{6}$ These theories rationalized the superiority of Indo-European languages over others, given the dominance of European imperialisms across the world at the time. Embedded in the historical character of linguistics then, such theories lasted until new schools of thought displaced them in the Fin-de-siècle era. The idea of hierarchical morphological classes played a key role in how Müller formulated and justified the existence of a Turanian family of languages. Bringing in civilizational and geological analogies, he even extended the model to his sciences of mythology and religion. While the later Pan-Turanists accepted some of his claims about the existence of a Turanian family, they challenged the superiority of Indo-European languages in these models.

Early-nineteenth-century linguists focused on three major classes of morphology, which they named isolating, agglutinating, and inflectional. As I will explain in chapter 1,

${ }^{6}$ Olga Amsterdamska, Schools of Thought: The Development of Linguistics from Bopp to Saussure (Dordrecht, Holland: D. Reidel Publishing Company, 1987), 37. 
the Turanian languages mostly shared the agglutinating characteristic. Linguists thought of agglutinating languages as those whose words combine root particles expressing meaning with affix particles that do not carry independent semantic significance but show grammatical relations like number, person, gender, case, negation, mood, and tense. An important feature is that the root and affix particles, though connected, remain observable as distinct elements. For example, in the Hungarian word késemnek (kés = knife; -em = my; $n e k=$ to), the root particle kés meaning "knife" adds on two particles -em and -nek that do not stand as independent words. The particles are "glued together" (agglutinated) into one word meaning "to my knife"-which takes up three words in English. Nineteenth-century linguists treated this agglutinating class differently from isolating languages like Chinese in which words were mainly independent roots without affixes. The inflectional class included Indo-European and Semitic languages. Their words too combine roots and affixes like the agglutinating class, but the two elements are so fused together into one mold that they are hard to separate into distinct parts.

It became common in the nineteenth century to weave these three morphological classes into a historical narrative of linguistic change, with isolating languages being the earliest form of all languages and inflectional ones the latest and most advanced. Castrén and Müller both accepted the historical transitions between these classes, and saw the agglutinating Turanian languages occupying the middle stage. Many linguists followed the Schlegel brothers and Franz Bopp in attributing superiority to the extensive inflections of the Indo-European family, while casting Chinese and Turanian languages as primitive. The admiration of inflections found support in German Romantic theories that 
words in a language should ideally express both meaning and grammatical form. ${ }^{7}$ In the early 1800s, linguists often argued that ancient Aryan languages like Sanskrit, Greek, and Latin and their common ancestor best achieved the unity of meaning and form through their extensive inflections. There was also a tendency among linguists to overlap the morphological classes with genealogical families, even when recognizing that likeness in morphology was insufficient to prove descent. Castrén included many agglutinating languages in his "Altaic" family, while adding other reasons for their common descent like shared vocabulary, presence of vowel harmony and postpositions, and ethnological factors like nomadism. Müller went further with the overlapping of morphology and genealogy by placing all agglutinating languages in the "Turanian" family.

This centrality of morphological classification to linguistics declined by the end of the nineteenth century. The younger generation of German linguists in the 1870 s called the Neogrammarians challenged the sweeping claims of earlier linguists_-including Müller's — that languages "progress" from the isolating to inflectional stages. ${ }^{8}$ Influenced by the objectivism of Positivist thought, they rejected normative issues like progress and perfection among languages. They also put aside speculative-sounding metaphors relating languages to organisms that grow, mature, and decay. The Neogrammarians focused on deriving universal laws governing sound shifts in languages based on empirical analyses rather than on acceptance of earlier theories of morphological change. Further changes in linguistics influenced by subjectivist philosophies of the Fin de siècle also sidelined

\footnotetext{
7 Amsterdamska, 41.

8 Joseph Greenberg, Language Typology: A Historical and Analytical Overview (The Hague: Mouton, 1974), 39-41.
} 
morphological classes. In Structuralist linguistics of the early twentieth century, the rigid ordering of languages into "classes" gave way to more flexible "types" that allowed for grouping languages along multiple parameters like sounds, phonemes, syntaxes, and types of historical changes. ${ }^{9}$ The new trends suggested far more ambiguous historical changes in languages than what the unilinear morphological model had predicted.

Although the progressive evolution of languages from the isolating to inflectional classes was no longer a valid theory in academic linguistics after 1900, it played a key role in Müller's works on comparative linguistics and in his formulation of the Turanian theory at Oxford in the 1850s. Müller added various elements to the morphological theories of linguistic change, which led him to the conclusion of a vast Turanian family of agglutinating languages. In the mid-1850s, Müller brought in a civilizational picture of morphological evolution. He related the isolating, agglutinating, and inflectional classes to "family," "tribal nomad," and "state" languages respectively. ${ }^{10}$ This correlation reflected the Romantic influences in his early life that led him to imagine that the social conditions of a people and their languages closely mirrored each other and were both imbued with the Volksgeist. His civilizational metaphor also exuded the mid-Victorian confidence in the progress of the Aryan peoples with advanced states, rule of law, and high culture. Müller associated the Aryan inflectional languages with advanced societies, and created an "other" out of the agglutinating Turanian family and its primitive nomadic

\footnotetext{
9 Greenberg, 42-49.

10 Friedrich Max Müller, "Letter on Turanian Languages," in Christianity and Mankind, vol. III, edited by C. C. J. Bunsen, 1854, 22-26.
} 
way of life. For Müller, one universal set of linguistic methods might not work to genealogically group languages spoken by people from such different social conditions.

Müller's argument for a family of agglutinating languages relied on his assumption that nomadic languages changed differently compared to the Aryan counterparts. In his view, the people in pastoral nomadic societies would experience much dislocation, wars, and chaos as they moved around in tribes searching for pasture for their animals. As these societies might not be able to preserve tradition as well as more settled societies, Müller expected their languages and vocabularies to reflect the chaotic conditions and lose many words and grammatical irregularities over time. ${ }^{11}$ In consequence, languages of nomadic tribes could branch off into unrecognizable dialects within a few generations even if they were of common descent. Hence Müller argued that even closely-related nomadic languages would not resemble each other as the Aryan family. This assumption made him confident about grouping even apparently heterogeneous "nomadic" languages in the Turanian family without rigorous tests for systematic sound shifts as in the Aryan case. Müller treated the "nomadic" civilizational group as an "other" that vaguely consisted of all agglutinating languages — a problematic assumption as he included agglutinating South Asian languages without a clear nomadic history in the Turanian family. ${ }^{12}$

\footnotetext{
11 Müller, “Letter,” 60-70.

12 For recent research on nomadic peoples and their diversity across the world, consult A. M. Khazanov, Nomads and the Outside World, trans. Julia Crookenden (Cambridge: Cambridge University Press, 1983); Thomas J. Barfield, The Nomadic Alternative (Englewood Cliffs, NJ: Prentice Hall, 1993); Nikolay N. Kradin, "Nomadism, Evolution, and World-Systems: Pastoral Societies in Theories of Historical Development," Journal of World-System Research 8 (2002): 368-388; Nikolay N. Kradin, Dmitri M. Bondarenko, and Thomas J. Barfield, eds., Nomadic Pathways in Social Evolution (Moscow: Russian Academy of Sciences, Center for Civilizational and Regional Studies, 2003).
} 
In his essay on the Turanian family, Müller was indebted to the works of the earlier Finnish linguist Castrén who, unlike Müller, had firsthand experiences learning many Eastern European and Northern Asian languages. Both Castrén and Müller saw languages advancing from the isolating to inflectional classes over time, and admired the inflections of the Aryan languages. Even Castrén, whose Finnish nationalism inspired his search for the ancestry of the Finns, accepted the inflectional stage as the highest, and praised the Finnic dialects for possessing the most inflections within the agglutinating Turanian group. ${ }^{13}$ Müller differed from Castrén in several aspects, mainly by insisting that nomadic languages changed far more rapidly than the Aryan ones. Müller consequently put together a lot more heterogeneous languages in his Turanian family than Castrén did in his "Altaic" family. While Müller later renounced his own inclusion of Southern Asian languages in the Turanian family, he also made insightful additions to Castrén's work. Unlike Castrén, Müller repeatedly stressed that linguistic genealogies were distinct from ethnological and racial ones. ${ }^{14}$ This was because languages could be imposed on peoples of other races and customs through conquests and migrations. Castrén, in contrast, vaguely used linguistic resemblances as proof of common descent of actual peoples. Müller did not produce new treatises on the Turanian family after the 1850 s, but this idea figured in his general theories of language, mythology, and religion until late in his life. He pioneered these broad fields owing to their importance in shaping human

\footnotetext{
${ }^{13}$ Castrén, Ethnologische Vorlesungen, 17-18.

14 Müller, “Letter,” 89-93.
} 
nature and in forming the cultural building blocks of nations. ${ }^{15}$ In the nationalist and historicist context of the nineteenth century, Müller hoped to understand human nature by studying the past, often focusing on the etymologies of words. He developed these fields in a comparative and historical direction in the model of physical sciences like geologyinductively collecting facts about phenomena and generalizing about their deeper nature. ${ }^{16} \mathrm{He}$ infused a strong Protestant religious outlook into his construction of these human sciences, trying to deduce divinely-ordained laws in the process. Intending to develop comparative sciences, Müller added geological metaphors to the morphological evolution of languages from isolating to inflectional classes alongside the earlier civilizational metaphors. This was after a geological field trip in 1855 , which inspired him to think of layers or "strata" of sedimentary rocks deposited by the water flow in different geological eras as analogous to historical changes in language morphology.

In Müller's famous lectures on the science of language in the 1860s, he presented the Turanian family as an intermediary agglutinating "stratum" in the course of linguistic evolution towards inflectional languages. The metaphor of geological strata rhetorically helped Müller showcase this theory as a part of his comparative science. He argued for including the nomadic stratum of languages in linguistic studies, claiming that the literature-rich Aryan and Semitic languages were "artificially domesticated" and failed to illuminate the natural earlier evolution of human speech. ${ }^{17}$ While Müller clearly treated

\footnotetext{
${ }^{15}$ Max Müller, Lectures on the Science of Religion (New York: Scribner, Armstrong, \& Co., 1872), 84-88.

${ }^{16}$ Max Müller, Lectures on the Science of Language Delivered at the Royal Institution of Great Britain in 1861 and 1863, vol. 1 (New York: Scribner, Armstrong, \& Co., 1873), 24-31.

17 Max Müller, On the Stratification of Language (London: Longmans, Green, Reader, and Dyer, 1868), 910.
} 
the inflectional stratum as the most advanced, his broader worldview suggests that he was not entirely unsympathetic towards speakers of other primitive languages. For Müller, all languages were intimately connected to the ability to think rationally — a faculty he found to be shared by all human races and lacked by animals. This idea came from his Christian universalism that all humans shared divine grace, and from a Romantic reverence for the complexity of the earliest human states. His idea of a linguistic chasm between humans and animals and his opposition to Darwinian human evolution led to bitter attacks from Darwinians, but tied all human languages into a closely-related category in his thought.

There were similar references to stratification in Müller's historical sciences of mythology and religion, which he thought of as evolving in stages. Müller hypothesized a temporary regressive stage after the origin of language wherein human cultures produced myths involving fantastic stories about divine, magical, and heroic characters. In an era privileging scientific facts, progress, and historical criticism of texts, he found such narratives to be irrational superstitions caused by a "disease of language" - a backward step before humans progressed to higher religion and philosophy. ${ }^{18}$ Myths were a linguistic disease in that they were originally rational anthropomorphic metaphors for natural events that later generations of people mistakenly interpreted in a literal manner. For instance, the metaphor of a human hand to describe the sun's rays might yield myths — generations later—about the sun god having many hands. The misperception supposedly stemmed from changes in language as the originally isolating languages lost the clear meaning of their independent roots. Müller expected all cultures to pass through

\footnotetext{
18 Max Müller, Lectures on the Science of Language Delivered at the Royal Institution of Great Britain in 1861 and 1863, vol. 2 (New York: Scribner, Armstrong, \& Co., 1873), 376-399.
} 
the mythological stratum at some point in history, but saw inflectional language speakers as more successful in breaking free from the mythological illusion early on.

In the last decades of his life, Müller concentrated mostly on comparative religion by being part of the editorial process of the Sacred Books of the East series and by his lectures and writings. Trying to defend his own Christian faith during the Darwinian debates, Müller claimed that comparing all religions, instead of asserting the dogmas of one's own, was best to comprehend religion in general. A Pietistic Lutheran, Müller viewed outward ritualistic and social aspects of religion as superficial, preferring instead personal connection to God. Despite attacks from hardline theologians, he was critical of Christian beliefs in miracles, and saw some Biblical claims like the Virgin birth of Jesus and his bodily resurrection as resembling exaggerated myths in other religions. ${ }^{19} \mathrm{He}$ argued based on comparing mainly Aryan and Semitic religions that religions had rational origins in human contemplations of nature. Instead of relying on God's self-revelation, humans had to work towards the concepts of God and the soul through rational inquiry beginning from a "perception of the infinite" beyond the observable world. Their questioning of the agency behind nature led them through stages like myths, henotheism, and polytheism before eventually arriving at monotheism. ${ }^{20}$ Müller held that the ideas of one God and the soul were most advanced, and in the 1890s, turned to a mystical panentheistic stage of oneness of God and the soul as the highest religion. As with languages, he placed "Aryan" traditions like Indian Vedantism and Neoplatonism in this

\footnotetext{
19 Max Müller, Anthropological Religion (London: Longmans, Green, \& Co., 1892), vii-xx.

${ }^{20}$ Max Müller, Lectures on the Origin and Growth of Religion, as Illustrated by the Religions of India (London: Longmans, Green, \& Co., 1879), 260-315.
} 
highest mysticism, but also argued for including Christianity. For Müller, the "Aryan" idea of "logos" in Greek thought inspired early Christians to imagine God and human souls united through the incarnation of God's Word (Jesus Christ or logos). ${ }^{21}$ In contrast, the native Turanian religions were bookless and shamanistic and had multiple competing ancestral and nature spirits. Müller saw them as more primitive than the monotheistic stratum, but, given his universalism, respected them too for containing some truths. Müller's postulation of the Turanian theory and his inclusion of this theory in his human sciences influenced the Pan-Turanist nationalists during the Fin de siècle. ${ }^{22}$ One significant shift in moving from Müller's theory to the pan-nationalists was that the latter challenged Müller on the superiority of Aryan languages and speakers. As a variant of Magyar and Turkish nationalisms that extended the shared feeling of national oneness to all Turanians, Pan-Turanism encouraged pride in the greatness of the native traditions of Uralo-Altaic peoples—often in opposition to the West. It drew on the pessimistic cultural mood in Europe during the Fin de siècle, which involved fears of degeneration and weakening of the West. This promoted positive representations of non-Western nomadic cultures, sometimes to the extent of directing racial hatred towards the West and other non-Turanians. Pan-Turanism in Hungary emerged in the 1890s, after a linguistic debate

\footnotetext{
${ }^{21}$ Max Müller, Theosophy, or Psychological Religion (London: Longmans, Green, \& Co., 1893), 506-526.

${ }^{22}$ Apart from the contributions of Joseph Kessler and Jacob Landau cited here, the following works also discuss Pan-Turanism in depth: Hugh Poulton, Top Hat, Grey Wolf, and Crescent: Turkish Nationalism and the Turkish Republic (London, England: Hurst, 1997); Alaattin Oguz, "The Interplay between Turkish and Hungarian Nationalism: Ottoman Pan-Turkism and Hungarian Turanism (1890-1918)," MS Diss., The Middle East Technical University, 2005; Judith Winternitz, "The 'Turanian' Hypothesis and Magyar Nationalism in the Nineteenth Century," in Culture and Nationalism in the Nineteenth-Century Eastern Europe, eds. Roland Sussex \& J. C. Eade (Ohio: Slavica Publishers, 1985); Serge A. Zenkovsky, PanTurkism and Islam in Russia (Cambridge, MA: Harvard University Press, 1960); George Arnakis, "Turanism: An Aspect of Turkish Nationalism," Balkan Studies 1 (1960): 19-32. Also consult Arthur Anthony Macdonell, "Pan-Turanianism," Encyclopedia Britannica (12th ed.).
} 
called the "Ugric-Turkic battle" in the 1870s. In these debates, Arminius Vambéry, the famous Hungarian explorer of Central Asia in disguise, was among those who placed the Magyar language in the Turanian family. While it began as a linguistic pan-nationalism, Pan-Turanism spread to fields beyond linguistics like ethnology, history, geography, art history, and poetry in Hungary and the Ottoman Empire. It led to the confused overlapping of racial and ethnic interpretations of the Turanian identity on its linguistic origins. ${ }^{23}$ This happened despite Müller's cautions that the Turanian family was a purely linguistic one, suggesting the complexity of the transfer of his ideas to the cultural realm.

To present the development of the morphological classification theory and its impacts on Müller's Turanian grouping and the Pan-Turanist nationalists, this thesis includes four chronological chapters from 1800 to 1918 . Chapter 1 covers the period before the 1850s when European linguists before Müller were establishing genealogical links among languages and creating morphological classes with ideas of progress and decay. It focuses on Castrén as a predecessor of Müller and his use of agglutination and some ethnological similarities in grouping together a large "Altaic" family. Chapter 2 transitions to Müller in the 1850 s and his couple of essays detailing his linguistic classification that included the Turanian family. As a young linguist at Oxford, Müller added civilizational elements to morphology and questioned the use of universal methods for nomadic and state languages, creating an "other" out of the agglutinating languages. Then, the broader comparative sciences Müller developed and publicized in the 1860s and ' 70 s form the subject of chapter 3 . His geological metaphors to evoke parallels to the

\footnotetext{
${ }^{23}$ Kessler, "Turanism and Pan-Turanism in Hungary 1890-1945," 71.
} 
physical sciences and his disagreements with the Darwinists shaped his turn to general theories of language and religion. His view of the Turanian family retaining the features of an earlier, more primitive condition of the Aryan family pervaded his sciences. Chapter 4 concludes the narrative by focusing on Müller's late years during the Fin de siècle and the rise of Pan-Turanist movements until World War I. Following some critiques, Müller gave up identifying some Southern Asian languages as Turanian, but retained his optimistic evolutionary views. This chapter covers the rise of subjectivism, mysticism, and cultural pessimism during the Fin de siècle and their lead up to Pan-Turanism.

The principal primary sources for this thesis are Müller's published essays, lectures, and biographical material. While his published works are themselves numerous and voluminous, Müller also left behind a huge corpus of unpublished manuscripts that are now kept in Oxford's Bodleian Library. Unfortunately, this thesis does not incorporate the latter material. His two essays on the Turanian family and his classification scheme inform the central narrative here. They were the "Letter on Turanian Languages" (1854) and The Languages of the Seat of War in the East (1855). Müller wrote the former to show how the diversity of languages might harmonize with the Christian theological idea of the monogenesis of all humans, while he composed the latter at the request of the British government during the Crimean War to make British officers aware of the languages of Eastern Europe and the Russian Empire. Besides these texts, Müller referred to the Turanian group in his famous Lectures on the Science of Language in 1861 and '63, in his 1868 article "On the Stratification of Language," and in his lectures on religion in 1871, 1878 (the Hibbert Lectures), and 1889-93 (the Gifford Lectures). As Müller was 
a Sanskritist by training, the Turanian theory was quite peripheral to his thought, but this thesis surveys his broader writings to better contextualize this theory.

Apart from Müller's works, my thesis also relies on primary material by the PanTuranists and some relevant linguists. As Castrén's fieldwork and "Altaic" theory influenced Müller's Turanian theory, this thesis considers Castrén's published works. His writings were in Finnish and Swedish, but I used the German translations by his friend Anton Schiefner in the 1850s. Castrén's works included travel memoirs to Lapland, the Urals, and Siberia, and grammars and folklore collections of the supposed relatives of the Finns. Of these, his lecture series late in life relating various "Altaic" peoples illuminated well his thoughts about Finnish genealogy. Also, regarding the Pan-Turanists in Fin-desiècle Hungary and the Ottoman Empire, this thesis uses published Anglophone texts including those by the Jewish-Hungarian nationalist and linguist Vambéry, the Turanist poet Arpád Zempléni, and the American White supremacist Lothrop Stoddard, and the British navy's details on Pan-Turanism just after World War I. ${ }^{24}$ These sources are not comprehensive as there is a large volume of untranslated material in Hungarian and Turkish by the pan-nationalists. For this reason, this thesis focuses on Müller's perspective and only briefly covers his legacy inspiring Pan-Turanism in chapter 4.

Historiographically, Max Müller' life received sparse attention in the twentieth century, but there has been a revival of interest over the last few decades. His theories

\footnotetext{
24 Some of these primary texts are Arminius Vambéry, Arminius Vambery: His Life and Adventures (London: T. Fischer Unwin, 1889); Árpád Zempléni, Turanian Songs: Legendary and Historical HeroSongs (Budapest, New York: Franklin Society, 1916); Lothrop T. Stoddard, "Pan-Turanism," The American Political Science Review 11, no. 1 (1917): 12-23; A. J. Toynbee, Report on the Pan-Turanian Movement (London: Intelligence Bureau Department of Information, Admiralty, L/MIL/17/16/23, 1917); Naval Intelligence Division, A Manual on the Turanians and Pan-Turanianism; and Great Britain Foreign Office, The Rise of the Turks: The Pan-Turanian Movement (The British Foreign Office, 1919).
} 
bore the nineteenth-century stamp of evolutionary progress that lost influence in the pessimistic era of world wars with the rise of new schools of thought. However, Müller's key role in the Europe-wide network of scholars in the nineteenth century has attracted recent scholars studying his era. An early biography in 1974 by the Indian novelist Nirad Chaudhuri related Müller's personal story to his intellectual efforts, but focused on his passion for India and Sanskrit studies and his connections to Indian religious reformers. Then came more specialized essays on Müller's comparative religion by Garry Trompf (1978), on his linguistics by Kurt Jankowski (1979), on his Rigveda editions by Ronald Neufeldt (1980), on his debates with Darwin by Elizabeth Knoll (1986), on his Indology by Herman Tull (1991), and on mythology by Ivan Strenski (1996). ${ }^{25}$ A major monograph by Lourens van den Bosch was published in 2002 uniting Müller's theories of language, mythology, and religion to give a holistic picture. Also, Jon Stone published a collection of sources by Müller in a 2002 volume entitled The Essential Max Müller.

The monographs by Chaudhuri and Bosch and the shorter articles have added much to our knowledge of Müller's ideas. Still, the diverse nature of Müller's activities such as his editorial and curatorial work, his contributions to the public press, his contacts with

\footnotetext{
25 These specialized secondary sources on Müller covering specific aspects of his thought include Garry W. Trompf, Friedrich Max Müller: As a Theorist of Comparative Religion (Bombay: Shakuntala Publishing House, 1978); Kurt R. Jankowski, "F. Max Müller and the Development of Linguistic Science," Historiographica Linguistica 6 (1979): 339-59; Ronald W. Neufeldt, Friedrich Max Müller and the Rigveda: A Study of its Role in his Work and Thought (Calcutta, 1980); K. A. Manley, "Max Müller and the Bodleian Sub-librarianship, 1865," Library History, vol. V (1981): 33-47; Joseph M. Kitagawa and John S. Strong, "Friedrich Max Müller and the Comparative Study of Religion," in Nineteenth Century Religious Thought in the West (vol. 3), eds. Ninian Smart, John Clayton, Stephen Katz, and Patrick Sherry (Cambridge: Cambridge University Press, 1985), 179-213; Elizabeth Knoll, "The Science of Language and the Evolution of Mind: Max Müller's Quarrel with Darwinism," Journal of the History of the Behavioral Sciences 22 (1986): 3-22; Herman Tull, "F. Max Müller and A. B. Keith: 'Twaddle,' the 'Stupid' Myth, and the Disease of Indology," Numen 38 (June, 1991): 27-58; and Ivan Strenski, "The Rise of Ritual and the Hegemony of Myth: Sylvan Lévi, the Durkheimians, and Max Müller," in Myth and Method, eds. Laurie L. Patton and Wendy Doniger (Charlottesville: University of Virginia Press, 1996), 52-81.
} 
leading politicians and intellectuals, and his numerous lectures has made it challenging for scholars to cover every aspect of his life. Müller's Turanian theory was one of his concerns that has hitherto not received recent scholarly attention, particularly the theory's relation to the Pan-Turanists. There were two recent conferences on Müller's works that dealt with his other texts on Asian religions and general philology. The conference at Heidelberg in 2014 was called "Friedrich Max Müller and his Asian Interlocutors." It discussed Müller's big project in his later years of leading a team to translate fifty volumes of "sacred" books of the Orient, and his interactions with Asian scholars. The other conference was at London's German Historical Institute in 2015 on his impact on Victorian thought. ${ }^{26}$ Here, scholars discussed the intellectual networks linking Müller with fellow Victorians, and some nuances on his theories. Participants in this conference like Arie Molendijk and Thomas Green published their own books in 2016 on Müller's Sacred Books and on the impact of Eastern religions on his own views respectively.

As my thesis discusses Müller's Turanian theory in relation to nineteenth-century linguistics and Pan-Turanist nationalism, it builds on and links the historiographies of these issues. Prominent histories of language studies of this era include Hans Aarsleff's 1982 text on intellectuals from John Locke to Ferdinand de Saussure, and Olga

\footnotetext{
26 The 2015 London conference papers are published in John R. Davis and Angus Nicholls, eds., Friedrich Max Müller and the Role of Philology in Victorian Thought (London: Routledge, forthcoming in 2018). Other more recent sources on Müller are Patricia Casey Sutcliffe, "Friedrich Max Müller and William Dwight Whitney as Exporters of Nineteenth-Century German Philology: A Sociological Analysis of the Development of their Linguistic Theories," PhD Diss., University of Texas at Austin, 2000; Norman Girardot, "Max Müller's Sacred Books and the Nineteenth-Century Production of the Comparative Science of Religion," History of Religions 41 (February 2002): 213-250; Max Müller, The Essential Max Müller: On Language, Mythology, and Religion, ed. Jon R. Stone (New York: Palgrave, Macmillan, 2002); Arie Molendijk, Friedrich Max Müller and the Sacred Books of the East (Oxford: Oxford University Press, 2016); and Thomas J. Green, Religion for a Secular Age: Max Müller, Swami Vivekananda, and Vedanta (London: Routledge, 2016).
} 
Amsterdamska's 1987 analysis of the institutional changes in linguistics through the century. More recent works are Stephen Alter's 1999 publication linking linguistics to the natural sciences and the Darwinian debates, and Tuska Benes's 2008 book positing the influence nineteenth-century theories of language had on Postmodernism. ${ }^{27}$ Still, the links between these linguistic theories and the Pan-Turanists have not yet been fully explored. The literature on Pan-Turanism mostly focuses on the Fin de siècle and twentieth century when the pan-nationalists emerged in the politics of Hungary and the Ottoman Empire. Some histories of this movement are Joseph Kessler's intellectual and political history of the Magyar Turanian Society in Budapest from 1890 to 1945, Jacob Landau's analysis of Pan-Turkism in twentieth-century Turkey, and Hugh Poulton's history of the varieties of Turkish nationalisms like the religious, ethnolinguistic, Turanist, and Anatolian alternatives. My thesis shows how earlier linguistic ideas informed the Pan-Turanists, who then challenged the superiority of Indo-European languages in the earlier models.

\footnotetext{
${ }^{27}$ For a broader discussion of the history and historiography of linguistics in the nineteenth century, consult Hans Aarsleff, The Study of Language in England, 1780-1860 (Princeton, NJ: Princeton University Press, 1967) and From Locke to Saussure: Essays on the Study of Language and Intellectual History (Minneapolis: University of Minnesota Press, 1982); Tuska Benes, In Babel's Shadow: Language, Philology, and the Nation in Nineteenth-Century Germany (Detroit, MI: Wayne State University Press, 2008); and Umberto Eco, The Search for the Perfect Language, trans. James Fentress (Oxford: Basil Blackwell, 1995). The general intellectual history of the nineteenth century and of some human sciences is covered in John W. Burrow, The Crisis of Reason: European Thought 1848-1914 (New Haven: Yale University Press, 2000); Richard G. Olson, Science and Scientism in Nineteenth-Century Europe (Urbana and Chicago: University of Illinois Press, 2008); James A. Winders, European Culture since 1848: From Modern to Postmodern and Beyond (New York: Palgrave, 2001); George W. Stocking Jr. Victorian Anthropology (New York: The Free Press, 1987); Eric Sharpe, Comparative Religion: A History (New York: Charles Scribner's Sons, 1975); Edward Said, Orientalism (New York: Vintage Books, 1979); and David Blackbourn, The Long Nineteenth Century: A History of Germany 1780-1918 (New York: Oxford University Press, 1997).
} 


\section{CHAPTER 1 \\ The Idea of a Turanian Language Family in Early-Nineteenth-Century Linguistics}

But a new era in the history of Turanian philology begins with one who, though in delicate health, left his study, traveled for years alone in his sledge through the snowy deserts of Siberia, coasted along the borders of the Polar Sea, lived for whole winters in caves of ice or in the smoky huts of greasy Samoïeds, then braved the sand-clouds of Mongolia, passed the Baikal, and returned ... to his duties as Professor at Helsingfors - to die, after he had given to the world but a few specimens of his treasures. This heroic grammarian was Alexander Castrén.

—Max Müller, "Letter on Turanian Languages," 1854, p.14.

Many European linguists carrying out research in the early nineteenth century showed an interest in understanding the historical and genealogical relationships among different languages of the world. Their counterparts from earlier centuries had made scattered, though considerable, speculations on the relationships among various European and world languages. Scholars in early modern times had already worked out the grouping of European languages into Germanic, Romance, Hellenic, Slavic, and Celtic branches and their common ancestry. ${ }^{28}$ Several factors converged in the early nineteenth century to more intensely focus the study of language on historical and comparative linguistics. The British Orientalist William Jones's popularization of the relation between Sanskrit and European languages after 1786 and the rise of nationalist sentiments across Europe during the Napoleonic Wars promoted curiosity among scholars about the place of each language in history. The spread of European empires overseas helped in the collection of more data on exotic foreign languages, and professionalization of linguists in universities promoted systematic studies on a common theme like historical linguistics.

28 Robert H. Robins, A Short History of Linguistics (London: Longman Group, 1990), 181-85. 
It was in this context of linguistic research that scholars sought to understand the ancestries of languages other than the newly-uncovered Indo-European family. The most advanced research in linguistics at the time was carried out in German universities by scholars like Franz Bopp, Jacob Grimm, and August Pott. Many of them focused on the genealogical study of Indo-European languages, given their own nationalistic and romantic interests in the German language - which belonged to the Indo-European family. However, there were several German and other European linguists in the early nineteenth century who tried to determine the genealogical classification of remaining European languages like Hungarian, Finnish, Estonian, Lapp, and their numerous relatives. They reached widely varying conclusions about the relationships of these languages to Asian languages of the Turkic, Mongolic, and Manchu branches..$^{29}$ They all might not have used the term "Turanian" family to express the relationship among these languages, especially as there were alternative names like "Altaic," "Tataric," or even "Scythian" in usage. Yet the idea of a large family of these European and Asian languages and their loose association with the name "Turanian" were in circulation.

This chapter focuses on the period before Max Müller wrote about his Turanian theory at Oxford in the 1850s. Prior to him, linguists like Sámuel Gyarmathi, Julius Klaproth, Rasmus Rask, and Matthias Castrén had already tried to classify the Turanian languages. As my first quote suggests, the Finnish linguist Castrén published influential texts on the Turanian languages in the 1840s based on first-hand experiences in Siberia. His grouping of Finnic, Turkic, Samoïedic, Mongolic, and Manchu languages into an

\footnotetext{
29 Müller, "Letter," 10-21.
} 
"Altaic" family set up Müller's Turanian theory. How and why did such research on the so-called Turanian language family emerge at this time? One theme is the widely-held emphasis on studying languages historically to discover their ancestries. Linguists then also classified languages based on morphologies (word-formation patterns) into classes like isolating, agglutinating, and inflectional languages, fitting these groups into grand historical narratives of linguistic change. In the imperialist context of the age, they often stressed the superiority of inflectional Indo-European languages. Many scholars saw such morphological classes as distinct from genealogies. Yet, as Turanian languages were often agglutinating, some linguists like Castrén suspected their common descent, while others disputed it. Castrén defended his theory by noting similarities among words in Turanian languages. He also saw shared ethnological customs like nomadism, shamanism, and marriage rites uniting this large family. Though a nationalist sympathetic to the presumed Asian relatives of the Finns, he followed the idea of inflection being the most advanced stage and claimed that the Finnic dialects were progressing towards this end. The last part of this chapter details Castrén's life and his “Altaic” theory given his influence on Müller.

\section{Historical Linguistics and the Classification of Languages}

Long before the nineteenth century, scholars in Europe had already begun the historical study of languages by analyzing their changes over time. Though it is an oversimplification to assign any one era as the absolute beginning, some Renaissance-era scholars made efforts in this direction. ${ }^{30}$ The historian of linguistics Robert H. Robins stresses the rising status of vernacular modern European languages in relation to classical

\footnotetext{
${ }^{30}$ Robins, A Short History of Linguistics, 114.
} 
Latin owing to the growth of centralized early-modern nation-states. As the invention of printing encouraged the production of texts in the increasingly standardized forms of vernacular languages, the relationship of modern languages to classical Latin and Greek came to interest scholars. The revival of classical learning through the exegesis of original texts from antiquity also helped scholars pay attention to changes in languages over time and their causes. For Robins, Dante Alighieri's fourteenth-century classification of European languages into Germanic, Latin, and Greek families based on important words like affirmative particles exemplified the genealogical thinking of his time. ${ }^{31}$ Quite often then, many scholars saw Hebrew as the original mother of all languages.

In addition to the greater attention to modern languages, early modern Europeans were exposed to an enormous variety of exotic foreign languages through their colonies, trade, and missionaries. They were aware that languages like Chinese did not have the declensions and conjugations that Latin had, and instead used morphemic-syllabic characters and tone changes to convey meaning. The wide differences from Latin raised new questions about the relations among world languages and their origins. The Biblical monogenesis view of languages continued to have followers like the seventeenth-century philosopher Gottfried Wilhelm Leibniz. However, Leibniz rejected the idea of Hebrew as the original language of humanity before Babel, claiming the difficulty of deriving Latin roots from the trilateral ones of Hebrew. ${ }^{32}$ Hebrew roots tended to have three consonants (hence the name trilateral) as opposed to two or less in Latin. He argued for a northern

\footnotetext{
${ }^{31}$ Robins, 181.

32 Robins, 184.
} 
Kelto-Scythian and southern Aramaic language group, placing European languages in the southern group. Leibniz's categories reflected the expansion of European knowledge about non-European languages, and he even posited a relation between Hungarian and Finnish. In all this, a historical consciousness continued in the study of languages.

In order to tackle the diversity of world languages, the methodology of historical linguistics work became more sophisticated by the late eighteenth century. Scholars in the sixteenth century like Joseph J. Scaliger had continued the practice of labeling families on the basis of a single word — like the word for God—into Theos, Deus, Godt, and Boge languages. ${ }^{33}$ While this approach might have led them to miss seeing all the Romance, Germanic, and Slavic languages as themselves forming a larger family, others like the Swede Georg Stiernhelm compared the conjugations of Gothic and Latin to deduce their relationship. Europeans were thus becoming more aware that their own languages were mostly closely related. Compilations of comparative word lists, grammars, linguistic atlases, and translations of the Bible into foreign languages went closely with linguistic study at the time. ${ }^{34}$ In addition to the empirical work, a more speculative set of theories on the origin and history of languages emerged in the eighteenth century. Philosophers like Condillac, Rousseau, and Herder exemplified this trend with their claims of languages originating in gestures or some primitive abstracting capacity. Such writings on the prehistory of languages did not disappear even in the empirical mood after 1800 .

\footnotetext{
${ }^{33}$ Robins, 183.

${ }^{34}$ Robins, 184.
} 
While historical thinking was not something new in linguistics given all this earlier work, it was only in the nineteenth century that historical and comparative linguistics became a dominant tradition in the field. Most linguists who did advanced research followed the historical approach. This unique pattern of diachronic studies, which set apart the nineteenth century from earlier and later periods, emerged in the German states following the newly-uncovered linguistic relationship between Sanskrit and European languages like Greek, Latin, Gothic, and others. The ideology of German Romanticism that was dominant early in the nineteenth century idealized and celebrated the ancient world of the Orient, and tried to relate the German nationality to its supposed Oriental origins. Words like indogermanisch and Indo-European can be traced to their earliest usages in the 1810s-20s, suggesting the common descent of Europeans and IndoIranians. ${ }^{35}$ Much linguistic research in this era went into reconstructing the ancestral mother tongue of these peoples, and specifying the processes of grammatical change from its origins to the present. Sanskrit became central to German linguistics, as linguists now understood Sanskrit and most European languages to belong to the same family.

In the search for understanding the origins and history of Indo-European languages, the study of grammatical structures like sounds, word structures, conjugations, and declensions took center stage. There was an empirical emphasis on drawing conclusions based on observing existing languages. Yet it went alongside Romantic notions of a onceperfect highly-inflected ancient Indo-European mother language from which modern languages have decayed. The more numerous inflections in classical languages like

35 Robins, 188. 
Sanskrit and Latin than modern languages like French and English supported the idea of linguistic decay. Tracing changes in languages from ancient to modern times, linguists discovered general patterns of sound shifts. Drawing on their discovery by the Danish linguist Rasmus Rask, Jacob Grimm showed systematic consonantal shifts from Greek to Gothic to Old High German. These shifts (later called Grimm's Law) became important to prove genealogical relationships among languages. Other German linguists like Franz Bopp tried to reconstruct the original Indo-European by comparing the conjugations of its daughter languages. Two decades later, in the 1840s, a younger linguist named August Schleicher developed his Stammbaumtheorie, fitting all Indo-European languages into a genealogical tree diagram with a common source and many branches.

In this period of genealogically grouping languages, another classification of languages into isolating, agglutinating, and inflectional classes based on morphologies (i.e word-formation) became influential. As one recurring idea in the Turanian theory was agglutination, a clarification of this terminology could be helpful. Nineteenth-century linguists interpreted the morphological classes slightly differently based on their specific world-views. In general, however, isolating languages are those whose words are mostly single roots. ${ }^{36}$ These words do not carry affixes expressing functions like person, gender, number, case, tense, and mood. Instead, such functions are expressed by separate words as in the Chinese past tense marker "le" written after verbs like "xie̋" (write) to form "xiě $l e$ " (wrote). Agglutinating languages like Turkish, in contrast, have many words formed by combining the roots with several affixes, each of which would indicate a specific

\footnotetext{
36 William O'Grady and John Archibald, Contemporary Linguistics: An Introduction (Boston: Bedford/St. Martin's, 2010), 310.
} 
grammatical category. ${ }^{37}$ The Turkish word "sev-me-mek" (not to love) negates the verb "sev-mek" (to love) by combining the infix "-me-" and root. The infix indicates negation here. Finally, inflectional languages combine roots and affixes as well but one affix might simultaneously denote several grammatical categories. ${ }^{38}$ A highly inflected language like Latin has nouns like "aquam" (water), where the declension "-am" denotes two relations like the accusative case and singular object at the same time. Linguists during $1800-50$ often held an idea that inflectional affixes were fused into a unity with the root.

Nineteenth-century linguists mostly treated these classes distinctly from genealogy, with the latter requiring proofs of systematic sound shifts as well. Many German linguists like Bopp, Wilhelm von Humboldt, and Schleicher worked on morphology, but its earliest proponents were the Early Romantics Friedrich Schlegel and his brother August. They based their division of languages into inflectional, agglutinating, and isolating ones on their sense that the inflectional Indo-European languages were like organisms with an inner life-force. ${ }^{39}$ Dividing words into parts that express meaning (roots) and those that express relations (inflections), they saw the ancient Indo-European languages exhibiting the perfect union of roots and inflections into an organic whole. The brothers interpreted the elaborate conjugation systems of these languages as having roots that were "living and productive germs" and blossomed forth the inflections by "unfolding from within." 40

\footnotetext{
37 O’Grady and Archibald, 311.

38 O’Grady and Archibald, 311.

39 Olga Amsterdamska, Schools of Thought: The Development of Linguistics from Bopp to Saussure (Dordrecht, Holland: D. Reidel Publishing Company, 1987), 37.

40 Amsterdamska, 39, 40.
} 
Inflections of the German verb "sprechen" (to speak) like "spricht" and "sprachst" exemplified internal changes to the root "sprech-." The Schlegels analogized these roots producing inflections to plant-stems growing organically and blooming into flowers and fruits. Seeing organic internal changes and the union of form and meaning as the nature of Indo-European languages, the brothers eulogized them while denigrating agglutinating languages with affixes added to fixed roots as too mechanical. Friedrich Schlegel wrote:

In the Indian and Greek languages each root is actually that which bears the signification, and thus seems like a living and productive germ, every modification of circumstance or degree being produced by internal changes; freer scope is given to its development, and its rich productiveness is in truth almost illimitable.... Those languages, on the contrary, in which the declensions are formed by supplementary particles ... have no such bond of union: their roots present us with no living productive germ, but seem like an agglomeration of atoms, easily dispersed and scattered by every casual breath.... Its apparent richness is in truth utter poverty, and languages belonging to that branch, whether rude or carefully constructed, are invariably heavy, perplexed, and often singularly subjective and defective. ${ }^{41}$

These morphological classes figured in grand narratives of linguistic change, given the historicism of this age. The Schlegels saw only inflectional Indo-European languages as organisms capable of innate growth towards perfection, while mechanical languages need an external push to come out of stagnation. ${ }^{42}$ In their grouping, isolating languages were ones like Chinese lacking inflections and having merely mono-morphemic roots for words. Agglutinating languages were exemplified by Turanian languages like Turkish with distinct (though connected) roots and affixes. The inflectional Indo-European group, in contrast, fuses the roots and affixes into an organic whole. For the Schlegels, these

\footnotetext{
${ }^{41}$ Friedrich Schlegel, "On the Language and Wisdom of the Indians," in The Aesthetic and Miscellaneous Works of Friedrich von Schlegel, trans. Ellen J. Millington (London: Henry G. Bohn, 1849), 449-450.

42 Amsterdamska, 40.
} 
categories appeared to be fixed essences and languages did not transition from one class to another over time. They saw inflectional languages as never having had an earlier stage where they showed agglutinating characteristics. One problem with the Schlegels' categories is that they were too essentialist. In reality, a formerly inflected language like English could shed its inflections and become more isolating. Yet the Schlegels' view of growth and maturity of organic languages paved the way for later theories.

The linguist Bopp challenged the Schlegels' dichotomization of languages into inflectional and agglutinating, and instead proposed an agglutination theory of the origin of inflections. Bopp himself had adopted the Schlegels' view in his 1816 book comparing the conjugations of Indo-European languages ${ }^{43} \mathrm{He}$ initially viewed the inflections as produced by organic internal modifications of roots. However, by 1819 , he came to the idea that inflectional languages today must have emerged from a former agglutination, and that the inflectional endings of words today once had a clear meaning in the IndoEuropean ancestor. Bopp claimed that etymologies of Gothic preterite inflections, Latin futures, and Greek aorist endings revealed that the inflections were earlier independent verbs like "to do" or "to be." "44 These verbs were initially affixed to roots and gradually lost their independent meaning through phonetic decay. Still, despite breaking the wall between agglutination and inflection, Bopp held that ancient Indo-European was the most perfect organic language that unified form and meaning. ${ }^{45}$ This was a different sense of

\footnotetext{
43 Amsterdamska, 41.

44 Robins, 191.

45 Amsterdamska, 41.
} 
organic from the Schlegels, as Bopp stressed how every root and affix in this original language had both a transparent meaning and played a clear formal role in a sentence.

Bopp's agglutination theory was a significant shift from the Schlegels' theory of organic and mechanical languages, as Bopp opened up the possibility of inflectional languages not always having had such inflections. This approach allowed for historical evolution from the isolating to the inflectional stage with the agglutinating stage in the middle. Nevertheless, Bopp followed the Schlegels in assigning normative values like perfection and decay to different stages of morphology. He admired the supposed transparent inflections of the original Indo-European language - even though they were derived from earlier agglutination — and perhaps did not see any other family of languages as having reached such perfection. He was particularly critical of isolating languages like Chinese for their supposed inability to express all possible grammatical relations in the absence of inflections ${ }^{46}$ This was a pervasive attitude in early-nineteenthcentury German linguistics towards isolating languages. Linguists often imagined Sanskrit and Chinese as polar opposites with the former embodying the near-perfection of its conjugations and declensions. Variants of both the Schlegels' and Bopp's views of inflections and their admiration for inflecting languages would recur in later linguistics.

One linguist who brought together some aspects of the Schlegels' and Bopp's theories was Humboldt in his Über das Entstehen der grammatischen Formen (1822). Unlike Bopp, he did not explicitly claim that languages change from the agglutinating to inflectional stages. Yet he subtly presented languages moving from a material origin to

\footnotetext{
46 Amsterdamska, 41.
} 
the highest stage where all words expressing meaning also convey grammatical form. ${ }^{47}$ The first stage is isolating languages whose words have just material connection to worldly things and lack formal sense. To convey relations like case, gender, mood, and tense, these languages have to change word positions in sentences. As languages grow further, they tend to fix word positions and express formal relations through some words acquiring a purely formal character (affixes). These affixes are then joined to the roots in agglutinating languages, where the divide between roots and affixes is still visible. Over time, in the advanced inflectional stage, the two become united and every word represents both form and meaning. Humboldt continued seeing classical Indo-European and Chinese as opposites, but still valued Chinese for excellence in its own class. ${ }^{48}$

While the above theories hinted about the transition from one class to another, they did not systematically explain how and why the inflectional languages achieve perfection and then decay. The historian Olga Amsterdamska argues that by Schleicher's time in the 1840s, linguists tried to come up with scientific laws similar to the natural sciences even more than the Early Romantics. ${ }^{49}$ Schleicher took up the morphology issue as well and divided human time into prehistory and history. He argued, similar to Humboldt, that language progresses from an isolating to an inflectional stage in prehistory, but decays in history and loses the former unity of meaning and form. Schleicher's rationale for the division between prehistory and history was that language was not yet perfected in the

\footnotetext{
47 Müller, “Letter,” 22-23.

48 Robins, 196.

49 Amsterdamska, 44.
} 
former, and so humans were not free rational agents owing to a direct relation between lower linguistic and cognitive development. ${ }^{50}$ In history, humans are free agents and fall under the laws of phonetic decay, which push languages towards easier pronunciation, less irregularities, and simplification —at the cost of losing the perfect unity of meaning and form. These laws do not operate in prehistory, when he supposed a Hegelian counterforce named Sprachgefühl (language-spirit) leading languages towards perfection.

There might be numerous gaps and flaws in Schleicher's grand narrative such as the question of prehistory and history for non-Indo-European languages and the rather ad hoc admission of a guardian-angel of language called the Sprachgefühl. Still, including him in the survey of early-nineteenth-century linguists can help one see how the idea of morphological classification emerged and changed in this period. There was an oftrecurring image of all languages beginning like Chinese in their most ancient phases, and some languages progressing onto the agglutinating and the most advanced inflectional stages over time. Many linguists subtly distinguished this historical evolution of linguistic morphology from purely genealogical classification based on the presence of cognate words and sound shifts (Grimm's law). For instance, they were aware that both the Semitic family (including Arabic and Hebrew) and the Indo-European family were inflectional, but not so closely genealogically related to each other. ${ }^{51}$ Yet, regarding the Turanian case, as most of these languages were agglutinating, morphology became one

\footnotetext{
50 Amsterdamska, 47.

51 Müller, “Letter," 227.
} 
factor that some linguists like Castrén used to argue that these languages could be of common descent. I will now turn to the linguistics of the Turanian languages in this era.

\section{Early Classifications of the Turanian or Uralo-Altaic Languages}

The attention to studying languages historically and comparatively, and to grouping their genealogies and morphologies led some early-nineteenth-century linguists to go beyond the Indo-European family. As Leibniz had earlier hypothesized, Hungarian and Finnish were closely related and were speculated to share a common ancestral language with several Asiatic languages. The already established relationship between Indo-Iranian and European languages supported the idea of the Hungarians and Finns having their own Asian relatives. The word "Turanian" was often loosely used by European linguists to express a large family of these non-Indo-European languages that were also non-Semitic. This term finds one of its earliest usages in the ancient Persian and Zoroastrian hymns of the Avesta, which called the Central Asian land north of Iran beyond the Oxus as "Turan." 52 Turan was then occupied by nomads of possible Turkic descent, who were often hostile to the Iranians. The famous eleventh-century poet Firdusi's Shahnameh that describes Iran's mythical history refers to Tur and Irij as two brothers who founded Turan and Iran. ${ }^{53}$ Tur's murder of Irij began the hostility among their descendants.

By the late eighteenth century, some European philologists took up the idea of Turanians as a non-Iranic nomadic people inhabiting Central Asia. The English Orientalist John Richardson edited an early trilingual dictionary of Persian with Arabic

\footnotetext{
52 Naval Intelligence Division of Great Britain, A Manual on the Turanians, 12.

${ }^{53}$ Naval Intelligence Division, 13.
} 
and English in 1778-80 in collaboration with William Jones. He referred to the word "Turanian" as a synonym of the Tataric peoples of Central Asia, and is likely to have borrowed the idea from Persian texts. ${ }^{54}$ Over the next half century, several linguists like Gyarmathi, Klaproth, Rask, and Castrén wrote about the non-Indo-European languages of Eurasia with some awareness of the term "Turanian," even if they did not accept it as the right one. As one can see from chapter 2 onwards, Max Müller would be among those who closely tied this term to the non-Aryan and non-Semitic languages of Europe and Asia. Before Müller began publishing his few texts on the Turanian languages, he appears to have heard about this term from the Prussian ambassador to England Christian Karl von Bunsen, who, himself a scholar, supported Müller financially. ${ }^{55}$ The following pages will focus on the major linguists who studied the Turanian languages preceding Müller.

Earlier linguists often did not perceive a large family of languages encompassing the Finno-Ugric, Samoïedic, Turkic, Mongolic, and Tungusic (Manchu and its relatives) branches. In fact, some pioneers in this field explicitly rejected such an idea, claiming that only some subsets of these languages were related. The Hungarian Sámuel Gyarmathi, who developed some of his theories at the German University of Göttingen, published a thorough text in Latin in 1799 relating Hungarian to Sami (of the Lapps) and Finnish. This was not the first attempt, as an earlier Hungarian János Sajnovics had already suggested the relation between Sami and Magyar in 1770. Just when comparative studies of Indo-European languages were getting underway after William Jones's

\footnotetext{
${ }^{54}$ Naval Intelligence Division, 14.

${ }^{55}$ Naval Intelligence Division, 14.
} 
discovery, Gyarmathi's conclusion rested on comparisons of inflectional and derivational suffixes, postpositions, pronouns, adverbs, and syntaxes among these non-Indo-European languages. ${ }^{56} \mathrm{At}$ the same time, he denied a common ancestry of these languages with Turkish and other Tataric ones, citing wide differences in pronominal elements between the Finnic and Turkic families. This view of a narrow Finno-Ugric genealogy as opposed to a Uralo-Altaic one would continue on as a major alternative to the Turanian theory.

During the late eighteenth century, when Gyarmathi was doing his comparative studies of the Finno-Ugric family in Göttingen, a number of other Göttingen linguists also resisted the idea of a broader Turkic and Turanian origin of the Magyars. ${ }^{57}$ These linguists, led by the German historian August Schlözer, saw the widely-claimed view in Hungary of their own Turkic ancestry as populist and unscientific. The Hungarians had long had a romantic-heroic tradition of associating their ancestry with nomadic conquerors from the East like the Huns. These differences led to much friction between Hungarian and German scholars beyond linguistics. The publication of Sajnovics' book relating Hungarian to Sami in 1770 was perceived by many Hungarians as a dishonor to their nation, as they saw the Lapps as poor and backward. ${ }^{58}$ Popular sympathy after 1800 among the Hungarians thus favored a Turanian alternative to the Finno-Ugric theory supported by Schlözer and Gyarmathi. As with the search for Indo-European genealogies

\footnotetext{
56 Müller, "Letter," 11.

${ }^{57}$ Miklós Zsirai, "Sámuel Gyarmathi, Hungarian Pioneer of Comparative Linguistics," in Portraits of Linguists: A Biographical Source Book for the History of Western Linguistics, 1746-1963, ed. Thomas A. Sebeok (Bloomington: Indiana University Press, 1967), 60.

58 Zsirai, 59.
} 
inspired by German Romanticism, the search for Turkic relatives of the Hungarian language found a base in Hungarian nationalism. This inspired research about the East.

Meanwhile, some other Europeans studying these languages then were also reluctant to see a large Turanian family or connected Finnic and Turkic to other stillunclassified languages like Basque and Caucasian. The French Sinologist Jean-Pierre Abel Rémusat published on Tataric grammar in 1820, and argued that Turkish, Mongol, and Manchu might not be genealogically related. For Rémusat, these languages had far greater grammatical differences than those among Indo-European ones like Italian, German, and Russian. ${ }^{59}$ Even in the 1850s, linguists like the German Indologist Otto von Böhtlingk, who had himself published a book on the Yakut and other Turkic languages of Siberia, warned against Western Europeans drawing conclusions about the genealogies of languages they had never learned. ${ }^{60}$ Turanian languages, moreover, often had sparse literatures, grammars, and dictionaries. Yet there were attempts at alternative genealogies like that of the German traveller to the Caucasus Julius Klaproth, whose monumental work Asia Polyglotta (1823) linked Caucasian languages with Samoïedic and Finnic. Another German Christian von Arndt related the Celtic, Basque, and Finnic languages.

The above linguists Gyarmathi, Rémusat, Klaproth, and Arndt might have denied the existence of a Turanian family, but there were other scholars who helped provide a foundation for the later Turanian theory. The Danish linguist Rasmus Rask specialized in the comparative grammar of Germanic languages, but also made key observations on

\footnotetext{
59 Müller, “Letter,” 12.

60 Müller, “Letter," 19-20.
} 
non-Indo-European languages ${ }^{61}$ His researches in the first decade of the 1800 s were on Old Norse and Icelandic, and their relations to other Indo-European languages like Greek and Latin. He also traveled to Iceland, Russia, Persia, India, and Ceylon in the 1810s. Parallel to the Indo-European family, he saw what he termed a "Scythian" family of languages including Finno-Ugric, Turkic, Mongolic, Manchu, Greenlandic, and even North American. These languages, except the American ones, were later incorporated into the Turanian theory. For Rask, the Scythian languages originally extended from the polar north southward, but the southern parts were later surrendered to the Celts and Germanics. ${ }^{62}$ This view of an expansive family of polar languages was quite speculative as Europeans had limited data on many of these languages. It also went together with a belief in an antediluvian bridge connecting Europe and America via Greenland. ${ }^{63}$

Rask's Scythian category would be very similar to the Altaic family that the pioneering Finnish linguist Matthias Castrén proposed in 1850. Castrén classified only European and Asian languages, and began his studies in the 1830s with a deep curiosity about the ancestries of Uralic and Siberian relatives of Finnish. As a student at Alexander University in Helsinki, he was frustrated by the lack of literary and linguistic records of East-Finnic and Samoïedic speeches. ${ }^{64}$ His fervent yearning to study the languages and cultures of these peoples in situ led him to travel to Lapland (1838), to the Urals (1841-

\footnotetext{
61 Thomas Sebeok, Portraits of Linguists, 197.

62 Müller, “Letter,” 13.

63 Müller, “Letter,” 12.

64 Georg Hartwig, The Polar World: A Popular Description of Man and Nature in the Arctic and Antarctic Regions of the Globe (London: Longmans and Green, 1869), 112.
} 
43), and to the Ob, Yenisei, and Lake Baikal regions of Siberia (1845-47). These travels included perilous journeys by sledge in Siberian winters, where he faced numerous lifethreatening situations on water, ice, and snowstorms in the tundra. He hoped to stay temporarily in the small settlements of Samoïeds and Ostiaks and learn their dialects through native helpers. ${ }^{65}$ The natives were mostly kind and willing to help him, but he had difficulties acquiring languages through them. Unused to the mental exertions of thinking about grammar, they wished to stop teaching him and get back to their nomadic lifestyle. ${ }^{66}$ Castrén also suffered from frequent diseases while living in the tundra.

Castrén's travels and subsequent publications before his rather early death in 1855 at the age of forty-two lent support to a different theory of Finnish genealogy than the Finno-Ugric view of Schlözer and Gyarmathi. Castrén published his travel memoirs, grammars of the Cheremiss and Zyrians of the Urals (1844), a grammar of the Ostiak language of Siberia (1849), and some books and lectures on a grand family of "Altaic" languages (1850). The first few books concerned the closest relatives of Finnish and Hungarian. However, his works had a larger objective than to merely establish relations within the Finnic family. The Altaic family was essentially what later came to be referred to as the Turanian or Uralo-Altaic family, including Finno-Ugric, Samoïedic, Turkic (or Tataric), Mongolic, and Tungusic. Castrén wished to assert a broad genealogical tie among all these languages, with their possible collective origin in the Altaic mountains of

\footnotetext{
65 Hartwig, 175.

66 Hartwig, 177-178. Georg Hartwig (1840-1927) was a German Lutheran theologian who included a biography of Castrén in his 1867 text on the polar regions. This was about a decade after Castrén's death.
} 
Central Asia ${ }^{67}$ His grouping of various languages into these categories resembled that of Rask with the exception of North American languages, which Castrén left out as unsure. Finnish and Hungarian were just one branch of a much larger genealogical grouping.

This theory of a greater Altaic family, while supported with linguistic arguments by Castrén, was not entirely a revolutionary idea. As mentioned above in the opposition to Schlözer and Gyarmathi's Finno-Ugric theory, there were already Hungarian nationalists constructing their ethnic relationships to heroic nomadic conquerors from the East. Yet Castrén's early push in the Turanian direction raises the question of how he managed to relate such diverse languages as those scattered across Asia and some parts of Europe. These languages were spoken by peoples with enormous cultural differences from the nomadic Samoïeds to the European Hungarians. Gyarmathi had dismissed similarities of grammar between Hungarian and Turkish as the result of chance borrowing. ${ }^{68}$ In contrast, Castrén did not see the similarities among the "Altaic" languages as so few that they might not have had a common ancestor. One common element he found in the Altaic family was the agglutinating method of affix formation. He recognized that morphology was per se insufficient to prove common ancestry, and so he also drew on other linguistic and ethnological similarities among the Altaic peoples. Many in future eras-including Müller-would make similar arguments in support of the Turanian family idea. In the next section, I examine Castrén's lectures to show his elaboration of this argument.

\footnotetext{
67 Müller, “Letter," 17-18.

68 Müller, "Letter," 11.
} 


\section{Castrén's Ethnologische Vorlesungen über die altaischen Völker}

Of Castrén's various books on linguistics, there was one posthumously published set of his lectures on the Altaic family that he had delivered at Alexander University in 1851. These lectures came after his final trip to Siberia and contained his views on the linguistics, ethnology, and histories of the Altaic peoples. The original Finnish version was unfinished for publication, given Castrén's own ill health and bureaucratic duties as a professor at the time. Yet Finnish, Swedish, and German versions of these lectures were published after his death. The German translation was published in 1857 by Castrén's contemporary Franz Anton Schiefner, a Baltic German linguist who had also produced a twelve-volume set of Castrén's collected works in German. Schiefner himself was a reputed philologist of Finnish and Tibetan. His translation was entitled Ethnologische Vorlesungen über die altaischen Völker (Ethnological Lectures on the Altaic Peoples). These lectures were not merely on linguistics and aimed to show the broader cultural relations of the Altaic peoples too. Interpreting this German translation might not give the reader the spirit of the Finnish original, but it can be insightful as German was the medium through which European linguists like Müller engaged with Castrén's oeuvre. ${ }^{69}$

In his lectures, Castrén set his Altaic family theory in the context of contemporary theories of historical linguistics. He began by defining his objective of uniting the comparative study of languages and cultures in order to uncover hidden mysteries of the

\footnotetext{
69 Müller, “Letter,” 14.
} 
past of the Finns and their relatives. ${ }^{70}$ Though linguistics might share this objective with philological studies of classical texts, Castrén separated linguistics from literary studies that use language as a means to interpret old texts and understand the thinking of the ancients. Philologists might concentrate on a few literary languages, but linguists must consider any language in relation to many more languages and dialects that may or may not have a high literature. In this regard, he noted Schleicher's analogy of the philologist as a gardener focused on planting a few specific types of roses, while a linguist is like a zoological taxonomist detecting patterns in the overall evolution of species. ${ }^{71}$ Separating nineteenth-century historical linguistics from older speculations on the nature of languages, he claimed that linguists must work empirically with facts collected on many languages and discover relationships - a genealogical interest that tied Castrén to his era. In addition to comparing related languages, Castrén stressed the comparison of manners and customs of peoples, i.e. using ethnology as a sister science of linguistics. ${ }^{72}$ As many societies around the world lacked a high culture and literature, traditional methods of literary analyses might not be helpful to study, for instance, nomadic reindeer herders like the Samoïeds. Castrén's travels came out of his frustration with the limits of written texts in helping one understand less privileged people. Ethnological insights he brought into the relationship of Altaic peoples were nomadism and the practice of exogamy supposedly being common to Finnic, Turkic, Mongolic, and Tungusic

\footnotetext{
${ }^{70}$ Matthias Alexander Castrén, Ethnologische Vorlesungen über die altaischen Völker nebst samojedischen Märchen und tatarischen Heldensagen, trans. by Franz Anton Schiefner (St.Petersburg: Buchdruckerei der Kaiserlichen Akademie der Wissenschaften, 1857), 12.

${ }^{71}$ Castrén, 4.

72 Castrén, 7.
} 
peoples. ${ }^{73} \mathrm{He}$ argued that such similarities of customs among peoples could assist linguists in discovering the early histories of Finnic and other peoples. In contrast, the methods of physiology and craniology were less fruitful for Castrén in finding genealogies. He saw ethnolinguistic classifications as more in agreement with each other than craniological ones, whose results often clashed with ethnolinguistics. ${ }^{74}$ This made him hold on to the Altaic theory despite some craniologists' claims relating the Finns, Slavs, Persians, and Afghans based on skulls. To some extent, however, Castrén's method conflated linguistic and ethnic genealogies — an issue Müller would later dispute.

Alongside Castrén's emphasis on genealogy, another issue relating him to IndoEuropeanists like Bopp and Humboldt was his emphasis on grouping languages on the basis of their morphological categories. Castrén looked at the agglutinating nature of the Altaic languages as one reason for suspecting that they must have had common origins. ${ }^{75}$ These languages tend to have root words connected to affixes, which do not carry an independent material meaning. The roots and affixes are usually clearly distinguishable from one another, and the points of adhesion are apparent. Castrén recognized that some non-Altaic languages of Southeast Asia, southern India, and North America were also agglutinating, but did not include them in the Altaic family. ${ }^{76} \mathrm{He}$ reasoned that other linguistic and cultural similarities occasioned only Finnic, Turkic, Samoïedic, Mongolic, and Tungusic to be included as Altaic languages. These other linguistic similarities he

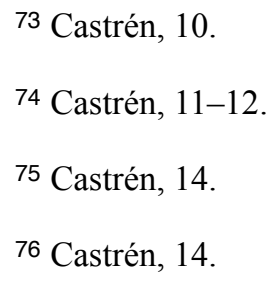


noted were the use of postpositions instead of prepositions, lack of prefixes, absence of consonantal clusters at the beginnings and ends of words, vowel harmony that makes the vowels of roots and affixes the same, and a large shared vocabulary within the family. ${ }^{77}$ Cultural parallels like nomadic heritage and exogamy also united the Altaic family.

It is important to note that Castrén did not merely assume that morphological similarity implied a common genealogy. He was careful to note several other factors to justify his choice. For Castrén, the agglutinating nature of the Altaic languages only made their common ancestry plausible, but did not prove it. Nevertheless, he viewed the presence of cognate words and other grammatical similarities among these languages as significant enough to establish that they descended from a common source. In this regard, he differed from Gyarmathi—who dismissed such likenesses as accidental borrowings. Castrén's exclusion of the agglutinating South Asian languages from the Altaic family also suggests his distinction between morphological and genealogical classifications. Further complicating the picture, Castrén found much variation in the degree of agglutination even within the Altaic family. ${ }^{78}$ Languages in the Tungusic and Mongolic branches seemed to him to display some properties of isolating languages like Chinese like the retention of material meaning of affixes. In contrast, the western Finnic languages took up a few attributes of the inflectional Indo-European languages. These variations in morphology were not a problem for Castrén in grouping these languages genealogically.

\footnotetext{
${ }^{77}$ Castrén, 18.

78 Castrén, 17-18.
} 
Castrén's view of the place of agglutinating languages in the evolutionary history of languages resembled those of his contemporaries. He too accepted the superiority of inflectional languages, though as a Finnish nationalist, he was sympathetic towards the agglutinating languages and expected their future progress towards inflection. ${ }^{79} \mathrm{He}$ referred to the contrasts between the Schlegels' and Bopp's views on inflection, and favored Bopp's idea that inflectional languages had developed from earlier agglutinating and isolating stages. ${ }^{80}$ In the earliest stage, all languages were like Chinese with each word being monosyllabic and carrying a material meaning. Words did not represent relations like parts of speech, cases, moods, and tenses, which were instead conveyed through word positions in a sentence. For Castrén, Chinese continuously preserved this earliest stage because of stability being an essential national characteristic of the Chinese that got reflected in language. ${ }^{81}$ Over time, as many tribes migrated and changed in their customs, there was a tendency to combine such isolated words together for ease of usage. This led to agglutinating languages that combined roots and affixes, with the two parts partly losing their material meaning and denoting relations. The perfect union of the root and affix formed the last stage of language growth, leading to inflectional languages.

Castrén put Finnish in the same genealogical category as other Altaic languages, even when he thought that it became a little inflectional owing to the Finns' proximity to Indo-European languages. He understood that there were enormous differences among

\footnotetext{
${ }^{79}$ Castrén, $17-18$.

${ }^{80}$ Castrén, 16.

81 Castrén, 16.
} 
the cultures of various members of this family, but still imagined a possible common genesis. His name "Altaic" family for these languages came from his view that the region surrounding the Altai mountains could have been their Urheimat (original homeland). ${ }^{82}$ Intending to contrast it against the supposed Caucasian origin of Indo-European languages, he reasoned that there were still Turkic and Mongolic peoples living in the Altaic region. Moreover, Castrén was aware of other common names for this family like "Turanian," "Tatar," and "Scythian." The Turanian reference seemed to him too narrowly concentrated on Central Asian Turks, without much connection to the Finns. ${ }^{83}$ This term, however, would be popularized by later linguists like Müller and Ármin Vámbéry, and would be used by many Turanist nationalists in Hungary and the Ottoman Empire by the late nineteenth century. The other terms Tatar and Scythian had negative connotations in European history. Castrén avoided these labels for the Finns given his nationalism. ${ }^{84}$ Besides linguistic arguments for an Altaic family, Castrén claimed ethnological similarities of customs and manners among the five Altaic branches. He mostly saw their nomadic customs as more primitive than those of the Europeanized Finns, but sometimes romanticized the heroic bravery and simplicity of the Altaic peoples. The two easternmost branches were the Tungusic and Mongolic. For Castrén, the former included the Manchu, Lamuts, and Tshapogires of Russia and China, and the latter the Eastern Mongols, Buriats, and Kalmyks. He took a mostly historical approach to understand the general

\footnotetext{
82 Castrén, 21.

${ }^{83}$ Castrén, 20-21.

${ }^{84}$ Castrén, 20.
} 
character of each branch, and frequently quoted ancient Chinese chronicles, accounts by the Jesuits, recent travelers to the Far East like Klaproth, and even supernatural legends circulated about heroic figures like Genghis Khan. Castrén claimed that the Tungusic branches were nomadic reindeer herders, hunters, and fishers, and were daring and adventurous, though often unclean, barbaric, and wild. ${ }^{85} \mathrm{He}$ noted how a small population of Manchus successfully got to rule over China, and thereby became more cultured. On the other hand, the Mongols were portrayed as once-powerful and fierce people who became pacifistic through Buddhism and Chinese control. ${ }^{86}$ For Castrén, an ethnographic feature uniting these peoples was their nomadic lifestyle and closer contact with nature. The linguistic and cultural similarities of these Altaic peoples paralleled each other. Castrén classified the remaining Altaic peoples in Central and Western Asia under the Turkic and Samoïedic branches. He presented the Turks as a once united, big, and fierce warrior group that threatened the settled cultures of Asia and Europe. ${ }^{87}$ Relying on Chinese, Persian, and Arab chronicles of the Turks, Castrén showed how the ancient Hsiung-nu nomads exemplified this fierce side of humanity in their attacks on China. However, he recognized that not all Turkic groups through history were homogenous. He mentioned the Turkic Tukiu kingdom of the seventh and early-eighth centuries receiving envoys from Byzantium and impressing Europeans with its wealth and artistic works. ${ }^{88}$ The Uighur kingdom succeeding the Tukiu was noted for its written script, and promotion

\footnotetext{
${ }^{85}$ Castrén, 25-31.

86 Castrén, 34-35.

${ }^{87}$ Castrén, 53.

88 Castrén, 63.
} 
of literature and high culture. Over time, Castrén saw the Turks dispersing themselves widely across Eurasia with many stems like the Turkmen, Bashkirs, Kirghiz, and Seljuks in Asia, and others like the Avars, Bulgars, Pechenegs, and Cumans in Europe. In contrast to the Turks, the Samoïeds were poor, peaceful groups of fishers and hunters occupying the Siberian tundra near the $\mathrm{Ob}$ and sometimes getting assimilated into the neighboring Russians. Castrén generally saw these cultural differences among different branches of the Altaic family as later occurrences that did not invalidate their shared nomadic origins.

The Altaic group that mostly drew Castrén's attention in his lectures was his own Finnic group, which took up nearly a half of the text and still remained unfinished. His interest, as a Finnish nationalist, in better understanding Finnish genealogy is apparent. Castrén saw the Finns as the most culturally Europeanized of all Altaic people, but refused to include the Finns with other Europeans genealogically and linguistically ${ }^{89}$ Attributing the Finns' cultural advancement to circumstances, he argued for the Finns sharing a common ancestral home along with the other Altaic people. Castrén mentioned four related branches of the Finns named the Ugric, Permic, Bulgaric, and the Western Finnic groups. The Ugric branch included the Hungarians and their closest relativesespecially the Ostiaks about whom Castrén had recorded much in situ. The Permics were small tribes in the territory of European Russia, and the Bulgarics encompassed some Volga peoples related to the pre-Slavic Bulgarian language. The last group consisted of the Finns proper, the Lapps, Karelians, and Estonians. Though some Finnic languages

89 Castrén, 89. 
were a little more inflectional than the Turkic ones, Castrén held that, in addition to morphology, similar words, customs, and religious histories related these branches. ${ }^{90}$

Castrén's lecture on the Finnic group was incomplete insofar as it did not cover the major Western Finnic languages like those of the Estonians, Suomi of Finland, and Lapps. The Hungarians too got less attention, as also the major Osmanli Turkish language of the Turkic branch. Castrén mentioned that he did not dwell much on some prominent groups as their histories were widely known. ${ }^{91}$ Other groups got missed out owing to his lack of time to consolidate his lectures into a publishable book. Nevertheless, he gave the most attention to less-known relatives of the Finno-Ugric family like the Ostiaks. As a Ugric group spread eastwards from the Urals to Siberia, the Ostiaks were also nomadic reindeer herders, fishers, or hunters similar to the Samoïeds. For Castrén, they were a people with a strong sense of communal responsibility and devotion to the tribes they were part of. ${ }^{92} \mathrm{He}$ vividly described their seasonal religious festivals involving images of tribal gods, shamans as interpreters of the gods, sacrifices of reindeer, and nightly weapon dances. ${ }^{93}$ Castrén wrote in an interested tone and appeared to have a sense that all Altaic peoples had similar customs to these in their earliest stages. A nomadic life, division into tribes, shamanism, exogamy, and grooms paying bride-price were some key similarities he imagined. Divergences from these original customs occurred later.

\footnotetext{
90 Castrén, 95-96.

91 Castrén, 131.

92 Castrén, 107.

93 Castrén, 108-118.
} 
Castrén's idea of relating these five branches of diverse peoples scattered across Europe and Asia into a single family paralleled the construction of the Indo-European family in the same period. His view that the Altaic languages were passing through the agglutinating stage of morphological evolution and his expectation that they would pick up features of the supposedly superior inflectional languages in future emerged in the context of theories developed by Indo-Europeanist linguists. Like the linguists before him, Castrén distinguished between morphology and genealogy, but it appears that the shared agglutinating natures of the Altaic languages gave Castrén a hunch that these languages could be of common descent. He supported this idea of an Altaic family by noting their other linguistic similarities. He also saw ethnological observations of each people's customs and manners as a helping-science of linguistics. His imagination of all Altaic peoples sharing similar ways of life like nomadism and shamanism in the distant past made him stand his ground on their common origin. Castrén did not make a distinction between the origin of the language family and the actual people. This issue of what features held the Altaic or Turanian family together would continue in later eras.

\section{Some Conclusions}

This chapter has focused on the early-nineteenth-century context of the emergence of the Turanian theory, and the linguistic and ethnographic reasons underlying it. The historiography of Turanism thus far emphasizes studies from the late nineteenth and early twentieth centuries. Historians like Joseph Kessler, Jacob Landau, and Hugh Poulton have mostly written on the interconnections between the idea of Turan and nationalisms in Hungary and the Ottoman Empire. This is understandable given that the Turanian issue 
gained far more popularity then than during $1800-50$, when it was mostly a disputed subject among linguists. Yet it can be insightful to see how an earlier era treated the same issue, and how these ideas got passed on to a linguist like Müller, whose popular lectures on the science of language in the 1860s included sections on the Turanian theory. As this chapter showed, historical linguists of the early nineteenth century did pay attention to classifying non-Indo-European languages like the Turanian ones, although they came to widely divergent conclusions. Many did not see the similarities among these languages necessarily implying their common origin. Even the name "Turanian" was not always accepted, not even by pioneers like Castrén. Yet the seeds of future struggles between the Finno-Ugrists (linking only Finnic and Hungarian groups) and Turanists (linking the Finnic and Ugric with the Turkic and other Asiatic groups) were already sown.

The fascination for reconstructing national genealogies through historical and comparative linguistics, and the emergence of grand narratives of the morphological history of languages from isolating to inflectional classes were two oft-recurring themes in the early nineteenth century. While most linguists kept these issues distinct from each other, both trends affected the Turanian theory. Castrén himself saw the common genesis of these languages plausible owing to their shared agglutination and other grammatical and ethnological similarities. Using these arguments, Castrén imagined a family that included very diverse peoples from the far Eastern reaches of Asia to the plains of the Carpathian basin in central Europe. Castrén's Finnish nationalism gave him a slightly different outlook towards the Altaic people from that of the German linguists, as he was more sympathetic to the Asiatic relatives of the Finns and hoped for their future progress. 
Yet he too followed the hierarchical idea of morphological evolution in which the inflectional languages were superior to the isolating and agglutinating classes. His study of the ethnological customs of the Altaic peoples also suggested their more primitive condition in relation to European cultures, though he occasionally valorized the heroism and simplicity of their nomadic lifestyles. The next chapter will detail how Müller picked up on classifying languages in the 1850s and how he related to Castrén's theories. 


\section{CHAPTER 2 \\ Family, Nomad, and State Languages: Max Müller and the Turanian Languages Theory in the $1850 \mathrm{~s}$}

Let us think for a moment of all the changes and chances of nomadic tribes, - - of the small sphere of ideas and words in which their language moves permanently and continuously, - of the little support which expressions of a higher range ... would receive in the Asiatic steppes, where men spend their life between hunting, fishing and eating, and women are kept only for breeding children and feeding cattle!

—Max Müller, "Letter on Turanian Languages," 1854, p.70.

To use a homely illustration, the uniforms of the Arian languages are actually made of one and the same piece of cloth and by the same hands, while the uniformity of the Turanian dialects lies not so much in the stuff, as in the cut and make of the dress.

-Müller, The Languages of the Seat of War in the East, 1855, p.90.

Beginning in the 1850s, the expatriate German scholar Max Müller became a participant in the European discourse on classifying non-Indo-European languages. Early that decade, Müller was newly appointed as a professor of modern European languages at Oxford's Taylorian Institute. Though languages and their history remained an important philosophical focus and methodological tool for Müller throughout his life, his Taylorian professorship in his early thirties was when he gave the most attention to the relationships among world languages. Of Müller's publications in this decade, his “Letter on Turanian Languages" and The Languages of the Seat of War in the East referred to the Turanian family. Unlike Castrén, Müller was not a specialist on the non-Indo-European languages, but rather a young up-and-coming philologist working on editing ancient Sanskrit texts and teaching linguistics and German literature. He became internationally famous and a widely sought-after lecturer from the 1860s after his linguistics lectures at London's 
prestigious Royal Institution. ${ }^{94}$ Müller continued disseminating the Turanian theory in his lectures, but his focus shifted to religion and philosophy from the 1870s. He eventually disavowed some aspects of his Turanian theory in response to others' criticisms.

Müller's interest in comprehending the relationships among world languages was grounded in the comparative and historical linguistics of the early nineteenth century. Before coming to England in 1846, Müller was already well-versed in the linguistic works of the Schlegels and Bopp during his studies at Leipzig. ${ }^{95}$ He had grown up influenced by German Romantic musicians and writers, and had received a classical education in Greek and Latin during his Gymnasium years. His fascination for Oriental languages, especially Sanskrit, from his university period was itself a product of his Romantic enthusiasm for reconstructing the language, thought, and lifestyle of the ancestral Indo-Europeans. This fervent yearning also motivated his editing work on the ancient Sanskrit text of the Rigveda, which he believed to be the oldest written book of humanity. ${ }^{96}$ For him, interpreting this text could provide profound insights into the minds of early civilized humans and their historical development. The approach of studying humanity by exploring their past and genealogies—so prevalent then in linguisticsfound its way into Müller's study of language, and of even mythology and religion.

Working with the theories of earlier linguists, Müller used morphological classes of languages from isolating to inflectional categories as a key tool to explain the progressive

\footnotetext{
${ }^{94}$ Lourens P. van den Bosch, Friedrich Max Müller: A Life Dedicated to the Humanities (Leiden: Brill, 2002), xxiii.

${ }^{95}$ Bosch, 23.

96 Bosch, 36 .
} 
evolution of languages over time. Like the other linguists, he carefully distinguished these classes from genealogical classification, recognizing that the latter would also require demonstration of systematic sound shifts. ${ }^{97}$ In a way, Müller went further than his predecessors in emphasizing the significance of morphological classes by closely relating them to social structures and civilizational levels of the language speakers. He associated the isolating, agglutinating, and inflectional categories with family, nomad (or tribal), and state languages respectively. In connecting language and culture, he claimed to follow the Romantic philosophies of Herder and Humboldt, who, in Müller's view, imagined language as "the outward expression of the spirit or individuality of a nation." $" 98$ Müller projected the trend of isolating languages evolving into inflectional ones as similar to societies becoming more and more complex over time — from scattered families and tribes to politically unified societies under a state. These civilizational metaphors implied a hierarchy of social states in which the family and nomad classes were primitive stages in his teleological evolution of human history towards advanced modern states.

Associating the agglutinating languages with nomadic societies, Müller theorized that the agglutinating languages of Europe and Asia could form a grand Turanian family. How and why did the young Müller in the 1850s relate the concepts of agglutination and nomadism to hypothesize a major genealogical grouping? He resembled Castrén in separating morphology and genealogy, and in nevertheless providing several reasons to show that the two overlap in the Turanian case. Yet, in grouping languages into categories

${ }^{97}$ Friedrich Max Müller, The Languages of the Seat of War in the East (London: Williams and Norgate, 1855), 5.

98 Müller, "Letter," 22. 
like family, nomad, and state, Müller went further than Castrén in questioning whether the same universal linguistic methods could be used to understand "nomadic" Turanian languages as opposed to "state" Indo-European languages. Assuming the more primitive civilizational level of the nomads, he argued that their languages changed in a far more chaotic way than the Indo-European ones. Müller was also different from Castrén in separating language and race, implying that linguistic similarity need not mean racial similarity (though Müller himself would often overlap the two). Further, he differed in the languages he called Turanian. Besides the "Altaic" group, Müller saw agglutinating Southern Asian languages like Taïc, Malaïc, Tamulic, and the Himalayan Bhotiya dialects as Turanian. These were mostly non-Indo-European, non-Semitic, and non-Chinese languages in Asia and Europe. Müller would himself later reject the genealogical unity of this large grouping, and return to Castrén's Altaic family. Though flawed and based on presuppositions about primitive peoples, his Turanian theory illuminates how he subtly questioned the overlapping of language and race, and brought in a relativistic critique of the universality of linguistic principles. I first consider how Müller initially came to this issue from his ideological background and practical issues during the Crimean War.

\section{Max Müller's Early Life and Influences (1823-55)}

Max Müller's fascination for the Orient and its past grew out of his upbringing in the tiny German duchy of Anhalt-Dessau, with its central ducal palace, the rivers Mulde and Elbe, and encircling forests. A principality ruled by a duke named Leopold III (also called Father Franz) in the eighteenth century, Dessau managed to retain its independence during the upheavals between 1789 and 1815. The dukes were central to providing 
education, employment, financial support, and high culture for their subjects in the duchy. ${ }^{99}$ Müller's father Wilhelm Müller began his career as the duchy's librarian and school teacher, and became famous as a poet who wrote many Griechenlieder, in sympathy with the Greek independence struggle against the Ottomans. His unfortunate death when Max Müller was just four years old prevented the son from getting to know his father better. Yet he would later go on to publish more of his father's poetry. ${ }^{100}$ On his mother's side, his great-grandfather Johann Basedow was a famous educationist at Dessau, member of the duke's ministry, and a friend of Goethe. Despite the illustrious lineage, Max Müller and his sister grew up fairly poor after their father's death, and they and their mother depended on the duke's financial support. His hardships pushed Müller to responsibly take the place of his father early on and care for his family.

Growing up in poverty did not, however, exclude Müller from having access to the large network of intellectuals and artists who were his father's friends. Müller's family had long been close to the dukes of Dessau, and so the duke helped the family with its needs. The dukes promoted a vibrant culture in Dessau with a theater that hosted regular plays and operas, concerts, and discussions. Even as a young boy in elementary school, Müller got opportunities to learn to play the piano and organ from experts, and perform at the palace and church. ${ }^{101}$ In 1836, when Müller was twelve, his mother sent him to Leipzig to stay in the care of his father's friend Carl Gustav Carus and study at the

\footnotetext{
99 Nirad C. Chaudhuri, Scholar Extraordinary: The Life of Professor the Rt Hon. Friedrich Max Müller (New York: Oxford University Press, 1974), 18.

100 Chaudhuri, 37.

101 Chaudhuri, 25.
} 
famous Nikolaischule. This was to put Müller under a masculine authority to control his behavior after his grandfather's death. ${ }^{102}$ Müller mastered classical Greek and Latin at school, and got to know personally several Romantic musicians in Leipzig — thanks to his father's network. Felix Mendelssohn, Robert Schumann, and the Hungarian Franz Liszt were some composers he admired, and he saw Liszt perform in Magyar costume at Leipzig. Though Müller did not focus on music later at the University of Leipzig, it gave him a Romantic approach towards life and would win him popularity at Oxford.

It would be from his university years (1841-43) at Leipzig that Müller began to focus on languages, Oriental studies, and philosophy. As German universities usually gave students the freedom to enroll in diverse lectures, Müller explored numerous fields beyond Greek and Latin. His courses included the grammars and literatures of Sanskrit, Hebrew, Arabic, German, and Persian, and aesthetics, philosophy, and anthropology. $\mathrm{He}$ was able to study Sanskrit because the university had just created a professorship in this field under the Orientalist Hermann Brockhaus. Müller wished to not restrict himself to classical Western philology and instead chose Sanskrit, hoping to explore Eastern texts that were little-known in Europe. ${ }^{103}$ After graduating in 1843, he continued working on a German translation of the Hitopadesa, a collection of old Sanskrit fables. The next year he went to Berlin to access Sanskrit manuscripts bought by the Prussian state. ${ }^{104}$ Here, Müller enrolled in the courses of eminent Orientalists like Friedrich Rückert, Bopp, and

\footnotetext{
102 Chaudhuri, 27.

103 Chaudhuri, 80-81.

104 Chaudhuri, 39.
} 
Friedrich Schelling. Müller's interest was not purely in linguistics, but also in literature and philosophy. He was already questioning the then-dominant Hegelian paradigm's $a$ priori nature and its disconnect from historical facts, stressing instead an empirical approach towards studying the past. Müller also wrote a thesis on Spinoza's pantheism.

Despite being a young scholar struggling to live off his meagre scholarship, Müller was persistent in his desire to continue studying and editing ancient Sanskrit manuscripts. He turned down employment offers from the Austrian diplomatic service, from nobles who wanted him to tutor their children, and even from libraries. ${ }^{105} \mathrm{He}$ took the risk of an uncertain future and went to Paris in 1845 with his family friend to try his luck finding financial support for his research. This was where he met the Sanskritist Eugene Burnouf who encouraged him to work on editing and collating the Rigveda with medieval commentaries. Upon learning that some manuscripts of the Rigveda could be accessed only in London's East India Company library, Müller left for England temporarily in mid-1846. However, it was here that he unexpectedly came across someone who would offer him monetary support and stabilize his career, enabling him to stay in England for the rest of his life. This would also be the man who would get Müller to work on the classification of languages, including the Turanian family. This was the Prussian diplomat in London Christian Karl von Bunsen, who helped Müller continue with his editing work.

Müller's future in England came to be transformed by Bunsen's assistance, though the latter would stay there only until 1854 . Bunsen himself had been a prolific researcher and student who had studied numerous languages ranging from Norse to Arabic and

\footnotetext{
105 Chaudhuri, 39, 45, 60.
} 
Persian. Having been a secretary to the historian Barthold Niebuhr and an avid fan of the Egyptologist Jean-François Champollion, he was interested in the development of religions among various races of people. He was particularly curious about the Egyptian hieroglyphics, which he attributed to the earliest civilization. However, his involvement in politics in Rome and, later, in London as a friend of the Prussian King Friedrich Wilhelm IV prevented him from devoting much time to scholarship. ${ }^{106}$ Upon meeting Müller in London in 1846, Bunsen saw great potential in the young scholar passionate about the ancient Orient like himself. His financial support to Müller helped the latter continue his editing without the distraction of other jobs until 1850. Bunsen was also socially savvy with the political elite of Europe and hosted lavish dinners in which he introduced Müller to statesmen like Robert Peel, François Guizot and the Archbishop of Canterbury. ${ }^{107}$ These experiences helped Müller expand his social network in England. Müller's initial involvement in linguistics and his decision to live in Oxford from mid-1848 also came about through Bunsen's assistance. Though Müller had come to England hoping to edit manuscripts of the Rigveda, he was unable to find a profitable publishing offer for it. Eventually, it was Bunsen who put Müller on a sure footing by convincing the East India Company to accept the publication of this ancient text and pay Müller per sheet. ${ }^{108}$ This income stabilized Müller's path and enabled him to publish the first volume of the Rigveda by 1849. Even after he became a professor at Oxford, Müller

\footnotetext{
106 Bosch, Friedrich Max Müller, 39.

107 Chaudhuri, Scholar Extraordinary, 58.

108 Chaudhuri, 60. The six volumes were published as Max Müller, Rigveda Samhita. The Sacred Hymns of the Brahmans together with the Commentary of Sayanacarya, 6 vols (Oxford, 1849-74).
} 
would continue publishing his six volumes of this sacred text until the early 1870s. As Müller worked on this text in the late-1840s, Bunsen persuaded him to present a linguistics paper in Oxford at a meeting of the British Association for the Advancement of Science (BAAS) on the relationship between the Indo-European and other native tongues of India. Initially reluctant, Müller accepted the proposal, but dwelt mostly on the Indo-European family he was familiar with in his paper. ${ }^{109}$ Bunsen's question for Müller in this conference would, however, motivate the latter to think about other language families than the Indo-European one and propose the Turanian theory in the 1850s.

As Müller advanced in his career with Bunsen's help, he did not limit himself to just mechanical editing of ancient texts. He also had a passion for making generalizations based on the evidence at hand, which led him to the science of languages in the $1850 \mathrm{~s}$. Having studied Sanskrit in the German tradition at Leipzig, Müller was infused with the German enthusiasm for the Indo-European language family following the Schlegels, Goethe, Humboldt, and Friedrich Rückert. Müller explained his work on the oldest texts of this family as necessary for understanding humans in their earliest stage of civilization and their historical growth. He claimed, "The object ... of philology, in its highest sense, is but one, to learn what man is, by learning what man has been. With this principle as the pole-star, we shall never lose ourselves." 110 This principle of drawing general conclusions about humanity based on their historical experience as revealed in the language of ancient texts guided Müller's studies. His quest for generalities continued after his BAAS lecture

\footnotetext{
109 Chaudhuri, 62.

110 Friedrich Max Müller, A History of Ancient Sanskrit Literature, so far as it illustrates the Primitive Religion of the Brahmans (London: Williams and Norgate, 1859), 8.
} 
and his move to Oxford in May 1848. His success in publishing a volume of the Rigveda in 1849 and reviewing Bopp's linguistics textbook got him a deputy professorship in European languages at Oxford's Taylorian Institute from 1851.

As a professor of languages, Müller developed his theories on the genealogical affinities among world languages. His lectures included the history of romance languages, the origins and history of German civilization, language, and literature, and the Niebelungenlied. Müller tried to familiarize the Oxford community with German approaches to comparative and historical linguistics, and with the German classics. In his historical view of languages, he sympathized with the ethnologist James Prichard's view of the monogenesis of all human races and languages. ${ }^{111}$ This reflected Müller's PietisticLutheran upbringing, and the Biblical idea of the common origin of all humanity. Owing to Müller's experience with linguistics, Bunsen asked him in 1853 to contribute to his publication Christianity and Mankind by writing about the non-Indo-European languages of the world. The purpose was to study Christianity's place in relation to world cultures and to reach a unified philosophy of history. ${ }^{112}$ This was when Müller wrote his "Letter on Turanian languages," discussing the role of the Finno-Ugric, Turkic, Mongolic, and other Asian languages in world history within his monogenetic framework.

While Müller's background in the German and Lutheran tradition formed one avenue in which he came to the Turanian theory, there was also a practical side to his linguistic studies. As his biographers Lourens van den Bosch and Nirad Chaudhuri have

\footnotetext{
111 Bosch, Friedrich Max Müller, 52.

112 Bosch, 52.
} 
noted, Müller was living in the English world that had a much different attitude towards Sanskrit and modern Asian languages from the German world. ${ }^{113}$ Although the British had extensive colonies in the Orient and had had famous Orientalists like William Jones, there was little positive romanticization of their colonies. An overall neglect of the Oriental languages prevailed. Müller found this derogatory attitude towards the colonized harmful to relations between the latter and the Europeans, and damaging to British imperial interests. From the 1850s, Müller often campaigned through the press and his lectures to prepare British officers in colonial languages before sending them abroad. ${ }^{114}$ Seeing Müller's passion and knowledge of foreign languages, the British Secretary to the Treasury Charles Trevelyan asked Müller during the Crimean War in 1854 to write a linguistic survey informing British officers of the languages crucial for success in Eastern Europe. This practical issue led Müller to produce the work entitled Languages of the Seat of War that included the Turanian languages in the Ottoman and Russian empires.

Müller's engagement with the Turanian theory was, therefore, the combined result of his Romantic and historical worldview, his familiarity with the genealogical and comparative emphasis of the linguistics of his time, his presupposition of linguistic and racial monogenesis, his mentor Bunsen's encouragement, and his recognition of the practical importance of foreign languages for imperial and military purposes. Unlike the linguists Gyarmathi, Klaproth, or Castrén, Müller was not a specialist on any of the socalled Turanian languages and was not fluent in them. He did not attempt to study these

\footnotetext{
113 Chaudhuri, 134; Bosch, 58.

114 Chaudhuri, 182.
} 
languages in situ as Castrén did before him. Yet Müller's passion for generalizing about languages and their broader role in shaping human nature encouraged him to make this intellectual excursion outside of the Indo-European family with which he was more at home. Interpreting his thoughts on the other languages of Europe and Asia can not only add a valuable nuance to his biography, but also trace the course of evolution of ideas about the Turanian languages in the nineteenth century. Müller situated his own view in light of the earlier theories, and his later books on linguistics containing the Turanian theory were popular across Europe. The next section elaborates on how Müller saw the Turanian family in relation to other languages by considering his two texts "Letter on Turanian Languages" (1854) and Languages of the Seat of War (1855).

\section{Defining the General Characteristics of the Turanian Language Family}

Both of Müller's texts in the mid-1850s dealt at length with the Turanian family in relation to other groups like the Indo-European — which Müller called as "Aryan"—and the Semitic Near Eastern languages. For Müller, the Turanian family included most languages of Europe and Asia that were non-Aryan, non-Semitic, and non-Chinese, and his objective was to demonstrate in what respects these languages stood together. In his 1854 contribution to Bunsen's text, Müller tried to show that all world languages could be traced back to a common source in a Christian sense as "children of the same father," and emphasized the Turanian family as a large group that also evolved from a common ancestor. ${ }^{115}$ He subdivided this text into two parts- the first noting the general features of the Turanian languages in terms of grammar (formal) and words (material features), and

\footnotetext{
115 Müller, “Letter,” 76-78, 226.
} 
the second delving into specific branches of this large family. In contrast, Müller's second book to British officers during the Crimean War had a rather practical than a theological end. As per Trevelyan's request, Müller divided this book into three parts on the Semitic, Aryan, and Turanian languages of Eastern Europe respectively, listing their geographical spread and some foreign and English books useful to officers learning these languages.

To claim the relationship among Turanian languages, Müller treated the morphological similarity of agglutination among these languages as a heuristic tool. Yet, like Castrén, Müller was aware that morphological similarity did not by itself imply common descent. For instance, Müller advised the officers that learning other languages could be easier if they were familiar with linguistic principles on how languages were related to each other. Here, he explained to them that mere resemblances among words or grammatical endings would not suffice to group languages together as a family, as such features could be borrowed from unrelated languages. ${ }^{116}$ Persian took up pronominal suffixes after nouns—-similar to the Semitic family—instead of genitives or possessive adjectives as in other Aryan languages. Instead, Müller stressed that reasonable and systematic sound shifts among languages should be possible before establishing relationship. The Latin " $\mathrm{f}$ " as in "filius" and "facere" systematically gets replaced by an "h" in Spanish as in "hijo" and "hacer" respectively. ${ }^{117}$ As such systematic shifts were far more numerously observable in the Aryan and Semitic families, Müller faced the burden of showing how his vastly diverse Turanian group still made sense as a family.

\footnotetext{
116 Müller, Seat of War, 7-8.

117 Müller, Seat of War, 5.
} 
Müller hoped to explain the genealogical unity of the vastly diverse Turanian languages by first grouping them under the label of "nomadic" languages, and arguing that they have special features distinct from the Aryan and Semitic families. Nomadic languages, for him, were subject to extensive changes over time owing to the scattered, primitive societies of nomads. ${ }^{118}$ So it became possible even for widely differing nomadic languages today to actually be branches of a once-existing common ancestor. Müller went further to say that the differences in linguistic change between "nomadic" Turanian and settled peoples' languages were such that methods in the German comparative tradition like Grimm's Law (systematic sound shifts between related languages) were not useful to study nomadic languages. As I will argue in the coming pages based on Müller's writings on the etymologies and morphologies of Turanian languages, he questioned whether one set of universal linguistic principles and methods was sufficient to understand different classes like the Turanian and Aryan languages. He claimed:

In order to perceive [the common origin of Turanian languages], and to command this wide view, we must put aside the microscope through which we examine the organism and the ramifications of so small and modern a cluster of dialects as the Arian and Semitic. Different subjects require different methods, and because the method of Bopp and Grimm has been found applicable to an analysis of Arian speech, it does not follow that the same would lead to satisfactory results in higher and more comprehensive branches of linguistic study. ${ }^{119}$

Müller emphasized the differences among language families despite his view that all world languages had a common origin and might eventually reach the inflectional stage.

\footnotetext{
118 Müller, Seat of War, 87.

119 Müller, “Letter,” 214.
} 
Müller developed this idea of differences between nomadic and other languages based on how several earlier European linguists had morphologically grouped languages. As seen in chapter 1, there were theories that all languages began in the isolating stage like Chinese, before some passed through the agglutinating stage and eventually acquired inflections. Early-nineteenth-century linguists did not see all languages successfully transitioning, with some like Chinese getting arrested in the isolating stage. Müller took the idea that all languages began in the isolating stage as suggestive of their common origin. ${ }^{120} \mathrm{He}$ further related each morphological stage to a civilizational level that best harbored such languages. This Romantic sense that language is an outward reflection of the spirit of a people—which Müller borrowed from Humboldt and Johann Gottfried Herder-informed his linguistic relativism that languages in different stages need to be studied differently. Müller saw isolating languages belonging to the "family" stage, agglutinating languages to the "nomadic or tribal" stage, and the "advanced" inflectional languages to the "political or state" stage. He imagined settlements in isolated families as the earliest state of human existence, and modern nation-states as the latest in history.

The morphologies of languages matched their respective social states in their structures and functions. Isolating languages like Chinese, for Müller, retained consciousness of the earliest stage when humans lived in isolated families and used familiar words without many inflections that everybody could easily understand. Changes in tone were sufficient to convey differences in meaning, and these languages were best

120 Müller, "Letter," 23-24. 
suited for isolated meditation and family situations. ${ }^{121}$ In the next agglutinating stage, affixes that lost their independent meaning were attached to roots, but the two parts remained distinct with clear points of contact. Groups like the Turanian family with agglutinating features were best fitted to the life of tribes of multiple families in tents. The meanings had to be clearer to many unfamiliar people, and so more inflections and distinct roots were helpful. ${ }^{122}$ This nomadic lifestyle of clans formed a more complex social level than the family, but discourse was still scanty. Finally, in the most advanced society with a central state, laws, institutions, and high culture, the inflectional stage developed. As these societies had much continuity of memory and trust, roots and affixes could afford to lose their original independent meanings and fuse together into an organic whole. This reflected society itself fused into an organic community instead of an atomistic socially-agglutinated life. ${ }^{123}$ The civilizational counterparts to languages implied a hierarchical evolution from primitive to complex stages.

Of these categories of family, nomad, and state languages, Müller focused on whether all nomad languages could potentially be descendants of one common ancestor. While he did not deny the nomadic languages of a capacity to ascend or descend the morphological ladder, he argued that their primitive nomadic and agglutinating features made them significantly different from their Aryan and Semitic counterparts. His image of the nomads of Central Asia was that of scattered clans of people migrating in search of

\footnotetext{
121 Müller, “Letter,” 25.

122 Müller, “Letter,” 25.

123 Müller, “Letter,” 26.
} 
good pastures and rivers for their horses, cattle, sheep, or goats, and temporarily settling in such areas. He added that their habits remained unchanged from antiquity to the present. ${ }^{124}$ Clans occupying a good pasture area would soon face competition from other clans and battles for territory, and subsequent displacement to other far-away pastures. As Müller saw language and society closely reflecting each other, he claimed:

During these continued struggles their languages lose as many words, perhaps, as men are killed on the field of battle. Some words (we might say) go over like deserters - others are made prisoners, and exchanged again during times of peace. Besides, there are parleys and challenges, and at last a dialect is produced which may very properly be called a language of the camp,- - but where it is difficult for the philologist to arrange the living and to number the slain, unless some salient points of grammar have been preserved throughout the mêlée.... A number of tribes may be at times suddenly gathered by the command of a Kinghis-Khan or Timur, like billows heaving and swelling at the call of a thunderstorm. One such wave rolling on from Karakorum to Liegnitz may sweep away all the sheepfolds and landmarks of centuries. ${ }^{125}$

Just as nomadic societies differed from settled ones in their customs, goals, and levels of violence, the former's languages experienced much dislocation and needed to be studied differently. Müller claimed that the name "Turanian" derives from a root meaning "to be swift" and "to roam about as nomads" as opposed to a settled "Aryan" tiller of the soil. ${ }^{126}$ In the absence of a unifying centralized state, standardized laws and institutions, and a written literature that preserved language in an older state, nomadic languages were more prone to rapid losses of old words and their replacement by new ones. Müller took this claim further to argue that even if nomadic languages had descended from a common

\footnotetext{
124 Müller, Seat of War, 114.

125 Müller, Seat of War, 115.

126 Müller, “Letter,” 21.
} 
parent, the original stamp of the parent language's words and grammar would have been erased in the divergent offspring - making it harder to observe Grimm's Law at work. ${ }^{127}$ Even numerals and pronouns, which tend to resist phonetic corruption in any language owing to frequent usage, could easily lose their earlier forms in nomadic dialects. Müller did not expect nomads to often use highly abstract concepts in their "scanty" everyday speech, making such scarcely-used words further divergent in the offspring. ${ }^{128}$ Therefore, linguists should not expect to find in the Turanian family such careful preservation as that of the parent Indo-European language's features by its successors like Sanskrit, Greek, Latin, and Old Slavonic. Even widely separated Turanian tribes could have had a common parental language owing to their shared nomadic heritage. This emboldened him to claim their common origin even if Grimm's Law could not be proved here.

Given Müller's argument that nomadic languages could be genealogically related even when they did not obviously exhibit systematic phonetic correspondences, he added that their shared agglutinating morphology and certain grammatical similarities would suffice to establish their relationship. He recognized that such an argument would not work for settling all language families, as morphology is not genealogy. Yet in the special case of nomadic languages, Müller believed this argument could have some validity. He found most nomadic Turanian languages to be agglutinating in their word formation with affixes glued to the roots of words while the two parts still remained distinctive. For instance, in the declensions of the Hungarian noun kés (meaning knife) such as kés-em

\footnotetext{
127 Müller, Seat of War, 86-87.

128 Müller, Seat of War, 88.
} 
(my knife), kés-e (his knife), and kés-ünk (our knife), the root kés and the pronominal suffixes -em, $-e$, and -ünk are glued together without obscuring the root's form. He saw much regularity in how Turanian languages preserved the integrity of their roots, while the inflectional Aryan languages fused the root and affix so much that the resulting forms were irregular with the roots much harder to detect. ${ }^{129}$ Müller gave the example of the French noun $\hat{A g e}$, where the original root ae (from Latin aetaticum) is unclear. ${ }^{130}$ Müller also related his claim of most Turanian languages clearly distinguishing their roots to their nomadic lifestyle, and posited it as a general feature of this family. Much like how he expected nomad languages to lose their older vocabulary in their tumultuous lifestyle filled with migrations, battles, and deaths, he saw irregular grammars with obscured roots difficult to be remembered and passed down in such languages. ${ }^{131}$ Irregularities in grammar require a continuity of tradition to be passed on to future generations, but the Turanian languages were the "languages of the day"-spoken by nomads living for the present without profound historical consciousness. In the absence of written literature and standardized speech, every generation of nomads took part in the recreation of their language and in its regularization to simplify articulation. For Müller, the frequency of irregular inflections in Aryan languages showed their individuality in a Romantic sense, while the preponderance of regular forms in Turanian languages made them monotonous. ${ }^{132}$ Though he mostly viewed Aryan languages reflecting a far superior

\footnotetext{
129 Müller, "Letter," 28-31.

130 Müller, "Letter," 27.

131 Müller, "Letter," 31.

132 Müller, "Letter," 31.
} 
culture than the Turanian ones, he conceded that agglutinating languages gave speakers the power to regenerate new words and shed old ones, as their speakers combined roots and affixes self-consciously — a power that Aryan languages with obscured roots lacked.

Apart from agglutination, Müller found other grammatical similarities among Turanian languages. Unlike Aryan and Semitic languages, Turanian nominal and verbal roots are not so clearly separated from one another. ${ }^{133}$ In Müller's historical framework for languages, this was an intermediary morphological stage between Chinese roots lacking formal distinctions between nouns and verbs, and Aryan and Semitic families with well-differentiated roots for marking parts of speech. As Turanian languages were in the middle phase, many of their roots like the Hungarian fagy could be used both as a noun (meaning frost) and a verb (meaning freeze). To differentiate between these parts of speech, Turanian languages use different pronominal affixes to mark the cases of the noun (predicative pronominals) and persons of the verb (subjective pronominals). In the case of fagy, adding pronominal suffixes to form fagy-om (my cold) and fagy-ok (I freeze) works to separate different grammatical functions. This is different from Aryan and Semitic roots more clearly distinguishing nouns and verbs by reduplicating initial or final syllables to form verbs, or by using distinctive terminations for verbs. ${ }^{134}$ The Aryan and Semitic languages have thus developed much further in formal elements in Müller's view.

There are common patterns in how most Turanian languages employ pronominal affixes to describe the persons of nouns and verbs. Müller borrowed this idea from

\footnotetext{
133 Müller, "Letter," 36.

134 Müller, “Letter,” 45.
} 
Castrén's research, and claimed that the Northern and Central Asian Altaic languages use only pronominal suffixes after both nouns and verbs. For example, the suffix - $o k$ in Hungarian is a pronominal suffix indicating the first person as a subject after verbs-as in the word hallok (I hear). Similarly, nominal bases also take only suffixes, which tend to be predicative pronominals like -em that form words like késem (my knife). In these Turanian languages, the persons of the nouns and verbs are placed at the end regardless of whether they are the predicates of nouns or subjects of verbs. ${ }^{135}$ This pattern contrasts with Aryan languages in that the latter have only one set of pronominal suffixes, used after verbs. Instead of affixing pronouns after nominal bases, the Aryan family often uses genitives or possessive adjectives before nouns (as in the French mon père) to indicate the person. The Semitic family is different from Aryan and Turanian groups in employing pronominal suffixes after nouns, but not after verbs - opting to put the predicates last in both cases. ${ }^{136}$ Such contrasts in morphological patterns additionally divide these families.

Putting these grammatical similarities pertaining to agglutination and pronominal affixes together, Müller argued that the resemblances among Turanian languages were too many to have resulted from mere chance. To these similarities, he added the pattern of vowel harmony and postpositions in Turanian languages. ${ }^{137}$ Vowel harmony is the assimilation of vowels of the affixes to resemble vowels of the roots in Turanian languages like Finnic and Turkic. For instance, in the Turkish verbs sev-mek (to love) and

\footnotetext{
135 Müller, “Letter,” 56.

136 Müller, “Letter,” 52.

137 Müller, “Letter,” 77-78.
} 
$b a k-m a k$ (to regard), the affix-vowels in -mek and -mak respectively harmonize with the root vowels in sev-and bak-. Also, given the tendency of Turanian languages to clearly put the roots at the front of a word, they use postpositions instead of prepositions. One example is the word késemnek (to my knife) in Hungarian, where the postposition -nek (meaning "to") relates the noun to other words in the sentence. Considering such similarities, Müller argued that all Turanian languages originated from a common ancestral home in Central Asia. For him, this was also a probable Urheimat for all world languages, where languages began evolving from isolating to inflectional stages. ${ }^{138} \mathrm{He}$ imagined Turanian-language speakers dispersing in the middle agglutinating phase.

Müller's overall argument for a Turanian family rested on the presupposition that the nomadic Turanian languages behaved differently from those of settled peoples. This led him to claim that the very genealogical unity of the Turanian family differed from Aryan and Semitic ones. As this chapter's introductory quote from Müller alluded to, he saw Aryan languages uniform in their stuff and make of their clothes, but Turanian languages uniform in just the make but not the stuff. ${ }^{139}$ Here, he implied that nomadic languages could have much divergent words, but were related by their grammatical similarities. He theorized that nomadic peoples dispersed from their Urheimat well before humans came to live under a state, and therefore their languages lacked the uniformity of those that split up later. ${ }^{140}$ One danger of Müller's Romantic-inspired assumptions about

\footnotetext{
138 Müller, “Letter,” 220.

139 Müller, Seat of War, 90.

140 Müller, “Letter,” 218.
} 
nomadic languages is that they emboldened him to put languages with few historical and geographical ties in the same Turanian family. Expecting phonetic correspondences to be obscured in such languages, he grouped together distant tongues like Malay and Finnish after superficially examining their grammatical forms. As a result, he projected mere morphological likeness into a family, which makes his classification tenuous. This weakness is apparent in his reflections on specific branches of the Turanian family.

\section{Delimiting the Linguistic Geography of the Turanian Family}

Under the label of "nomadic" Turanian languages, Müller included not just the Eurasian “Altaic” languages like Tungusic, Mongolic, Turkic, and Finno-Ugric, but also Southern Asian languages like Taïc, Malaïc, Tamulic, and the Himalayan Bhotiya groups (including Tibetan and Burmese). This was unlike any earlier linguist's classification, as even Castrén had suggested only the northern half of this list forming a family. Yet it was Müller's assumption that even seemingly-unrelated nomadic languages could be related that led him to this classification. Such a large grouping of languages poses numerous problems, especially as they were not all homogeneously nomadic to be included in the same evolutionary stage of languages. The South Asian Tamulic group, for instance, has not had a nomadic heritage resembling the Eurasian nomads. Second, Müller could not document the historical interactions that these northern and southern branches had with each other. Many subgroups also lacked written historical records chronicling their own histories, making it hard for a linguist to decide which words in these languages came earlier than others and which were the result of borrowing from neighbors. Somewhat self-admittedly, Müller's grouping was superficial based on the limited data he had. 
While Müller, unlike Castrén, did not base his classification on an in situ data collection process and personal study of these languages, he brought in a fresh approach that separated linguistic classification from a racial one. ${ }^{141}$ This was different from Castrén, who saw the speakers of Altaic languages constituting a different race from those speaking Indo-European languages. Even the Finns were European only culturally, but biologically related to the Altaic peoples. However, for Müller, his classification of the northern and southern Turanian divisions into one family was merely a linguistic one, and did not say anything about physical features like skin color, facial angle, hair, and skull shape of these peoples. The Malays and Finns could belong to the same language group without sharing the same physiological features. Müller reasoned that it is possible for a people belonging to one race to adopt the language of another-like the Teutonic Normans taking up French and the Uralic Bulgarians adopting a Slavic dialect. ${ }^{142}$ Müller did claim that all world languages and all races had a common origin — given his monogenesis idea - but he held that the racial and linguistic divergences need not have occurred at the same time. ${ }^{143}$ One cannot infer racial similarity from linguistic likeness.

Müller used his classification to project backwards a history of how the Turanian migrations must have unfolded from the common center of human origins in Central Asia. He portrayed it as a description of how Turanian language communities came to be, and not as a claim about their racial type. Given the scarcity of data on many Turanian

\footnotetext{
141 Müller, "Letter,” 89-93.

142 Müller, "Letter," 91.

143 Müller, "Letter," 214.
} 
languages, Müller relied on previous collectors like Gyarmathi, Klaproth, and Castrén for the northern branch, and articles published in the Journal of the Asiatic Society of Bengal by the British ethnologist of Tibet Brian H. Hodgson for the southern branch. ${ }^{144}$ Even among Turanians, Müller saw a progression—like Castrén—from few affixes in the Tungusic and Taïc subfamilies to numerous agglutinating affixes (almost inflectional) in the Finnic and Tamulic branches. He turned this into a world historical narrative where Chinese speakers split off early from the common center in the family stage. Then, as languages in the center progressed, Tungusic and Taïc speakers wandered off first, followed by the Mongolic and Malaiic. Third to emigrate were the Turkic and Himalayan, and the fourth were the Finnic and Tamulic. The last to disperse were the Aryan and Semitic speakers, who then conquered the Turanians by their superior powers. ${ }^{145}$ Müller assumed that all languages started as isolating and some advanced to become inflectional.

Müller did not add significantly new insights on the "northern" Turanian division beyond what Castrén had already established. Still, he provided detailed notes on the major Uralo-Altaic groups in his essay on the strategic languages around the Crimean region, with emphasis on Ottoman Turkish, Caucasian languages, and those of Eastern Europe. The Tungusic and Mongolic groups in the Far East were quite like the isolating morphology of Chinese with few grammatical affixes. They rarely had pronominal affixes after nouns and verbs, but attempted to combine different material roots into a single word. This made them part of the agglutinating class of languages alongside the

\footnotetext{
144 Müller, "Letter," 83.

145 Müller, “Letter,” 225.
} 
Turkic and Finnic groups. For Müller, Ottoman Turkish was however the agglutinating language par excellence with unobscured roots and regular addition of affixes to indicate declensions and conjugations. It had close relatives in the East that he grouped under the eastern Chagataic, northern Kipchak and Siberian, and western Turkic branches. ${ }^{146}$ The Finnic group resembled the Turkic in agglutination, but had more irregularitiesapproximating the inflectional Aryan category. Müller also suspected Caucasian languages like Georgian, Circassian, Lesghian, and Mitageghian to be Turanian. ${ }^{147}$

It was by adding an entire geographic division of South Asian and even Pacific South Sea Island dialects to the Turanian family that Müller departed from earlier linguists. In the absence of rich data on many of these languages, Müller speculated that, in parallel to nomads of the land, there could be nomads of the sea like those speaking Malaïc and Polynesian dialects who were Turanian. His southern Turanian division was however too broad and included many settled peoples in the Himalayan, Southeast Asian, and South Indian regions as well. This grouping is unconvincing because Müller was not only unable to produce close phonetic derivations, but even similar grammars throughout. The Taïc subfamily that included Siamese and Khamti had the least grammatical affixes in this division and used prefixes or prepositions to express gender, number, and cases. ${ }^{148}$ This was different from most northern Turanian dialects that often had postpositions and suffixes to perform the same functions. The Himalayan Bhotiya subfamily formed the

\footnotetext{
146 Müller, Seat of War, 100.

147 Müller, Seat of War, 125-135.

148 Müller, “Letter,” 132.
} 
second southern Turanian branch, and it had more frequent affixes than Taïc while also using prefixes often. ${ }^{149}$ Müller tried to show the affinity of Taïc and Bhotiya by tracing numerals back to common types, but did not fully deal with their vast heterogeneity.

The inclusion of this southern division brought together even the Malaïc branch, which earlier linguists like Humboldt had put under the Polynesian family. As Müller imagined the Turanian family to be a catch-all for nomadic languages, he assumed that nomads of the sea might share the same genealogical grouping. This made him diverge from Humboldt to include the Malaïc dialects under the Turanian label. ${ }^{150}$ Here, Müller found some morphological similarities with the Taïc dialects in the pattern of affixes and parts of speech. One pattern he identified in Turanian numerals was their derivative naming of numbers seven, eight, and nine as $6+1,10-2$, and $10-1$ respectively. ${ }^{151}$ In his examination of the last southern Turanian division of South-Indian Tamulic languages, Müller continued looking for grammatical forms they shared with other Turanian languages. The Tamulic dialects closely resembled the Finnic in their numerous affixes and declensions, making Müller see these two branches as the most advanced Turanian groups. Though the Finnic and Tamulic were far apart in vocabulary and recorded histories, he managed to bring out some affinities in numerals and pronouns, affixes expressing gender, number, and case, and syntactical structures tying them together. ${ }^{152}$

\footnotetext{
149 Müller, "Letter," 108.

150 Müller, “Letter,” 168.

151 Müller, “Letter,” 147.

152 Müller, “Letter,” 186-213.
} 
Müller's rather hasty grouping of such numerous languages all over Eurasia was among the biggest weaknesses of his theory. His assumption of nomadic languages changing rapidly made him to take the liberty to relate vastly heterogeneous languages. Even if one accepts his premise that Turanian languages are to be classified according to different standards, the very morphologies of the southern languages differ significantly. The Taïc and Himalayan Bhotiya languages, for instance, use prefixes before verbal roots - a pattern that is absent in the northern division. This is in addition to the paucity of correspondences between the vocabularies of the so-called northern and southern divisions. Müller failed to note the minimal criteria that nomadic languages should meet in order to be genealogically related. He also fell short of giving clear explanations for when a language ought to be considered "nomadic" as opposed to "state." These

drawbacks, however, do not diminish the importance of some key questions Müller raised through his Turanian theory. His questioning of universally-similar patterns of linguistic change in both nomadic and settled societies, and his disentangling of linguistic and racial divergence could serve as food-for-thought to scholars in our own time.

\section{Some conclusions}

Working in the tradition of earlier European linguists writing about non-IndoEuropean languages, Müller redefined what features united the Turanian family and what languages might be included in it. He brought in the Romantic worldview he derived from his upbringing in Dessau, and his subsequent experiences at Leipzig, Berlin, Paris, and England to linguistic scholarship in the 1850 s — when he was a young, up-andcoming philologist. His mentor Bunsen's influence, his Christian universalism, and his 
own interest in promoting the study of foreign languages for intercultural dialogue in the imperial context led him to write on the Turanian languages. Müller went much further than his predecessors in adding a civilizational dimension to the morphological evolution of languages towards inflections. While Castrén too identified nomadism, agglutination, and some resemblances among words unifying the "Altaic" family, Müller took the idea of nomadism as a central organizing principle to understand languages and focused on how the different social structures were reflected in language. His views on these hierarchical civilizational stages were colored by Victorian assumptions about less advanced peoples without modern states and high culture. Nevertheless, his critique of universal criteria like sound shifts for classifying all languages suggests an element of Humboldtian linguistic relativism in his thoughts, where the emphasis is on how languages differ from one another. This issue of universals remains an enduring concern in twenty-first-century linguistics, to which Müller's relativistic approach might be insightful. Müller was also insightful in distinguishing linguistic and racial classifications, saying that the two need not overlap. His theory eventually fell short by grouping too heterogeneous languages like the Southern and Northern Asian language groups in the same catch-all family. However, he continued to bring up this theory in his broader thoughts on various human sciences. Chapter 3 details his lectures and writings between 1855 and 1880, and some critiques of his Turanian theory by his contemporaries. 


\section{CHAPTER 3}

\section{The Geological Stratification of Language: The Turanian Theory in Müller's Construction of the Sciences of Language, Mythology, and Religion (1855-80)}

In the successive strata of language, we have in fact, as in Geology, the very thread of Ariadne which, if we will but trust to it, will lead us out of the dark labyrinth of language in which we live, by the same road by which we and those who came before us, first entered into it. The more we retrace our steps, the more we advance from stratum to stratum, from story to story, the more shall we feel almost dazzled by the daylight that breaks in upon us; the more shall we be struck, no longer by the intricacy of Greek or Sanskrit grammar, but by the marvellous simplicity of the original warp of human speech, as preserved, for instance, in Chinese.

-Müller, "Lecture on the Stratification of Language," 1868, p.13.

The "Turanian" aggregation, as established by [Müller], and widely accepted on his authority, has for a generation been a stumbling-block in the way of science.... The classification was always a groundless and unscientific one, a classification of ignorance, or a practical erection of the absence of family likeness into a family tie. It was a step backward, in which our author dragged with him a great many weak or illinformed followers; and these, unfortunately, will be slow in retrieving it; the name Turanian will probably long continue, as it has long been, one of the watchwords of sciolism.

—William D. Whitney, Max Müller and the Science of Language, 1892, p.49.

The couple of decades following Müller's initial exposition of the Turanian language family in the mid-1850s oversaw many changes to his personal and academic life. Both his early mentors Eugene Burnouff and Christian von Bunsen, who had helped Müller in the pursuit of Sanskrit studies, died by the end of that decade. As Müller was continuing his Taylorian Professorship in European linguistics and literature, he endured a difficult love affair with an English girl named Georgina Grenfell before marrying her in 1859 . Though mutually in love, they had to overcome Georgina's father's disapproval of their marriage owing to his doubts about Müller's financial status and Christian faith.

The couple was happy to have four children born to them in the 1860 s, but the two eldest 
daughters died young in the 1870s and '80s. Professionally too, Müller had mixed luck with his loss of an election for an Oxford Sanskrit professorship in 1860, but with a rise to fame following his linguistics lectures at the prestigious Royal Institution in London. Müller subsequently reoriented his career from purely Sanskrit studies to general theories of language, myths, and religion, with a noticeable shift to comparative religion in the 1870s. He associated himself with the less dogmatic and liberal Broad Church.

Though Müller did not produce any new treatises on the Turanian languages in this period, he continued to include his idea of a catch-all Turanian family in his general linguistic theories. His international reputation enabled the dissemination of the Turanian concept. He did not give up the theory that nomadic languages could be genealogically related even if they seemed far more heterogeneous than Aryan and Semitic languages. ${ }^{153}$ While he retained the evolution of languages from the isolating to inflectional classes, Müller used new metaphors after 1855 for understanding the historical morphologies of languages - he began turning to geology and paleontology to analogize linguistic change. His earlier conception of three social stages of family, nomad, and state languages did not disappear, but he now saw the morphological stages resembling geological strata in the Earth's crust formed at varying temporal phases. Müller's biographer Lourens van den Bosch notes that Müller went on a casual excursion to the Malvern Hills in 1855 with the geologist John Phillips, who explained strata and fossils to him. ${ }^{154}$ Müller extended his analogy to imagine that the lower-most stratum of language was isolated roots

\footnotetext{
153 Friedrich Max Müller, Lectures on the Science of Language Delivered at the Royal Institution of Great Britain in 1863, vol.2 (New York: Scribner, Armstrong, \& Co., 1873), 32-33.

154 Bosch, Friedrich Max Müller, 210.
} 
constituting the earliest human speech. Differing from Charles Darwin, he attributed the roots of language to an abstracting faculty unique to humans and absent in animals.

One field where Müller saw the linguistic stratification metaphor helpful was mythology, which many of his Victorian contemporaries thought of as irrational ancient stories about humans, nature, gods, and heroes. Müller's familiarity with Greek, Latin, and Sanskrit philology inspired him to consider how the comparative study of languages could aid scholars to make better sense of the origin of myths. He found many fantastic, violent, and sexually promiscuous elements in classical mythology distasteful, and saw them as an inevitable stage of a "disease of language" in history. Yet, his point was that myths had their earliest origin in metaphors that primitive people used to describe natural phenomena, and were rational in the beginning. ${ }^{155}$ He relied on his linguistic theory that the earliest linguistic stratum had isolated and meaningful roots, whose original meanings were forgotten as languages became inflectional. This forgetting process led later people to misconstrue the metaphorical early use of roots literally, and create numina (beings like gods and heroes) out of nomina (names). For instance, the root div that initially metaphorically described the sky as a bright thing degenerated into myths about actual bright beings in the sky like Dyaus, Zeus, Jupiter, and Tyr in Aryan languages. ${ }^{156}$ Müller also saw the Turanian stratum susceptible to the disease of myths with a few differences. Besides linguistics and mythology, the major new area of science that Müller passionately pioneered from the late-1860s was the comparative study of religions. As he

\footnotetext{
155 Bosch, 246.

156 Müller, Science of Language, vol.2, 444.
} 
saw the languages and beliefs of a people closely reflecting each other, his classification of religions resembled his grouping of languages into the Aryan, Semitic, and Turanian branches. ${ }^{157}$ As in linguistics, Müller treated religions historically and stressed the study of etymologies of religious concepts (like the names of deities) within linguistic families. He supposed religions to have passed through several strata in the past, experiencing both degeneration and progress along the way. For Müller, religions were like myths in having a rational beginning based on what he termed "a perception of the infinite." $158 \mathrm{An}$ intuitive sense of an infinite "Beyond" lying behind finite phenomena accessible to humans gave rise to beliefs in deities inhabiting the heavens. Polytheism was a degenerate intermediary stage corresponding to the mythological stage, while the most advanced religions evolved to be monotheistic or panentheistic. Müller placed the Turanian religions of the Mongols and Finns in the more primitive strata where people worshipped multiple spirits of nature and ancestors. Nevertheless, he compared religions with reverence to non-Christian religions and tried to uncover their shared foundations.

In all these theories of language, mythology, and religion, Müller relied on geological strata and fossils as analogies to explain changes and continuities in these human phenomena. He popularized the Turanian family as a distinct stratum representing the agglutinating stage, and argued that one must not always expect all linguistic and religious strata to obey uniform laws. ${ }^{159}$ This approach continued his earlier Romantic

\footnotetext{
157 Friedrich Max Müller, Lectures on the Science of Religion (New York: Scribner, Armstrong, \& Co., 1872), 83-144.

158 Friedrich Max Müller, Lectures on the Origin and Growth of Religion, as Illustrated by the Religions of India (London: Longmans, Green, \& Co., 1879), Ch.1.

159 Müller, Science of Language, vol.2, 32-33.
} 
inclination to see languages varying in reflection of the spirit of the society they are spoken in. The geological metaphors further supported his pitch for language, mythology, and religion to be studied as comparative sciences on par with the natural scienceswhich were making significant discoveries in the wake of Darwin's Origin of Species. The Turanian "stratum" was now a tool for Müller, in his scientific model for understanding the origin and growth of languages, as an intermediary stage in the hierarchical evolution of speech. He used the strata analogy to push for broadening the human sciences beyond the study of a few literary languages. However, he had hostile critics like the American Sanskritist William D. Whitney, who attacked Müller's Turanian theory from a sociological view of language. The late-1860s also saw the "Ugric-Turkic Battle" (Az ugor-török háború) in Hungarian linguistics, a debate on whether the Magyar language was closer to Finno-Ugric or Turkic. Müller did not participate in these debates, which were centered on Northern Eurasian languages. These debates laid the foundation for later Pan-Turanian nationalists who would challenge Müller's hierarchical stages of ethnolinguistic evolution and his designation of Southern Asian languages as Turanian.

\section{Müller, his Family, and the Human Sciences (1855-80)}

As Müller was continuing in his position as a Taylorian professor at Oxford after his mentor Bunsen's departure from England in the mid-1850s, he found the university getting polarized on religious and political issues. ${ }^{160}$ These conflicts would affect both his personal and academic life in the coming decades. Initiated by William Gladstone, the Oxford University Act of 1854 secularized the university by ending religious restrictions

160 Bosch, Friedrich Max Müller, 59-60. 
on student admissions and on membership in various university councils. This legislation exacerbated tensions between conservative Anglican theologians and the liberal Broad Church, with the former resentful of the latter gaining an upper hand through the secular reforms. Müller, as a Pietistic Lutheran, was supportive of a liberal and personal reading of scriptures, and was in touch with controversial Broad Church thinkers like Benjamin Jowett and James Froude. ${ }^{161}$ This got him into trouble when he was courting Georgina, whose father was unwilling to let her marry a man whose Christian faith was unclear and who was not so wealthy. Müller defended his faith to Georgina in an anonymous German novella he published entitled Deutsche Liebe. It showed his respect and faith in the "simple" teachings of Christ as opposed to the rigid doctrines of the later church.

It was only after three frustrating years that Georgina's father agreed to let Müller and Georgina marry each other in 1859. Müller's novella had dealt with a fictitious poor commoner in Dessau courting a disabled princess he had played with as a child. ${ }^{162}$ Though the two loved each other and shared a similar anti-dogmatic Christian faith, they were separated by class and the princess's illness. Her death prevented their marital union, though she had given him her consent. Müller feared a similar tragedy in his real life, but matters took a surprising twist when Georgina fainted at a concert upon seeing Müller entering the hall. The doctor's grave report about Georgina's emotional suffering finally led her father to consent to her marriage. This episode suggests that religious faith was important in the mid-Victorian context, and that dissent from orthodoxy could cause

\footnotetext{
161 Bosch, 46.

162 Friedrich Max Müller, Deutsche Liebe (German Love): Fragments from the Papers of an Alien (London: W. Swan Sonnenschein \& Co., 1884; orig. 1857).
} 
problems. Yet Müller was not interested in theological dogmas, though he held on to his Christian faith. ${ }^{163}$ For Müller, one's personal communion with God was more important than liturgy, rituals, and sacraments. This colored his later theories of comparative religion that focused more on faith than rituals. Müller also held a Romantic belief that religions were originally pure and decayed over time owing to corrupt religious leaders.

Müller focused primarily on linguistics and philology until the end of the 1860 s, although he had already done some writings on religion too by then. ${ }^{164}$ His linguistic works were shaped by the contentious religious and political climate, especially after Darwin's publication of the Origin of Species in 1859. The challenge that the natural selection theory posed to the special place of humanity in God's plan for the world deeply troubled Müller. He tried to defend the uniqueness of human beings in his famous linguistics lectures at the Royal Institution by arguing that only humans possess language —our "Rubicon" that "no brute will dare to cross." 165 These were lectures attended by such illustrious people as John Stuart Mill, Michael Faraday, and Charles Lyell, and later given an audience by Queen Victoria herself. ${ }^{166}$ Here, Müller argued that languages depend on a generalizing faculty unique to humans that produces word roots. He then brought in the geological stratification analogy to explain how these roots reached the

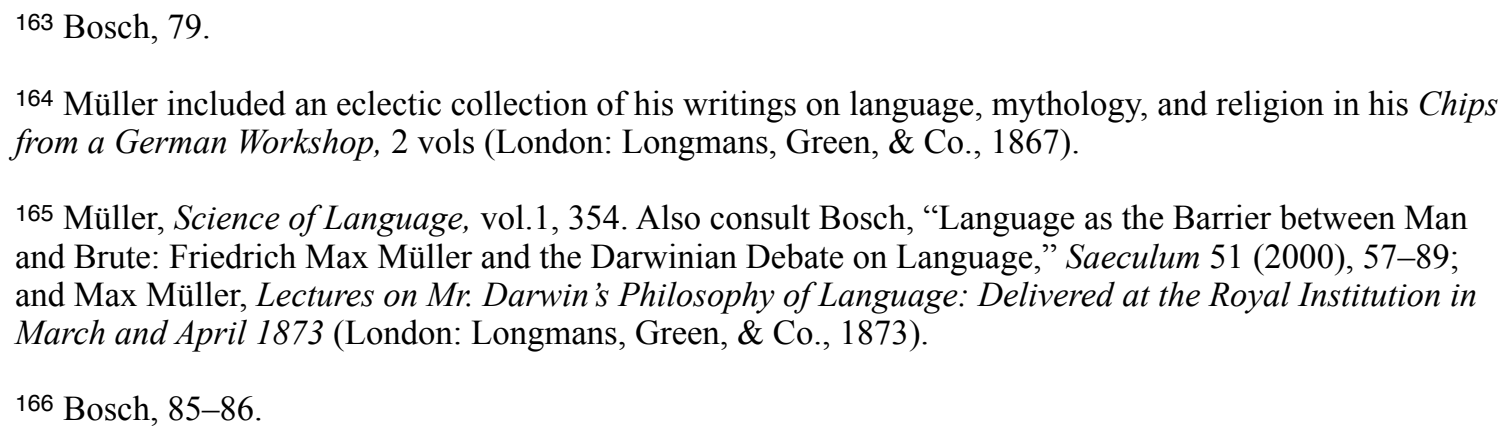
from a German Workshop, 2 vols (London: Longmans, Green, \& Co., 1867).

165 Müller, Science of Language, vol.1, 354. Also consult Bosch, "Language as the Barrier between Man and Brute: Friedrich Max Müller and the Darwinian Debate on Language," Saeculum 51 (2000), 57-89; and Max Müller, Lectures on Mr. Darwin's Philosophy of Language: Delivered at the Royal Institution in March and April 1873 (London: Longmans, Green, \& Co., 1873).

166 Bosch, 85-86. 
inflectional stage. His theories led to a vigorous counter-attack from Darwin in his Descent of Man (1871), wherein Darwin argued that language was not an insurmountable gap between humans and animals. Yet Müller never gave up his human uniqueness view. Müller's linguistic opposition to Darwinism did not, however, mean that he was opposed to science in the name of religious or philosophical dogma, as his rivals like Whitney claimed. The latter mocked him saying that Müller "thought to stop Darwinism by quoting Kant against it" and aspired to "see science governed by the authority of the philosophers." ${ }^{.167}$ While Müller did use his various ideological influences to defend his claim that humans are too special to have evolved from animals, he did not reject natural selection outright and even used metaphors of struggle for life in his account of formation of the earliest word roots. ${ }^{168}$ Besides, he intended to develop the sciences of language, mythology, and religion with the goal of empirically tracing their historical changes. This was the spirit in which he was evoking geological metaphors for linguistic change. It would be too simplistic to consider him as an obstinate religious ideologue obstructing the path of science. Müller himself was, at the same time, subject to suspicion from Anglican theologians owing to his Broad Church connections and support for Essays and Reviews (1860) - a text by liberal clergymen critiquing traditional Christian dogma in light of modern science. In consequence, Müller lost the ecclesiastical vote share to a more evangelical professor in the election for a Sanskrit professorship that year.

\footnotetext{
167 William Dwight Whitney, Max Müller and the Science of Language (New York: D. Appleton \& Co., 1892), 75 .
}

168 Müller, Science of Language, vol.1, 387. 
The tense battles between conservative theologians and Darwinians in the $1860 \mathrm{~s}$ and his own unpopularity among conservative circles kept Müller wary of publishing on religion during that decade. But by 1870, Müller was rewarded at Oxford with a Chair of Comparative Philology position for his famous linguistics lectures and his editorial work on the Rigveda. He then felt more comfortable giving public lectures on religion, though he received hostile reactions from theologians for his advocacy of the comparative approach. ${ }^{169}$ Müller's belief was that to best respond to atheism and skepticism about faith, one must not obstinately cling to Christian doctrines but must scientifically study all religions comparatively to determine elements common to all. He stressed the study of original canonical texts of major religions to uncover their uncorrupted earliest forms as opposed to later accretions. ${ }^{170}$ This approach stemmed from his Romantic view that the original cores of all religions were pure and could withstand assaults from materialists that petrified doctrines could not. This motivated him, besides giving lectures, to organize a team of scholars to do the mammoth task of publishing what eventually became the fifty-volume Sacred Books of the East in English translation. This project began in 1876.

In his writings on religion, Müller borrowed much from his linguistic theories and stressed etymological comparisons of religious ideas within linguistic families. He was not above seeing some religions as more decadent or advanced than others, but he was more sympathetic to the so-called primitive religions than many of his contemporaries. Departing from the narrative of any one chosen people of God, Müller saw all religions

\footnotetext{
169 Bosch, 97.

170 Müller, Science of Religion, 20.
} 
containing some truth and having access to God's revelation in nature. Stressing the original purity of religions, he rejected the theories of Edward Tylor and Herbert Spencer that "savage" religions of the nineteenth century based on "fetishism" were barbaric remnants of the earliest human faith. ${ }^{171}$ For Müller, even such religions of Africa and Australia showed traces of the universal truth. His tolerant approach met with hostility from some theologians, who objected to including Christian texts on par with those of other religions in his Sacred Books of the East. ${ }^{172}$ Regardless, Müller continued pushing for the scientific study of religions in his 1878 lectures at Westminster Abbey. These lectures came a year after the death of his eldest daughter Ada, which left him in deep sorrow. This pushed him deeper into a search for meaning through comparative religion. This period between 1855 and 1880 included some of Müller's most productive years that propelled him to international fame and dragged him into controversies. While his primary interest was in Indo-European languages and religions, his quest for general theories and grand narratives led him to continue bringing up his Turanian theory in his models of historical change. The strata of sedimentary rocks in geological formations over hundreds of millennia, which he had observed at the Malvern Hills and read about in Lyell's books, inspired him to explain changes in human phenomena in geological terms. As Müller wrote extensively on language, myths, and religion in this period, one can find geological metaphors of stratification scattered across his major treatises and shorter articles. Two key articles in which he elaborated on this metaphor were "On the

\footnotetext{
171 Müller, Origin and Growth of Religion, 54-130.

172 Bosch, 118.
} 
Stratification of Language" (1868) and "On Curtius' Chronology of the Indo-Germanic languages" (1875). Müller's attention to these parallels between geology and the human sciences derived from the historical emphasis shared by these diverse disciplines in the nineteenth century. His attempt to show the closeness of his fields to the natural sciences suggests an anxiety to have his work recognized as valid science in an age when he had to contend with attacks from both Darwinians and conservative theologians.

\section{The Stratification Discourse in Müller's Linguistics}

Müller was aware of the work done by geologists from the eighteenth century to uncover knowledge about the history of the earth, the flora and fauna of earlier epochs from fossils, and minerals for mining purposes. The idea of the earth's crust formed over long geological epochs in multiple horizontal layers of deposits called strata appealed to Müller as an analogy for linguistic change. The geological strata resulted from temporal differences in the earth's environment and of the water-flow consequently depositing sediments that reflected such differences between geological epochs. Like the earth's crust, Müller saw languages formed over many epochs that each "deposited" different features on them. ${ }^{173}$ These deposits took the form of three horizontal linguistic "strata," which corresponded to the morphological classes of isolating, agglutinating, and inflectional languages. Imagining these classes as strata, Müller continued the nineteenthcentury tradition from Bopp and Humboldt of seeing a linear progression from isolating languages like Chinese to inflectional ones like the Aryan and Semitic. It implied that

\footnotetext{
173 Friedrich Max Müller, On the Stratification of Language (London: Longmans, Green, Reader, and Dyer,
} 1868), 2. 
inflectional word-formations were not the earliest linguistic constructs that humans developed, but rather the result of a systematic evolution through time. He claimed:

Unless Sanskrit and Greek and Hebrew had passed through the agglutinative stratum, nay unless, at some time or other, they had been no better than Chinese, their present form would be as great a miracle as the existence of chalk (and the strata associated with it) without an underlying stratum of oolite (and the strata associated with it;) or a stratum of oolite unsupported by the trias or system of new red sandstone. ${ }^{174}$

Müller also continued his own earlier idea of a linear narrative of family, nomad, and state languages, suggesting that inflectional languages must have once been like Chinese.

Among these three strata of languages, the earliest isolating one has independent roots that each have a particular meaning. Müller treated it in the same sense as the term "family" languages, and added the algebraic notation $R R$ where each $R$ is an independent root. ${ }^{175}$ Though languages like Chinese and Tibetan remain in this state to modern times, others passed into the agglutinating stage where some roots lost their independent meaning and became mere terminations. The affixes are meaningful only when added to bases. These languages still retain independent roots for their bases, and are represented by $R+\varrho, \varrho+R$, or $\varrho+R+\varrho$. Here, $\varrho$ stands for the affix that has no meaning of its own. This is the Turanian stratum of languages, which precedes the final inflectional stage where both the base and affix no longer have independent meanings. The two are fused together into one "indistinguishable mass" and are denoted by re, or, or or@, with $\mathrm{r}$ being the base fused with the affix. ${ }^{176}$ Müller recognized that no language always has words

\footnotetext{
174 Müller, Stratification of Language, 21.

175 Müller, Stratification of Language, 16.

176 Müller, Stratification of Language, 16.
} 
that fall purely into one category. ${ }^{177}$ There could be agglutinating features in inflectional languages like the Greek word "Nea-polis" - where the root "polis" retains its independent meaning. Yet he argued that while agglutination need not entirely stop in the inflectional stratum, there is a one-way evolution from isolating to inflectional strata.

A central challenge Müller faced with the strata metaphor for linguistic change was in proving that inflectional languages were once isolating and agglutinating. For this, it was important to establish other morphologies as temporally prior to inflection. Müller had critics like the polygenist August Pott, who, in his Etymologische Forschungen (1871), attacked the idea that all languages were once isolating. Pott claimed the inherent superiority of Aryan inflectional languages and set impermeable borders between various morphologies. Müller, as a monogenist, tried to counter Pott by giving examples of inflections in Aryan languages that could be traced back to independent words. ${ }^{178}$ One instance was the English and German terminations "-ard" or "-art" as in "drunkard," “Gerard," and "Bernard," whose etymologies led back to the Old High German word "hart" with an independent meaning of "strong." Müller asserted that many terminations today like "-dom," "-ship," and "-ment" could be proved to have been words of their own right in the past. He was aware that the origins of many such terminations were not yet deduced, but remained convinced that inflectional languages evolved from the other classes. ${ }^{179}$ He stressed that languages need not always be locked up in one class.

\footnotetext{
177 Müller, Stratification of Language, 19.

178 Müller, Stratification of Language, 23-31.

179 Müller, Stratification of Language, 21-22.
} 
The Turanian stratum formed the intermediate stage in Müller's chronological arrangement of languages, and he mostly gave it the same characteristics as the nomad group of his former classification. He again argued that scholars should not look for the same close parallels as between Greek and Sanskrit while classifying agglutinating languages like the Finnic, Turkic, Mongolic, and the South Asian Taïc, Malaïc, and Tamulic groups. As he saw many of these cultures lacking the literature, laws, and political structures of the Aryan and Semitic families, he expected the former's languages to be far wilder in dialectal splintering over time and in their lack of preservation of older linguistic features. Müller added the geological analogy to language change as below.

Language, though its growth is governed by intelligible principles throughout, was not so uniform in its progress as to repeat exactly the same phenomena at every stage of its life. As the geologist looks for different characteristics when he has to deal with London clay, with Oxford clay, or with old red sandstone, the student of language, too, must be prepared for different formations.... Then to apply indiscriminately to the lower stages of human speech, to the agglutinative and radical, the same tests which have proved successful in the inflectional, would be like ignoring the difference between aqueous, igneous, and metamorphic rocks.... To call for the same evidence in support of the homogeneousness of the Turanian languages, is to call for evidence which, from the nature of the case, it is impossible to supply. As well might the geologist look for fossils in granite! The Turanian languages allow of no grammatical petrifactions like those on which the relationship of the Aryan and Semitic languages is chiefly founded. 180

Though the Finnic, Mongolic, and Taïc groups might be so widely scattered and linguistically varied, Müller confidently used their agglutinating morphology to unite them into a genealogical group. He imagined the agglutinating stratum to have emerged at an earlier stage in the evolution of languages than the inflectional one. Just as the earth's environment varies from epoch to epoch and produces diverse strata, Müller took

180 Müller, Science of Language, vol.2, 32-33. 
the case to language and claimed that one must allow for a different process to have been at work in the prehistoric stage when agglutination first emerged.

Müller emphasized the Turanian stratum not just to establish its common descent, but also to push for the scientific study of languages without literatures to understand the nature and prehistory of language. He regarded the literature-rich Aryan and Semitic languages as just a thin tertiary stratum overlaid on a vast interior filled with exotic and possibly "wild” languages. While Müller spent most of his life focusing on the Aryan family, he was aware of the importance of the other strata if one were to reconstruct a general history of language as part of a "Science of Man." With this aim, he wrote:

In the natural history of speech, writing, or what in early times takes the place of writing, oral tradition, is something merely accidental. It represents a foreign influence which, in natural history, can only be compared to the influence exercised by domestication on plants and animals.... However important the effects produced by this artificial domestication of language may be ... in the eyes of a student of language, Sanskrit, Greek and Latin, Hebrew, Arabic and Syriac, are what a student of natural history would not hesitate to call "monstra," unnatural, exceptional formations which can never disclose to us the real character of language left to itself to follow out its own laws. ${ }^{181}$

The Turanian stratum, as opposed to the "domesticated" inflectional languages, could be valuable to learn about language in its earlier stages when it lacked literary sophistication. This might seem to put Müller in the same class of Victorian scholars who used modern "savages" as the model for inferring about prehistoric humans. Yet Müller was different by showing sympathy for all human languages, which he imagined to have originally emerged out of the unique human capacity to reason and generalize. Turanian languages, though not so advanced as the Aryan ones in his view, were also important for science.

181 Müller, Stratification of Language, 9-10. 
The threefold strata figured prominently in Müller's vision for promoting the science of language along the lines of the physical sciences. In his famous 1861 lectures at the Royal Institution, he argued for his own theories of language based on the leading works in linguistics then. He intended to lead linguistics towards the highest frontier all sciences were headed for. Drawing on the philosopher of science William Whewell, Müller imagined the history of all sciences to ideally consist of three stages - the empirical, classificatory, and theoretical phases. ${ }^{182}$ This was not an inevitable path every science actually followed in history, as he found multiple cases of a priori speculations preceding empirical work. Yet he saw this as a normative path for all sciences, which should each begin by compiling observations from the natural world, and then classifying them to discover an underlying order behind the chaos. The last stage would be a theoretical inquiry into the meaning of the whole framework. This historical vision for the sciences reflected his faith in God's orderly plan for the world. ${ }^{183} \mathrm{He}$ thought of linguistics advancing from the classificatory stage (after Jones, Grimm, and Bopp) to the theoretical stage, where the "strata" of languages could help build an overarching theory.

One of Müller's central contentions about the theoretical stage in linguistics was that language could be studied as a "physical" science like geology, physics, and natural history. Roughly classifying all phenomena into the works of God (like nature) and works of humans (like art and society), he contended that "physical" sciences dealt with the former and "historical" sciences with the latter. Müller did not argue for language being

\footnotetext{
182 Müller, Science of Language, vol.1, 15.

${ }^{183}$ Müller, Science of Language, vol.1, 26.
} 
of divine origin, but thought that linguistic change worked out owing to factors beyond individual human control and deserved to be classed as a natural phenomenon that exhibited "growth" rather than a "history" over time. ${ }^{184}$ It might seem counterintuitive that Müller saw language as so unique to humanity and yet did not treat linguistics as a strictly "human" science - a point which his contemporaries like Whitney were quick to critique. It was his conception of large-scale natural forces working to change languages that led him to think of linguistics as a physical science. This was different from the Schlegels' and Schleicher's views of language as a living organism, which Müller rejected as fanciful mythology. ${ }^{185} \mathrm{He}$ used his geological metaphors comparing language to the earth's crust to illustrate how factors beyond human will were acting on languages.

This imagery of the physical sciences factored into the processes that Müller proposed to account for the transition of languages from the isolating to inflectional strata. The two major linguistic processes he theorized were phonetic decay and dialectical regeneration. ${ }^{186}$ The former involved some words losing the original meaning they supposedly possessed in their primordial state and becoming mere affixes. This phonetic decay was what Müller conceived as particularly affecting the inflectional languages in their evolution from the isolating and agglutinating stages. It also meant that some languages like Chinese were resistant to phonetic decay, and others like the Turanian ones resisted the decay of their bases while their affixes lost independence. His

\footnotetext{
184 Müller, Science of Language, vol.1, 49, 76.

185 Müller, Science of Language, vol.1, 51.

186 Müller, Science of Language, vol.1, 51-66.
} 
reasoning for the occurrence of such decay in Aryan languages was articulatory simplification through the deletion of consonants and their clusters. ${ }^{187}$ Müller found many such examples in the development of French from Latin-père from pater, chaine from catena, and fée from fatum. He traced "decayed" words like viginti (twenty) in Latin to its roots in "two" and "tens"- which languages like Chinese had preserved in the word for twenty: "eul-shi" or "two tens." Müller contended that phonetic decay in some languages was a physical process beyond human control.

The other long-term physical process acting on language, for Müller, is dialectical regeneration, which has a greater effect on the agglutinating Turanian and isolating languages. It relates to the invariable existence of languages in the form of mutuallyintelligible dialects, even in cultured societies. Müller saw the proliferation of languages into dialects particularly rapid in languages spoken by peoples without literatures and states. ${ }^{188} \mathrm{He}$ found this perception supported by numerous accounts of European travelers and missionaries to Asia, the Americas, and Africa. They reported about how quickly languages without written texts changed and how their dialects lost mutual intelligibility within a generation. These narratives emboldened Müller to argue that rapid divergence and mixing of dialects characterized the Turanian language family. This went together with his claim that different strata of languages may admit different processes at work in linguistic change. Nevertheless, he emphasized that all languages —including the highly

\footnotetext{
187 Müller, Science of Language, vol.1, 73.

188 Müller, Science of Language, vol.1, 61-65.
} 
literary ones - have dialects, and even romanticized how such changing dialects were the feeders of literary languages and kept the growth of languages continuing. He claimed:

[Literary dialects] are like stagnant lakes at the side of great rivers. They form reservoirs of what was once living and running speech, but they are no longer carried on by the main current. At times it may seem as if the whole stream of language was absorbed by these lakes, and we can hardly trace the small rivulets which run on in the main bed. But if lower down ... later in history, we meet again with a new body of stationary language, we may be sure that its tributaries were those very rivulets which for a time were almost lost from our sight. Or it may be more accurate to compare a classical idiom with the frozen surface of a river, brilliant and smooth, but stiff and cold. It is mostly by political commotions that this surface of the more polite and cultivated speech is broken. ${ }^{189}$

Like phonetic decay, Müller thought of dialectical break-up as a physical process, and used geological metaphors to illuminate the parallels with the natural sciences.

Alongside these theories of linguistic change, one theoretical problem Müller considered significant was the earliest linguistic stratum and the origin of language. $\mathrm{He}$ treated this issue as the base on which his other linguistic strata rested, and one that formed the crucial "Rubicon" between humans and animals in his debates with Darwin. Müller was confident that all languages had a common origin and could be traced back to a few hundred primordial roots - the simplest elements of words carrying meaning. In this sense, he called language a "thrifty housewife" who supplies all the lavish needs of her "husband"- the human mind — with a few roots. ${ }^{190} \mathrm{He}$ speculated on the origin of these earliest roots, and rejected Darwinian explanations of onomatopoeia (the "Bowwow theory"), interjections (the "Pooh-pooh theory"), and other human imitations of natural sounds for the origin of language. For Müller, roots emerged from the unique

\footnotetext{
189 Müller, Science of Language, vol.1, 68.

190 Müller, Science of Language, vol.1, 266.
} 
human ability to think generally about an object's properties and to give relevant names. He gave many examples of the earliest known roots of words expressing general ideas like the "measurer" for moon and the "ploughed" for the earth. ${ }^{191}$ His problem, however, was the huge time gap between the actual origin of language and these known roots.

In all these discussions on language and its history in the 1860 s and 70 s, the stratification metaphor was a key element Müller used to popularize his ideas. Just as the earth's crust was the result of different kinds of deposits in various geological epochs, language too was temporally stratified. The Turanian stratum was important for Müller as an "other" in relation to the inflectional languages. It occupied a more primitive layer than the literature-rich inflectional languages, and embodied the ever-shifting lifestyle of nomads. Yet it is too simplistic to say that Müller was merely dismissive of this stratum as a primitive one. He hoped to broaden linguistic study to include such languages as he interpreted them to be in a more "natural" state than literary languages. He also romanticized the importance of dialects in tracing the growth of languages, and saw the strata of languages as the "thread of Ariadne" in helping one understand the mysterious early history of language. ${ }^{192}$ Overall, his analogies with geology were aimed at bolstering the scientific credentials of his theories and arguments for large-scale physical forces working on languages. Müller's historical approach continued in his sciences of mythology and religion, where the Turanian family held a similar place as in linguistics.

\footnotetext{
191 Müller, Science of Language, vol.1, 379.

192 Müller, Stratification of Language, 13.
} 


\section{The Turanian Stratum in Müller's Comparative Mythology and Religion}

It was the close relationship between language and thought in Müller's theories that led him to consider the impact language has on aspects of thought like mythology and religion. As in linguistics, one can find Müller employing the strata analogy to explain the origins and prevalence of myths and religions in human history. With regard to myths, he was especially disturbed by the seemingly irrational, sexually promiscuous, and violent patterns even in the myths of civilized people like the ancient Greeks. ${ }^{193}$ Müller hoped to explain this paradox using the tools of comparative linguistics to compare national mythologies with those of their cognate languages, particularly by tracing the etymologies of the chief mythical gods and heroes. He argued that myths were the product of a particular era - mostly in the ancient period of Aryan cultures — which he called the "mythopoeic period."194 This age did not always occur at the same time in all cultures, and he imagined some primitive cultures still living in the mythopoeic period in the nineteenth century. He dated this period as a stratum after the first formation of inflectional languages but preceding the emergence of literature, religion, laws, and centralized states. It was a peculiar stratum in which language troubled human thought.

Müller's unique conception of myths as a "disease of language" came from his idea that such stories as Hades abducting Persephone to the underworld or Apollo chasing Daphne were originally metaphors whose initial meanings were forgotten over time. As Müller thought of the earliest language as a "thrifty housewife" who used a few hundred

\footnotetext{
193 Müller, Comparative Mythology: An Essay; originally published in 1856 (London: George Routledge \& Sons., Limited, 1909), 1-5.

194 Müller, Comparative Mythology, 12.
} 
roots to express boundlessly numerous ideas, he emphasized metaphors as crucial to early languages. ${ }^{195}$ People extended the few earliest roots, which often had concrete meanings, to metaphorically express more abstract concepts. For instance, the root "to shine" could be used as a name for numerous bright and shiny things like the sun, the moon, the sky, the stars, the day, and lightning. The same root could also be applied to animals with shiny skin or fur like horses and bears. In this manner, the Indo-European root "ghar"meaning bright — came to refer to both the sun's rays and horses. Over time, people forgot that the initial similarity of names between rays of light and horses was metaphorical, and confused the two to conjure a myth that the sun god Helios had many horses. ${ }^{196}$ For Müller, this confusion of names derived from the same radical to form myths was common in isolating and agglutinating languages, where the root was distinctly visible. ${ }^{197}$

While the mixing up of the meanings of words from the same root (or "radical metaphor") was one mechanism that generated myths, another was "poetical metaphor." It involved an idea that most myths had their origins in creative metaphors for natural phenomena like the sunrise, thunderstorms, earthquakes, or eclipses. In the earliest stage of language, people were fascinated by regularly recurring natural events like the sunrise that suggested the orderliness of the cosmos, and by irregular and violent events like thunderstorms that imparted a sense of fear and mystery. ${ }^{198}$ Using the few early roots available, people tried to imaginatively describe these natural phenomena with metaphors

\footnotetext{
195 Müller, Science of Language, vol.2, 368-371.

196 Müller, Science of Language, vol.2, 387-390.

197 Müller, Science of Language, vol.2, 376.

198 Müller, Science of Language, vol.2, 537-543.
} 
that often anthropomorphized nature. They represented complex items through analogies with familiar ones. For example, they might have likened the sun's rays of light to human hands, the stars to eyes or flowers, the sunrise to birth, and the wind's rustling to a song. As generations passed, people lost track of the idea that these comparisons were mere metaphors, and interpreted them literally to produce myths. They now thought of the sun as an actual person with golden hands, the stars as the all-seeing Panoptes, and the wind as a musician, and weaved them into narratives. ${ }^{199}$ Müller stressed regular solar events, rather than irregular storms and calamities, as the meaning behind myths.

These radical and poetical metaphors become myths during the temporary "mythopoeic" period that Müller saw all cultures passing through at some point. Müller likened this era to the geological "Eocene period" that formed an intermediate stratum in the earth's crust between the Paleocene and Oligocene strata of the Cenozoic era. ${ }^{200} \mathrm{He}$ contended that myths were explainable in the form of scientific laws that showed how languages caught the mythological "disease." As he supposed myths to be a temporary phenomenon, he expected them to eventually give way to "higher" monotheistic religion. This was a deterministic reading of history that interpreted religions as the culmination of repeated attempts by humanity to understand the divine, after inevitably falling into the trap of mythology along the way. He drew on examples from Greek mythology where, despite the numerous gods who often caused mischief and exhibited human vices, there were glimpses of profound religion when people called on the all-powerful Zeus to

\footnotetext{
199 Müller, Science of Language, vol.2, 397-398.

200 Müller, Comparative Mythology, 12.
} 
protect them. ${ }^{201}$ Greek myths were originally nominal metaphors for nature—like "Zeus" was a name for the sky—-that came to be mistaken for deities, but eventually pointed the way to monotheism. Müller treated Greek polytheism as a preparation for Christianity. ${ }^{202}$

The mythopoeic stage was not unique to Indo-European languages, and Müller recognized that the Turanian cultures had produced numerous myths as well. Though his chief attention was reserved for Greek, Vedic, and Norse myths, he tried to demonstrate that Turanian myths also conformed to his theories. As with languages, he did not expect to find close similarities as between Aryan myths among those of the widely-dispersed nomadic Turanians. ${ }^{203}$ Yet he utilized the comparative etymological method of focusing on the names of Turanian deities and tracing them back to their sources. In the Aryan case, Müller had found that deities playing a chief role in mythical narratives like Zeus in Greek, Jupiter in Latin, Dyaus in Sanskrit, and Tyr (Tiew) in Norse were all descended from a common root "div," meaning the sky. In a similar manner, he considered the Finnish god Jumala, the Samoïedic Num, the Turkic and Mongolic Tengri, and the Tungusic deity Buga. Many of these Turanian names for gods had also etymologically originated from natural phenomena like the sky or thunder. ${ }^{204}$ This led Müller to argue for a naturalistic interpretation of Turanian myths. He saw the Turanians still remaining in the mythopoeic stratum or being replaced by more powerful religions from outside.

\footnotetext{
201 Müller, Science of Language, vol.2, 460-61.

202 Müller, Science of Language, vol.2, 440-442.

${ }^{203}$ Müller, Science of Religion, 130.

${ }^{204}$ Müller, Science of Religion, 131-133.
} 
This perspective that Turanian cultures remained longer in the mythopoeic stratum resembles Müller's linguistic view that agglutinating languages were a more primitive stratum. Nevertheless, in coming up with laws of mythological outgrowth, he saw more or less the same phenomena occurring in both Aryan and Turanian cultures. They all began with people wondering about natural phenomena and metaphorically talking about them as though there were human agents behind natural objects. The agents gradually solidified into multiple deities, which formed the chief characters of myths. In a later text in 1897, Müller gave a vivid picture of Finnish and Mordvinian deities in their myths, with numerous celestial, aquatic, terrestrial, ancestral, and sub-terrestrial spirits. ${ }^{205}$ These spirits reflected their natural origins in the names for heavenly bodies or earthly things like forests, mountains, and rivers. The Finns had the concept of haltias, which were spirits or "geniuses" that people assigned to every general concept. ${ }^{206}$ Many general ideas like "river" and "stone" had their geniuses, which people thought of as the conscious agents behind these phenomena. From these multiple spirits, the Finns had a tendency to isolate one universal god for worship like Jumala or Ukko. Müller saw the Turanians slowly evolving in the direction of universal progress of religions towards monotheism.

Similar to the theories of mythology, there were analogies to geological strata in Müller's model for the comparative history of religions - which he also hoped to develop into a "science" in the 1870s. His lecture series in 1870 introducing the science of religion at London's Royal Institution and his Hibbert lectures in 1878 on the origins and

\footnotetext{
205 Müller, Contributions to the Science of Mythology, vol.1 (London: Longmans, Green, \& Co.,1897), $234-285$
}

206 Müller, Contributions, vol.1, 271-273. 
growth of religions were his most substantial works in this field until his Gifford lectures in the 1890s. As one can infer from Müller's biography, religion was very contentious in this era with Darwinians, theologians, and various lay thinkers challenging each other on religious truth. In addition to these controversies, Müller was personally struggling to make sense of religion in the wake of his daughters' tragic deaths. He still never gave up his theism, but tried to liberally incorporate all religions into his scientific search for truth. In popularizing comparative religion in this contentious context, Müller faced much greater hostility than with his linguistics and mythological studies. He had to deal with theologians critical of comparing Christianity with other religions, and with atheists skeptical of any "scientific" study of issues involving mysticism and the occult. ${ }^{207} \mathrm{He}$ also had to introduce his Victorian audience to several unfamiliar religions.

Approaching the study of religions comparatively and historically, Müller intended to illuminate the origins and changes of religions over time. He assured his audience that the inclusion of other religions would not lower Christianity, but rather bring it a good name for having been tolerant to other faiths. ${ }^{208}$ Drawing on Goethe's famous words on language "He who knows one, knows none," Müller argued that the same applied to religion. One would need to go beyond just fluency in one's native language or religious liturgy to understand language or religion in the general. ${ }^{209}$ The abundance of sources on multiple religions in nineteenth-century Europe and the development of critical methods

\footnotetext{
207 Müller, Science of Religion, 4. Also consult Bosch, "Friedrich Max Müller: His Contributions to the Science of Religion," in Comparative Studies in History of Religions, eds. E. Reenberg Sands and J. P. Sorenson (Copenhagen, 1999).

208 Müller, Science of Religion, 28.

209 Müller, Science of Religion, 12-13.
} 
of textual interpretation enabled broader comparative studies. To study religions, Müller emphasized the same three stages he saw all sciences passing through — the empirical, classificatory, and theoretical phases. ${ }^{210}$ Before getting to the theoretical stage, religions had to be classified and compared to discover the underlying patterns in their changes over time. Müller used a similar linguistic grouping for religions and studied them within three major families, namely the Aryan, Semitic, and Turanian groups. He recognized the numerous yet-unclassified African, Polynesian, and American religions too.

In constructing a general historical scheme for religions, Müller began by delving into the issue of their origins. This was to be the lowermost stratum or the "seed" "buried" underneath living religions and supplying their "living sap." 211 For him, the two commonly accepted means of knowledge — sense and reason—were sufficient for religions to originate. Religions had a rational origin, and there was no need for humans to possess any mysterious or miraculous abilities to have religion. ${ }^{212}$ The only difference between ordinary sense perception and religion was that the former was focused on finite objects, while the latter came from a "perception of the infinite." 213 When our senses try to make sense of the world around us through perception, they reach a finite limit beyond which they cannot tell us what lies farther. This limit could be in relation to infinitely large phenomena like the universe or infinitely small particles within atoms. Primitive humans reached this idea of an infinite existing beyond their sensory limits, and gradually

\footnotetext{
210 Müller, Science of Religion, 16-17.

211 Müller, Origin and Growth of Religion, 52.

212 Müller, Origin and Growth of Religion, 32.

213 Müller, Origin and Growth of Religion, 32.
} 
tried to comprehend it in terms of agents behind natural events like the "thunderer," "bringer of light," and "giver of rain." 14 This was the next stratum or the mythological stage. After this era, continued reflections on the infinite yielded higher religions.

The evolution of religions from their original form occurred, for Müller, entirely through human agency, rather than through God's revelation. Müller presented the course of religions in the form of several stages based on his etymologies of divine names and key sacred concepts. In the early stages when humans contemplated the infinite, they gave it anthropomorphic names that gradually became personal beings. For instance, people might have perceived the infinite in powerful objects like the sun. It could be named "the giver of light," which later people transformed into a personal agent guiding the sun on its journey across the sky. ${ }^{215}$ In this mythological stratum, the sun acquired human attributes and had a role in narratives with other such anthropomorphized natural objects. The next stage in religious history was "henotheism" with people raising some of these natural agents into supernatural deities. The "giver of light" came to be raised from a mere luminary to a supernatural force that "creates and gives life," "protects the earth from darkness," and "punishes evil."216 This henotheistic stage was rather chaotic with no one supreme god, but multiple deities temporarily elevated to the top position and worshipped. The same sun that was sometimes eulogized as the all-powerful creator was

\footnotetext{
214 Müller, Origin and Growth of Religion, 50.

215 Müller, Origin and Growth of Religion, 266.

216 Müller, Origin and Growth of Religion, 271.
} 
at other times lowered, for instance, before the water as a "child of the waters." 217 The idea of a supreme deity emerged only in the polytheistic and monotheistic stages.

After the anarchic presence of multiple gods in henotheism, people began to develop a more rigid hierarchy of gods in the next polytheistic stratum. ${ }^{218}$ They still retained a large pantheon of gods, but had a clearly-defined supreme deity who towered above the rest. Müller treated this stage as one where people tried to better generalize about the infinite and detect the working principles behind it. The classical Indian, Greek, and Roman religions exemplified this stage with deities like Indra, Zeus, and Jupiter assuming supreme roles respectively. This was a precursor to the monotheistic stage that denied the existence of all gods other than the supreme one. This progression culminated in people recognizing "the one maker of all things" and "the lord of all creatures" in the infinite. In his Hibbert lectures of 1878, Müller idealized the monotheistic stage as the highest, but turned more towards pantheism later in the $1890 \mathrm{~s}$. He fitted atheism too into this story of progress, arguing that "honest" doubts about older doctrines were crucial for advancing religions from mythology and superstition. However, he distanced nihilistic versions of atheism (or "vulgar atheism" as he termed it) from his narrative. ${ }^{219}$ Müller relied heavily on the Rigveda's history to propose this scheme of religions.

In situating the Turanian religions in this narrative, Müller recognized that "book religions" like Buddhism, Christianity, and Islam had already made big encroachments

\footnotetext{
217 Müller, Origin and Growth of Religion, 276.

218 Müller, Origin and Growth of Religion, 298.

219 Müller, Origin and Growth of Religion, 310-315.
} 
into Turanian territories. Yet he noted how earlier native religions of the Finns, Turks, and Mongols were still continuing "partly below the surface, and, in some places still on the surface too." ${ }^{220}$ As with nomad languages without written texts, he emphasized that bookless religions like Shamanism ought to be included in a comparative science of religions. Though his fifty volumes of the Sacred Books of the East were mostly on the major book religions of the Aryans, Semites, and Chinese, he incorporated the bookless religions into his patterns of religious change. The Turanian religions occupied the lower "henotheistic" or "polytheistic" strata of Müller's hierarchy. The multiple gods of natural origin and the sometimes fluctuating order of importance of these deities in Turanian mythology led Müller to associate these religions with henotheism. ${ }^{221} \mathrm{He}$ identified rudiments of a supreme god like Jumala, Num, or Tengri in these religions, but did not see them advancing beyond the polytheistic stage. He likened these henotheistic bookless religions to the "dialectal" stage of languages predating standard languages, when numerous local gods coexisted in a culture like multiple competing dialects. ${ }^{222}$

These stages of religious growth, like those of languages, functioned similar to geological strata with different layers deposited at different time periods. The "higher" strata of polytheism and monotheism came at a later period in human history than the "primitive" henotheistic stratum. This resembled inflectional languages of settled societies occurring after prior isolating and agglutinating strata. Müller encouraged such

\footnotetext{
220 Müller, Science of Religion, 67.

221 Müller, Science of Religion, 125-144.

222 Müller, Science of Religion, 201-203.
} 
analogies among language, religion, and geology, especially as he saw religion as an aspect of human thought to which language was intimately bound together. Referring to the henotheistic Turanian and Vedic faiths, he claimed:

The parler enfantin in religion is not extinct; it never will be. Not only have some of the ancient childish religions been kept alive, as, for instance, the religion of India, which is to my mind like a half-fossilised megatherion walking about in the broad daylight of the nineteenth century; but in our own religion and in the language of the New Testament, there are many things which disclose their true meaning to those only who know what language is made of. ${ }^{223}$

The analogy between henotheistic religions and the earliest languages comes out vividly in this quote from his introductory lecture in 1870 . The metaphor of a "half-fossilised megatherion" suggests how Müller interpreted some contemporary religions of his time preserving primitive features from an earlier stratum of religions. The widely heterogeneous and rapidly changing nature of languages and dialects in the Turanian family paralleled the similarly diverse deities with no one clear supreme god. Such parallels among cultural elements like language, religion, and mythology were further important to Müller because he imagined them to be the bases of nationhood and genealogical affinity of peoples. ${ }^{224}$ It was culture from below—not political dynasties like the Romanovs, Habsburgs, or Ottomans - that created national feelings in people.

While Müller clearly imagined henotheistic religions as more primitive than monotheistic ones, he showed much sympathy and respect for the cultures of primitive peoples. This was shaped by his Christian universalist view that all humans are children of the same God, and are consequently endowed with the ability to acquire some religion

\footnotetext{
${ }^{223}$ Müller, Science of Religion, 205.

${ }^{224}$ Müller, Science of Religion, 83-90.
} 
through reason and language. Müller argued for a charitable appreciation of even religions of so-called "savages"—which included the primitive tribes of Africa, Australia, and the Americas. Though the nomadic Turanians were not part of this category, Müller's criticism of lumping all savage religions into the category of superstitious "fetishism" tells much about his approach towards primitive religions in general. He treated savage religions as complex and diverse phenomena that do not just irrationally center around magical stones, shells, or other fetishes. In fact, he often reminded his audience how many Catholics and other Christians made a fetish of icons, rosaries, and crucifixes. ${ }^{225} \mathrm{He}$ humanized the savage religions by noting some higher elements in them too:

I maintain ... that the negro is capable of higher religious ideas than the worship of stocks and stones, and that many tribes who believe in fetishes, cherish at the same time very pure, very exalted, very true sentiments of the deity. Only we must have eyes to see, eyes that can see what is perfect without dwelling too much on what is imperfect.... I feel convinced that, if we want to form a true judgment of [heathen religions], we must measure them, as we measure the Alps, by the highest point which they have reached. ${ }^{226}$

Müller reduced the distance between so-called primitive and advanced humans by stressing their shared humanity, even while maintaining a story of progress. This is an overarching theme throughout his human sciences. The Turanian people have different characteristics from their Indo-European counterparts, but participate in universal human values. The next section will consider how some of Müller's contemporaries, particularly in Hungary, responded to this idea of a Turanian identity in the late 1860s and '70s.

\footnotetext{
225 Müller, Origin and Growth of Religion, 63.

226 Müller, Origin and Growth of Religion, 108.
} 


\section{The "Ugric-Turkic Battle" in Hungarian Linguistics and Turanism (1868-80)}

While Müller continued disseminating the idea of a large Turanian family in his evolutionary theories of language, mythology, and religion, others popularized this concept in Hungary too in the late-1860s in a somewhat different vein. They marked the beginning of later Pan-Turanist nationalisms that would challenge Müller's hierarchical views of cultural progress and his inclusion of Southern Asian languages in the Turanian family. As noted in chapter 1, the Hungarians were aware of their Eastern origins for many centuries based on medieval chronicles, and there were popular beliefs that an area near the Ural mountains called Yugria was their original homeland. In the mid-nineteenth century, the theory that the Hungarians belonged to the Turanian family and were related to even Turkic and Mongolic peoples gained popularity through the writings of Arminius Vambéry (1832-1913), a noted Hungarian Turkologist. ${ }^{227}$ This theory was not totally new to Hungarians, as even many eighteenth-century Magyar intellectuals had prided on their supposed Hunnic origins. They had opposed Göttingen linguists like Gyarmathi and Sajnovics, who argued for a narrow Finno-Ugric family excluding the Turkic. As Vambéry speculated on the Turanian kinship of the Magyars, a similar conflict between the supporters and critics of this idea began in the 1870s called the "Ugric-Turkic battle."

A key initiator of this debate, Vambéry was already internationally famous for his extraordinary journey to Central Asia disguised as a Turkish dervish in 1863-64, and for his fluency in dozens of European and Near Eastern languages and dialects. He was born with a congenital lameness into a poor Jewish family in the Hungarian part of the

227 Angela Marcantonio, Pirjo Nummenaho, and Michela Salvagni, “The 'Ugric-Turkic Battle': A Critical Review," Linguistica Uralica 2 (2001): 84. 
Austrian empire, speaking Magyar as his native language. After the early death of his father, he only received minimal schooling in a Jewish elementary school and a Catholic Gymnasium in the 1840s. He self-taught himself multiple languages, acquired a romantic fascination for Turkish and other Oriental languages, and set out to Istanbul in 1857. Six years after acculturating himself into Osmanli Turkish culture and religion, he decided to go to Central Asia in a dervish disguise as some Turkmen regions were controlled by rulers and bandits who persecuted Europeans. He got away with doubts about his fair complexion, experienced firsthand the brutality of Central Asian slave trade and human trafficking, and travelled as far east as Khiva and Bukhara. ${ }^{228}$ His return to Budapest with his loyal Turkmen disciple Mollah Ishak, his visits to England, and his travel memoirs made him a celebrity across Europe. Becoming a professor at Pest, he fiercely rooted for the British side as a spy for their government in the "Great Game" against Russia.

Vambéry published prolifically after his return in 1864 on his biography, linguistics of the Turkic family, the history of Hungary and Central Asia, and contemporary political issues. Starting from an article in 1869, he argued for a close relation between Magyar and the Turkic-Tatar family of Eurasia, putting himself in line with thinkers like Castrén and Müller. ${ }^{229}$ However, unlike Müller, Vambéry did not include all possible agglutinating languages like the Taïc, Malaïc, Bhotiya, and Tamulic branches of Southern Asia into a catch-all "Turanian” category. He united merely the languages of Castrén’s "Altaic" family of Northern Asian languages in his genealogical Turanian grouping. As

\footnotetext{
228 Ármin Vambéry, Arminius Vambery: His Life and Adventures (London: T. Fischer Unwin, 1889), Ch. xxi.

229 Marcantonio et al., "The 'Ugric-Turkic Battle," 84. 
his biographers David Mandler and Jacob Landau argue, Vambéry used the possible relationship between Hungarian and Turkic languages to push forward the idea that "Easterners" were not so different from Europeans. ${ }^{230}$ In the immediate years after his Central Asian travels, he stressed the superiority of Western civilization to the brutality of the tyranny and slavery he saw in Central Asia. Yet, by the 1890s, he became more positive about Central Asian hospitality and warmth as opposed to the intolerance he observed in European Christianity towards Jews like himself. ${ }^{231}$ Vambéry slowly began a shift away from Müller's placing of the Turanians at a lower civilizational stratum.

Many later Pan-Turanist nationalists in early-twentieth-century Hungary and Ottoman Empire looked back to Vambéry for having popularized the Turanian idea in Eastern Europe. While Müller and Vambéry were both disseminating their versions of this theory in the 1860s, the latter's presence at Budapest and continued role in debates with linguists gave him greater visibility as a founding father than Müller. Vambéry was also regularly in touch with the Victorian world as a frequent visitor, as a spy for the British foreign office, and as an Anglophile and Russophobe stressing British imperialism as the means for aiding the future progress of the Near East. He had met with many British Orientalists in person, and might have been familiar with Müller as the two were once at the same conference. ${ }^{232}$ Though neither Vambéry nor Müller extensively cited

\footnotetext{
230 David Mandler, “Arminius Vámbéry, Victorian Culture, and Stoker's Dracula," in Comparative Hungarian Cultural Studies, edited by Steven Tötösy de Zepetnek and Louise O. Vasvári (West Lafayette, IN: Purdue University Press, 2015), 47-58; Jacob Landau, “Arminius Vambéry: Traveller, Scholar, Politician," Middle Eastern Studies 50 (2014): 857-869.

231 Mandler, “Arminius Vámbéry,” 52-53.

232 Friedrich Max Müller, The Life and Letters of the Right Honorable Friedrich Max Müller, edited by his wife, vol. 2 (London: Longmans, Green, \& Co., 1902), 319.
} 
each other, they were both popular figures in England from the 1860s onwards.

Vambéry's stress on the linguistic and cultural similarities of Turanian peoples-breaking rigid boundaries between the "East" and "West"-even inspired some British cultural productions like Bram Stoker's Dracula (1897). ${ }^{233}$ Stoker, who had personally known Vambéry, based some elements of Count Dracula's character like his frequent shapeshifting and the contrasts between his acquired English manners and monstrous vampiric behavior on Vambéry's own metamorphoses between European, Jewish, and Turkish identities, and his many other roles as a Sunni dervish, professor, spy, and journalist.

The 1869 article Vambéry published in support of the relationship between Hungarian and Turkic languages began the "Ugric-Turkic Battle" in Hungarian linguistics. It generated opposition from linguists favoring the Finno-Ugric theory, who argued that Hungarian was more closely related to the Finnic family than to the Altaic Turkic, Mongolic, and Tungusic families. The chief linguists on the Finno-Ugric side were Josef Budenz and Pál Hunfalvy, who were both members of the Hungarian Academy of the Sciences. Budenz was originally Prussian, but settled in Hungary and studied the Uralic and Altaic languages under Pál Hunfalvy. The latter was born in Hungary of German parentage, and also promoted the Finno-Ugric theory in opposition to Vambéry. According to Budenz and Hunfalvy, Hungarian was closest to the Ugric Ostiak and Vogul languages of the Urals, and the Finnic languages like Finnish, Estonian, Lapp, and Permic. This resembles the scientifically-accepted consensus of many twentyfirst century linguists. Yet, historians like Angela Marcantonio have argued that 
nineteenth-century Finno-Ugrists were in many ways similar to the Turanists they opposed. ${ }^{234}$ Though they might have differed on whether Hungarian was closer to Finnish or Turkish, they shared a common ground that all these Uralic and Altaic languages were ultimately part of one grand family. This theory was so prevalent that Müller himself would reduce his bigger catch-all Turanian family in the 1890s to reflect the latest trends.

In addition to the Hungarian debates on the Turanian identity, Müller faced more direct attacks on his theory from linguists like Whitney, who was a German-educated American Sanskrit philologist from Massachusetts. As an exceptional student who had mastered Sanskrit and other Oriental languages by his mid-twenties, Whitney was a professor of linguistics at Yale College and a leading member of the American Oriental Society from the mid-1850s. He was a pioneering figure in linguistics in the United States, which was far behind Europe in linguistic and Oriental studies in the nineteenth century. Though Müller was his counterpart in England, Whitney’s initially-cordial relationship with him turned into a bitter feud from the early-1870s until Whitney's death in 1894. ${ }^{235}$ Their mutual hostility began with their critiques of each others' dictionary and translation works, and continued into the Darwinian debates, with Whitney taking Darwin's side against Müller. There was much personal enmity in their disputes, but Whitney also made substantive critiques of Müller's linguistic theories, including the latter's classification of languages. Yet there were some issues like Müller's stratification of languages and the geological parallel that Whitney did not explicitly criticize.

\footnotetext{
234 Marcantonio et al., 81-94.

235 Thomas Sebeok, eds. Portraits of Linguists: A Biographical Source Book for the History of Western Linguistics, 1746-1963 (Bloomington: Indiana University Press, 1967), 420-21.
} 
Whitney's major problems with Müller's linguistics pertained to the latter's claims like the impossibility of thought without language, the importance of the "original" roots, language as the barrier between humans and animals, the autonomous processes acting to change language, and the existence of three major language families (Aryan, Semitic, and Turanian). In contrast to Müller, Whitney based his theories on a central claim that words were arbitrary conventional signs instituted by humans and acquired meaning through social communication. ${ }^{236}$ His theories on the sociological aspects of language anticipated twentieth-century synchronic linguistics after Ferdinand de Saussure, and influenced many later thinkers. For Whitney, the social institution of language enables individuals to possibly play a role in its changes, and does not require any "natural" connection between words and their objects. Thinking through images can still be possible without words, and so thought and language are not identical. ${ }^{237}$ As all signs representing thoughts are arbitrary, there is nothing special about the earliest roots of human languages. Whitney viewed language as one of the many human social institutions that together separated humans from animals, instead of being a unique "Rubicon" as in Müller's view.

Bringing in the sociological emphases of his theories, Whitney attacked Müller's conception of a Turanian language family that united all agglutinating languages together. For Whitney, this was an "unscientific" grouping of several little-known languages that Müller had classified without deep research. ${ }^{238}$ Whitney refused to accept that nomadic

\footnotetext{
236 Whitney, Max Müller and the Science of Language, 9-10, 34.

237 Whitney, 30.

238 Whitney, 49.
} 
languages had to be classified using different principles from those of Aryan and Semitic linguistics. Nomadic languages need not change beyond recognition through time while cultured languages remain stable. He pointed to numerous languages with written texts that still changed significantly over a few centuries. Given Whitney's greater stress on the social uses of language for communication, he saw a centripetal force even in nomadic languages that maintained some uniformity in them for the purposes of social discourse with other individuals. ${ }^{239}$ This made him skeptical of Müller's process of dialectical splintering operating more intensely in nomadic languages. Instead, Whitney proposed subjecting all languages to the same correspondence tests for classification into families of common descent like the Aryan and Semitic ones. ${ }^{240}$ Such critiques of Müller's catchall approach pushed Müller to rethink his large Turanian grouping by the 1890s.

Considering these developments in Hungarian linguistics and Whitney's critique of Müller, one can observe that there were several voices other than Müller's shaping the contours of the Turanian idea between the late-1850s and $1880 .{ }^{241}$ Müller's analogy between linguistic change and geological strata engendered a hierarchical representation, with inflectional languages taking a more advanced place than agglutinating Turanian

\footnotetext{
239 Whitney, 55.

240 Whitney, 48.

241 Some other contemporary perspectives on Müller's overall thoughts can be found in Abel Hovelacque, The Science of Language: Linguistics, Philology, and Etymology (London: Chapman and Hall, 1877); Ludwig Noire, Max Müller and the Philosophy of Language (London: Longmans, Green, \& Co., 1879); Andrew Lang, "Mr. Max Müller and Fetishism," Mind: quarterly Review of Psychology and Philosophy IV (1879): 453-69; Lang “Mr. Müller's Philosophy of Mythology,” Fraser's Magazine 24 (1881): 166-86; B. Bourdon, "F. Max Müller. The Science of Thought" (book review), Revue philosophique de la France et de l'Etranger, vol. 25 (1888): 95-103; A. Réville, "Max Müller, Physical Religion” (book review), Revue de l'histoire des religions, vol. 24 (1891): 102-107. Th. Achelis, Max Müller und die vergleichende Religionswissenschaft, 2 vols (Hamburg, 1893); O. Gruppe, "Review of Max Müller's Contribution to the Science of Mythology," Archiv für Religionswissenschaft, 1899, 268-280; and Lang "The Theories of Max Müller," Contemporary Review 93 (1900).
} 
languages. Though he was quite sympathetic to the more "primitive" languages and religions, the emerging pan-nationalist discourse in Hungary began to challenge Müller's evolutionary strata of human phenomena. Vambéry was similar to Müller in the 1860s in treating the "Eastern" Central Asians as barbaric and despotic, but his emphasis on a Magyar-Turkic association gradually led Vambéry to romanticize some "superior" values of Eastern Turkic cultures by the 1890s. Also, the "Ugric-Turkic battle" refocused the Turanian question on the Northern Asiatic languages instead of including all agglutinating languages like Müller did. Whitney's socio-institutional approach to languages reinforced this trend by critiquing Müller's catch-all Turanian category. By 1890, Müller no longer included Southern Asian languages in the Turanian family.

\section{Some Conclusions}

Building on the Turanian theory he developed in the early 1850s, Müller used the idea of linguistic stratification to develop his theories of language and other human sciences. The Turanian family occupied an intermediate stratum that showed some characteristics different from the inflectional Aryan and Semitic families. He tried to link these strata to obtain coherent theories about the histories of language, mythology, and religion. Müller's interest might have shifted to comparative religion in the 1870s, but he still continued using linguistic categories to understand religions. This stemmed from the close interconnections he saw between language and thought of a people, and the importance of language, mythology, and religion for national identity. The geological metaphors he often employed in his lectures and writings suggest his ambition to push for treating the new human sciences, particularly comparative mythology and religion, on par 
with the natural sciences. He also emphasized the study of earlier strata of languages and religions like the Turanian ones to better understand the long-run evolution and nature of these human phenomena. His popularization of the Turanian theory, however, brought him some critics, and also took the theory to a Hungarian audience, who began to reshape the theory in accordance with their own nationalistic interests. His American critic Whitney's stress on the social communication aspects of languages raised doubts about the "otherness" of his nomadic family. Müller's catch-all approach of including both North and South Asian languages into the Turanian category soon became outdated, and he came to revise the classification in the last decade of his life. He nevertheless retained the Northern Eurasian group of languages in the "Uralo-Altaic" category. Chapter 4 details how some of Müller's ideas like the hierarchy of languages were questioned in linguistics by the early 1900s, and how his theories influenced the rise of Pan-Turanism. 


\section{CHAPTER 4 \\ Amidst Mysticism, Subjectivity, and "Decadence": Müller, Linguistics, and the Pan-Turanian Nationalists in the Fin-de-siècle Era}

The [Turanian] languages are all similar, and ... their physical and mental make-up displays undoubted affinities. They are all noted for great physical vitality combined with unusual toughness of nerve-fibres.... The Turanians have certainly been the greatest conquerors and empire-builders that the world has ever seen.... The hoofprint of the Turanian "man on horseback" is stamped deep all over the palimpsest of history.... As for the Europeans, they have recently passed their apogee, and exhausted by the consuming fires of modern industrialism, are already entering upon their decline. It is the Turanians, with their inherent virility and steady nerves unspoiled by the wear-and-tear of western civilization, who must be the great dynamic of the future.

—Lothrop Stoddard, "Pan Turanism," 1917, p.16, 22.

The present war has once more given birth to the "Turanian Question" and has brought into prominence an ideology derived from the obsolete linguistic classification of Max Müller... To be sure, however, no sensible person can have any serious objections if the notion of "Turanian kinship" between Turks, Bulgars, and Magyars is employed as a patriotic and political slogan. But as a serious scientific fact, the idea of this "kinship" can be entertained only with the utmost reservations.

—Adam Szilagyi, “Turan” in Magyar Nyelvor, 1916, p.237-239.

In the last two decades of his life (1880-1900), Max Müller ventured deeper into theories of mysticism and natural theology and synthesized them with his earlier views on language. Müller had always been a theist interested in a personal connection between God and humans. Yet it was in his later years that he systematically idealized mystical states like spiritual oneness with the transcendent in the evolution of human thought. Such ideas were part of the zeitgeist of the Fin-de-siècle era in Europe, when there was a general cultural turn towards anti-Positivist ideas favoring the irrational and the spiritual. However, unlike other Fin-de-siècle trends like pessimism about science, modernity, and human progress, Müller grounded his theories on an avowedly empiricist and scientific 
foundation. He largely retained his earlier optimism about human progress and geological metaphors for the hierarchical ascent of languages and religions through history. This curious mixing of scientific and mystical ideas formed the broad context in which Müller put forth his late views on the Turanian family. His stress on finding meaning through mysticism (a term he used himself), particularly in his Gifford Lectures (1888-93) on comparative religion, came after many deaths in his family and his anxiety about atheism.

By this time, Müller's Turanian theory and its dependence on his morphological classification of languages into isolating, agglutinating, and inflectional groups had come under pressure from many sides. In the earlier Ugric-Turkic battle in Hungary, linguists had already discarded Müller's claim that Southern Asian languages like Taïc, Malaïc, Tamulic, and Bhotiya were also Turanian owing to their agglutination. Inferring genealogical connections based on morphological features like agglutination became suspect. Müller responded in his Gifford lectures by renouncing the idea of a big Turanian family and the very name Turanian. ${ }^{242}$ Yet he still retained the Finno-Ugric, Turkic, Mongolic, and Tungusic groups in one family, calling them "Uralo-Altaic." This was similar to Castrén's Altaic family, and was a position that Pan-Turanian nationalists in Hungary and the Ottoman Empire adopted in the 1890s. One insightful point in which Müller differed from others was his claim that language and race need not overlap. Yet even this revised theory faced push-backs in the years after Müller's death. The critiques were from Finno-Ugric theorists, who, claiming no familial tie between Hungarian and Turkish, opposed the Pan-Turanists. The Finno-Ugrists gradually won out in linguistics.

242 Müller, Natural Religion, 323-326. 
The challenges to Müller's morphological classification and the conclusions he drew from it were shaped by far-reaching changes in linguistics in the late nineteenth century. Müller's view of a historical progression from isolating to inflectional languages came from early-nineteenth-century comparativists like Bopp and Humboldt, and held ground until the 1870s. From then, a younger generation of German linguists called the Neogrammarians who drew on Positivist philosophy dominated research on languages. They rejected morphological grouping — which they related to speculative theories like Schleicher's - and empirically tried to find uniform sound laws to detect genealogies. ${ }^{243}$ The Fin-de-siècle era also left its mark on morphological classification by subtly shifting groupings in the human sciences from "classes" to "types," with the latter allowing for more subjectivity and instability. ${ }^{244}$ The linguist Joseph Greenberg argues that linguists in the 1920s borrowed the idea of grouping languages into types from personality theories in psychology. ${ }^{245}$ These typologies in the twentieth century no longer resembled Müller's morphological evolution. Edward Sapir, in his 1921 book entitled Language, attacked the focus on morphology in classification, the civilizational stress on the superiority of Aryan languages, and unilinear progression. Typology diversified to include phonology and syntax, and linguists no longer matched agglutination with genealogical ties.

Apart from linguistics, Müller made significant additions to his theories of religion in his Gifford Lectures, but continued to place the non-Aryan "Uralo-Altaic" religions in

\footnotetext{
243 Greenberg, Language Typology, 39-40.

244 Greenberg, 17.

245 Greenberg, 11-12.
} 
a lower evolutionary stratum. His religious theories in the 1870s had largely dwelt on the evolution of the concept of a single God. Given his greater focus on mysticism in the 1890s, Müller expanded his theories into the relation between God and the human soul. He posited three stages of religions named physical, anthropological, and psychological religion, with the third culminating in a mystical realization of oneness. Under "physical" religion, he put his earlier discourse on the history of the idea of "God" as the infinite agent behind natural events. He added a human analog to God under "anthropological" religion. This was about the history of the idea of the "soul" as the infinite agent producing material human phenomena like breathing. The third "psychological" stage came after humans had discovered the ideas of God and the soul, and reached its highest level in the divinity of humanity or the oneness of God and soul. ${ }^{246}$ Among historical cases, Müller saw only a few religions like Christianity, Vedanta Hinduism, and Neoplatonism reaching this ideal of oneness. He mainly flagged "Aryan"-influenced ideas like "Logos" or "the Word" in Christianity as the most advanced. In this march towards progress, the Uralo-Altaic religions formed a lower stratum where people worshipped multiple spirits. ${ }^{247}$ This was a continuation of his earlier evolutionary views. With all these changes and continuities, one avenue in which Müller's linguistic classification became influential was the emerging Pan-Turanian nationalism in Fin-desiècle Hungary and the Ottoman Empire. These pan-nationalists accepted the idea of a Uralo-Altaic language family of Eastern European and Northern Asian languages, but

\footnotetext{
246 Müller, Theosophy or Psychological Religion.

247 Müller, Contributions to the Science of Mythology, vol.1, 234-283.
} 
differed by emphasizing the greatness of the nomadic Turanians. This difference was the product of wide-ranging changes by 1900 in many human sciences beyond linguisticslike ethnology, history, literature, art history, and geography. Scholars in these fields took part in Turanism in Hungary and the Ottoman Empire with the dream of bringing all Turanian peoples of Europe and Asia under one state. This new ideology was grounded in Fin-de-siècle pessimism about the progress of the West, and longings for new inspiration from hitherto-neglected Oriental and nomadic cultures. ${ }^{248}$ The pan-nationalists were skeptical about identifying with Europe and pushed for alliances with fellow Uralo-Altaic peoples - sometimes out of racial exclusivism. There was a sense that earlier models of Aryan superiority like Müller's could be challenged, and that nomadic cultures and artforms had comparably complex features. ${ }^{249}$ Influenced by Fin-de-siècle European Orientalists like Edouard Hahn and Léon Cohen, pan-nationalists like Geza Nagy and Arminius Vambéry in Hungary and Yusuf Akçura and Ziya Gökalp in the Ottoman Empire developed positive views of the Turanians. The Turanian theory was defeated in twentieth-century linguistics, but it continues culturally even in the twenty-first century.

Bringing together these diverse and sometimes contradictory developments late in Müller's life, in linguistics, and in the emerging Pan-Turanist nationalism, one can see that they all reflected some intellectual trends of the Fin de siècle. They were not uniform transformations with everybody conforming to the same pattern, but rather varied responses to the problem of linguistic diversity in light of earlier theories. There was a

\footnotetext{
248 Kessler, “Turanism and Pan-Turanism in Hungary 1890-1945," 1-53.

249 Kessler, 5-6, 13-14.
} 
subjectivist shift in linguistics away from the threefold morphological classification, its rigid and objective ordering of languages, and its evolutionary aspects with ethnocentric biases. This was a general trend as linguistics passed into the hands of the Structuralists after the Neogrammarians. Müller did revise his Turanian theory to give up including all agglutinating languages under the same genealogical group. His separation of Southern and Southeast-Asian languages from the northern Uralo-Altaic family was a shift from his earlier theory, but he did not give up the morphological groupings and their evolutionary importance. Müller's theories thus became obsolete in the twentieth century, and the opposing Finno-Ugric theory achieved successes. Second, Müller went deeper into mystical thought during the Fin de siècle, which led him to expand his theories of religion to the "highest" stage of oneness between God and the human soul. It still left his evolutionary scheme with geology-like "strata" of religions intact—a perspective that the Pan-Turanian nationalists challenged through their critiques of Western "decadence" and romanticizations of nomadic cultures. Yet it was through the nationalists that Müller's Turanian idea stayed politically relevant in the twentieth century.

\section{Müller's Late Years and the Role of Mysticism (1880-1900)}

By the late 1870s, Müller had received the opportunity to pursue his own research and publications full time, without having teaching responsibilities at Oxford. The university administrators gave him this privilege in 1876 to redress his earlier frustrations with not receiving a Sanskrit professorship and to honor his intellectual achievements. 250 This institutional arrangement freed Müller to accept invitations to lecture at various 
institutes across Britain, and supervise the editing of The Sacred Books of the East by Oxford students. He was also able to author over a dozen volumes of books expanding on his theories of language, mythology, and religion, including some on Indian philosophy and British colonial policy in India. His major lectures in this period were his Gifford Lectures on natural theology in Glasgow from 1888-92. These lectures were funded by the Scottish lawyer Lord Adam Gifford's will, and were intended to promote a scientific study of religions without appealing to superstitions or supernatural revelations. ${ }^{251} \mathrm{In}$ these lectures, Müller went beyond his earlier Hibbert Lectures and laid out his threestage theory of religions - physical, anthropological, and psychological. After 1892, he still continued working on his biographical and scholarly texts until his death.

Müller had always held a Protestant and somewhat Pietist worldview from his childhood in Dessau. This background informed his lifelong emphases on a personal connection with God, God as the universal father, restraint from excesses, skepticism of formal rituals and church dogmas, and sense of duty and order. In linguistics, his religious views made him see humans as the only creations of God who can use language and can thereby share an essential feature of God's divinity—the ability to think. While Müller's liberal Christianity was always a factor in his thought, the rise of Darwinism in the 1860s and the increasing spread of religious doubt deeply unsettled Müller and pushed him to think more about the intellectual foundations and evolution of religions..$^{252}$ Müller did not take the conservative theologians' position of defending the Bible as an

\footnotetext{
251 Adam Gifford, "Extracts from the Trust Disposition and Settlements of the late Lord Adam Gifford," in Müller, Natural Religion, xxiv-xxix.

252 Bosch, 103.
} 
infallible divinely-revealed text. Instead, he delved into the comparative study of world religions, and argued for a scientific and historical understanding of all religions in order to defend religion from atheism. In addition to the Darwinian conflicts, Müller saw the tragic deaths of his two eldest daughters Ada and Mary in 1876 and 1886. Amidst these difficulties, he hoped to derive a universal religion from his comparative studies.

The increasing attention Müller gave to comparative religion led him deeper into mystical philosophy in the 1880s and '90s. He was familiar with medieval German mystics like Meister Eckhart and Johannes Tauler, who had idealized a close personal relationship between God (or the Absolute) and the human soul. In addition, his experience with the Sanskrit tradition while editing the ancient Rigvedic hymns and other Oriental sacred books inspired Müller to relate the Christian mystics to Indian schools like Vedanta. He was drawn to the monistic elements in some Vedantic sects that argued for the identity of the human soul and the Absolute Being called Brahman. ${ }^{253}$ In his later years, Müller began to value the monistic Vedantic tradition equating divinity and humanity as one of the highest religious theories, especially by the "Aryan" mind. $\mathrm{He}$ claimed that Christianity too had reached this profound idea of oneness through its "Aryan" foundations in the Greek philosophical concept of "logos." ${ }^{254} \mathrm{He}$ interpreted "logos" as speech, reason, the word of God, or the incarnation of Jesus Christ. Müller imagined all these attributes uniting the divine and the human in Christianity. For him, this was in opposition to the distancing of God from humanity in Judaism and Islam.

\footnotetext{
253 Max Müller, Three Lectures on the Vedanta Philosophy (London: Longmans, Green, \& Co., 1894). 254 Müller, Theosophy or Psychological Religion, v-xvi.
} 
This mystical ideal of oneness that Müller observed in some of the "Aryan" religions formed the standard by which he fitted other religions like Shamanism in the evolution of religious thought. Yet his mystical emphasis in his later years did not mean that he distanced himself from rationality and science. He attacked some contemporary mystics like Helena Blavatsky of the Theosophical society for their esoteric focus on hidden knowledge. ${ }^{255}$ Müller saw the idea of oneness between God and humanity as the culmination of a long process of rational inquiry that eventually pointed to the uniqueness (and perhaps God-like aspects) of humanity amidst God's diverse creations. This issue of human uniqueness in language and thought continued to be debated between Müller and the Darwinists even after Darwin's death in 1882, with the biologist George Romanes taking on the battle with Müller. In response to the Darwinists, Müller published a text in 1887 entitled The Science of Thought in which he defended his philosophy of the interconnectedness of language and thought. Calling his theory "Nominalism," Müller stressed the importance of naming for thinking and that humans were the only beings possessing both language and reason. ${ }^{256}$ Müller's confidence that the natural selection theory failed to explain the origin of human language underpinned his mysticism.

Contemporary reactions to Müller's idealization of the mystics in his Gifford lecture series were not always positive, with harsh objections from conservatives. Some were suspicious that Müller was promoting a pantheistic idea of oneness between God

\footnotetext{
255 Bosch, 160.

256 Max Müller, The Science of Thought (London: Longmans, Green, \& Co. 1887), vii-xiv. 
and humans with a hidden motive of atheism. ${ }^{257}$ The Catholic bishop of Glasgow notoriously called Müller's Gifford Lectures “nothing less than a crusade against Divine revelation, against Jesus Christ, and against Christianity." 258 The bishop attacked Müller's tendency to treat miracles as superstitions, to narrow the chasm between God and sinful humanity, to repudiate papal and church dogmas, and to foreground unaided reason in the search for truth. Müller, however, had not intended to discredit Christianity. He had adhered to the Gifford lectures' norms to discuss religions scientifically. The attacks from conservatives did not harm Müller's reputation as he continued to receive awards from royalty, research academies, and universities. His supervision of the Sacred Books of the East and his vast publications won him a place in Queen Victoria's Privy Council in 1896 and an order of merit from the Ottoman Sultan Abdul Hamid II. Müller received the latter while visiting Istanbul to see his son Wilhelm, who worked there as a diplomat then.

Considering Müller's broader concerns during the Fin de siècle, the Uralo-Altaic (or Turanian) languages and religions were only peripheral to his thought. Apart from his scholarly works, he focused his political involvements in this period on nationalities speaking Indo-European languages. His fascination with the Aryan family reflected both his scholarly experience with these languages and his admiration for their cultures. Though a naturalized citizen of Britain from the 1850s, Müller held a dual loyalty to both Germany and England. ${ }^{259}$ This was apparent in the Franco-Prussian War during which he

\footnotetext{
257 Bosch, 152.

258 Chaudhuri, Scholar Extraordinary, 362.

259 Bosch, 100-101.
} 
tried to justify the German cause, and bring England and Germany on the same side by mediating between William Gladstone and Otto von Bismarck. Also, during the Boer War in 1899, Müller wrote articles in the German press supporting the English side. ${ }^{260}$ However, his diplomatic efforts failed to unite Britain and Germany given the imperial rivalries of the time. Müller also sympathized with India given its Aryan civilization, and, in lectures like India: What can it teach us? (1882), advised British officers to be more respectful towards the Indian people. ${ }^{261}$ Staying in touch with Indian religious reformers and mystics, he encouraged dialogues between religions of the East and West.

The focus on a mystical oneness and somewhat universalist principles continued in Müller's thought until his death in October 1900. The last decade of his life had brought him some good news, with his third daughter Beatrice giving birth to several grandchildren. Müller's death brought together his family, friends, representatives of European royalty, and condolences from foreign countries like India. The large number of positive appraisals of his life soon after his death testified to his fame during his living years. ${ }^{262}$ However, his works were no longer so widely read after his death. As the Fin de siècle pulled down the curtain on evolutionary historical approaches to the human sciences, new intellectual trends like Structuralism and socio-psychological perspectives pushed Müller's theories into obscurity. His wife Georgina and son tried publishing some of Müller's edited letters, memoirs, and selected quotations posthumously, but they failed

\footnotetext{
260 Bosch, 170-171.

261 Max Müller, India: What Can It Teach Us? (New York: John W. Lovell Co., 1883).

262 Bosch, 480-491.
} 
to keep up Müller's influence in Europe. ${ }^{263} \mathrm{He}$ was left to be read only by scholars of religious studies and Sanskrit literature, and by Indian nationalists who found him critical of racist imperial attitudes. The Pan-Turanist nationalists too found some support in Müller's classification scheme, and it is this issue that the following sections will address.

\section{Fin-de-siècle Linguistics and the Turanian Language Family}

Just when Müller was delving into theories of mysticism and religion, a new generation of German linguists began to diverge from the earlier comparative-historical tradition of Bopp, Humboldt, and Müller. From the mid-1870s, younger linguists called the Neogrammarians (Junggrammatiker) applied a strict Positivist approach to studying languages that questioned speculative aspects of earlier theories. Envisioning historical linguistics as an empirical science, they rejected Schleicher's speculative analogies relating languages to biological organisms that grow, mature, and decay. Müller too had speculated about decay in his theory of mythology as a linguistic disease. Instead, the Neogrammarians explained historical changes in languages in terms of regular sound shifts they assumed to be pervasive. Following leaders like Karl Brugmann and Hermann Osthoff, they saw changes in words over time as not random, but as driven by uniform laws operating by "blind necessity." ${ }^{264}$ They also shifted linguistic practice from studying historical languages in books to modern living dialects—like Castrén's fieldwork. This was different from Müller's focus on dead languages, though he too had recognized that

\footnotetext{
263 Bosch, 497. Müller's wife Georgina and son Wilhelm helped posthumously publish an incomplete autobiography of Müller (My Autobiography: A Fragment), a volume containing his life and letters (The Life and Letters of the Right Honorable Friedrich Max Müller), and Last Essays: Essays on the Science of Religion (London: Longmans, Green, \& Co., 1901).

${ }^{264}$ Robins, A Short History of Linguistics, 210.
} 
dialects mattered in language change. Based on dialect studies, the new linguists came up with rules like Verner's Law that explained even exceptions to Grimm's Law.

The Neogrammarians brought in new emphases to linguistics, but they continued with a primarily historical orientation as their earlier counterparts. The Fin de siècle saw subjectivist challenges to the Positivism of Neogrammarian linguistics, with the rise of an Idealist school led by Karl Vossler. The Idealists questioned the uniform impact that the Neogrammarians assumed sound changes to have on all words in a language. Instead, Vossler paid attention to how an individual can shape language through his/her creativity and diffuse changes through a society. Ironically, dialectological studies inspired by Neogrammarian thought gradually undermined their own thesis of uniform sound changes owing to the fluidity of dialect boundaries and the randomness of inter-dialectal exchange. ${ }^{265}$ The subjectivist turn went against some of Müller's theories too, as he had also drawn on rigid laws resembling the natural sciences to explain the progression of languages from the isolating to inflectional stages. Later, the early twentieth century saw the Structuralist breakthrough in linguistics after Ferdinand de Saussure. This finally ended the nineteenth-century historical emphasis, and began to treat each language as a synchronic system with all grammatical elements defined in relation to each other.

These larger shifts in linguistic thought impacted the theory of a Turanian family of agglutinating languages and its association with the threefold morphological classes. The Neogrammarians focused on scientifically establishing the genealogical classification of languages based on systematic sound shifts over time, and they did not find the 
differences in morphological structures of languages helpful in this regard. ${ }^{266}$ Some languages might have words composed of only independent roots, while others might have words that fuse their roots and affixes to varying degrees. The Neogrammarians, unlike the earlier comparative-historical linguists such as Müller, found little match between their sound laws and the supposed progression of languages from isolating to inflectional morphologies. They associated the latter with Schleicher's idea of a Hegelian Sprachgefühl leading languages to progress, which was "unscientific" metaphysics in the Neogrammarian worldview. Moreover, these new linguists repudiated the classification of languages as wholes, and instead turned to particular properties of languages - which was an important shift as any language could have a mixture of isolating, agglutinating, and inflecting words. ${ }^{267}$ These trends firmly divorced morphology from genealogy.

While the Neogrammarians did not extend much significance to the agglutinating property shared by many so-called Turanian languages, other changes in linguistics during the Fin de siècle further challenged the morphological classification. The subjectivist shift in many human sciences during this era affected linguistics too-as showcased by Vossler's Idealist school. The German philosopher Wilhelm Dilthey's theories in the 1880s separated the human sciences' focus on understanding individual events from the natural sciences framing general laws. ${ }^{268}$ This diverged from Müller's alignment of linguistics with natural sciences like geology in the 1860s and 70s. The

\footnotetext{
266 Greenberg, Language Typology, 39.

267 Greenberg, 40.

268 Greenberg, 16.
} 
greater emphasis on subjectivity in human sciences like linguistics led to a gradual conceptual shift from "classes" of languages to "types," with the latter connoting a less rigid ordering. Instead of pigeon-holing all languages into mutually-exclusive classes as in the natural sciences, the new "typologies" of languages were intended to bring an empathetic Verstehen to studying the patterns of linguistic diversity. ${ }^{269}$ The linguist Joseph Greenberg attributes the shift from "classification" to "typology" in the 1920s to linguists borrowing the latter term from personality theories in psychology. ${ }^{270}$ Types of personalities like extroverts and introverts formed a model for types of languages.

The shift towards typologies of languages became prominent in the Structuralist paradigm of linguistics in the early twentieth century. Its focus on each language as a unique self-contained system of interrelated elements made typologies conducive to express the differences between languages. Yet, like the Neogrammarians, the Structuralists did not accept the centrality of the threefold morphological types in linguistics. Morphology became only one of many parameters of grouping languages, and categories like syntactic word order, number of phonemes and syllables, and types of historical changes acquired importance. The external features of words were no longer so obviously key factors in the historical evolution of languages. Structuralists like Edward Sapir critiqued the earlier tendency to treat some inflectional Aryan languages as superior to isolating and agglutinating languages. ${ }^{271}$ In his 1921 text Language, Sapir also attacked

\footnotetext{
269 Greenberg, 17.

270 Greenberg, 11-12.

271 Greenberg, 41.
} 
the nineteenth-century evolutionary view of isolating languages transforming themselves into agglutinating and inflectional languages in a unilinear way. Sapir was influenced by the anthropologist Franz Boas' critique of evolutionary theories that idealized European civilization. These changes ended the dominance of morphological classes in linguistics.

As these changes were underway in linguistics during the Fin de siècle, Müller had to navigate through a field that had passed him by since his famous lectures in the $1860 \mathrm{~s}$. His Turanian theory that argued for a family of agglutinating languages of Europe and Asia had faced criticisms in the Ugric-Turkic debates in Hungarian linguistics (from 1869 onwards). In those debates, the contention was over whether Hungarian was closer to Finnish or Turkish in the supposed Uralo-Altaic family of Northern Asian languages. These linguists like Vambéry, Hunfalvy, and Budenz did not continue including the agglutinating languages of Southern Asia like Taïc, Tamulic, Bhotiya, and Malaïc in the same family. Other critics like Whitney had argued against Müller's inclusion of vastly different languages in the Turanian family citing rapid changes in nomadic languages. Whitney countered that the need for social communication could hold even preliterate languages together from changing too unrecognizably. ${ }^{272}$ Besides theoretical critiques, there was much richer data on Asian languages by the 1890s owing to the expansion of the British Empire. The diversity of these languages became apparent in ways that Müller had not foreseen in the 1850s. This led him to revise his older classification of languages.

In his new classification of languages he presented as part of the Gifford lectures, Müller included merely the Finno-Ugric, Turkic, Mongolic, Samoïedic, and Tungusic 
languages of Europe and Northern Asia in a family he called "Uralo-Altaic."273 This did not contain the Southern Asian Taïc, Malaïc, Bhotiya, and Tamulic languages. Reflecting on these changes from his former essay on the Turanian family, Müller said defensively:

Another disadvantage from which the aged scholar suffers is that he is blamed for not having known in his youth what has been discovered in his old age.... Considering the rapid advance of linguistic studies, a great part of that letter [on the Turanian languages] became antiquated long ago.... I could not possibly have known in 1854 what has been discovered since as to a number of these Turanian languages, [but] everybody who writes on any of them seems to be most anxious to show that in 1894 he knows more than I did in 1854. No astronomer is blamed for not having known the planet Neptune before its discovery in 1846, or for having been wrong in accounting for the irregularities of Saturn. But let that pass, I only share the fate of others who have lived too long. ${ }^{274}$

Müller cited recent advances in linguistic data as the primary reason for modifying his theory. The Northern and Southern languages of Asia were simply too heterogeneous to be grouped together. In his Gifford lectures, Müller admitted that similar agglutinating morphology was no longer a sufficient condition to constitute a genealogical family. ${ }^{275}$ He was aware of the decline of morphological classes in Neogrammarian and Fin-desiècle linguistics. Still, he refused to abandon the evolutionary narrative from isolating to inflectional languages, and continued to put the Uralo-Altaic dialects in the middle agglutinating stratum that might eventually transform into the inflectional stage. ${ }^{276}$ Müller's revision differed from the latest trends of his time by retaining such older ideas.

\footnotetext{
273 Müller, Natural Religion, 323-326.

${ }^{274}$ Max Müller, My Autobiography: A Fragment (New York: Charles Scribner’s Sons, 1901), 159-160.

275 Müller, Natural Religion, 321.

276 Müller, Natural Religion, 321.
} 
Another aspect in which Müller's new classification differed from his earlier one was that it reflected contemporary advances in understanding other non-Aryan and nonSemitic languages of the world beyond Eurasia. By the 1890s, Müller no longer engaged in cutting-edge research on classifying languages, and his work was mostly derived from those of other experts in linguists. His interests became centered on religion and mysticism, though he held that studying languages was a key stepping-stone to learning about a people's beliefs and customs. ${ }^{277}$ In this respect, his new classification touched on the languages of Africa, America, and Oceania. In the 1850s, there was not enough information on these languages, and Müller had speculated that the Turanian languages could be related to all of them. This was from his concern to establish the monogenesis of all languages. But by the Fin de siècle, non-Eurasian languages had been sorted into different families that had little connection to the Uralo-Altaic family. In Müller's updated list, there were African language families like Bantu, Hottentot, Western Negro, and Hamitic; American families of Mexico, Peru, Brazil, and Central and North America; and Oceanic families like Melanesian, Micronesian, and Polynesian. ${ }^{278} \mathrm{He}$ admitted that this list was tentative, but treated these families independently from the Turanian group.

In this new classification, Müller's Uralo-Altaic family resembled Castrén's old category of "Altaic" languages that included the Finno-Ugric, Samoïedic, Turkic, Mongolic, and Tungusic branches. As noted in Chapter 2, a key difference from Castrén was that Müller treated this genealogical grouping as purely linguistic and not racial.

\footnotetext{
277 Müller, Natural Religion, 280-281.

278 Müller, Natural Religion, 340-350.
} 
Castrén had conflated these two categories in his publications in the 1840s and '50s. However, Müller continued his own arguments from the 1850s that languages could be transferred to people of different races through conquests and cultural intermixing. He implied that all speakers of a language family need not be of the same racial stock. This was an insightful idea that later Pan-Turanian nationalists often ignored by confusedly superimposing race, language, nation, tradition, and religion on each other. Müller was critical of such nationalists on the Aryan side in his 1888 book on the Aryan "homeland." ${ }^{279} \mathrm{He}$ attacked the theory of Scandinavian origin of the Aryans, which saw the Nordic element as the core Aryan identity and relegated Persian and Sanskrit speakers to degenerate descendants. This theory mixed the Nordic racial element with IndoEuropean language speakers and often attempted to draw support for various European nationalisms. Müller disentangled these concepts of race and language, and claimed an Asiatic origin of Aryan languages and their subsequent spread across many races. ${ }^{280}$

Taken together, Müller's revised theory of the Uralo-Altaic family mixed some of his own older ideas with others that reflected the changes going on in linguistics at the time. The centrality of morphological classes in the nineteenth-century in describing the historical evolution of languages was fading away owing to the Neogrammarians, the Idealists, and the twentieth-century Structuralists. The subjective turn during the Fin de siècle played a role in the shift from rigid morphological "classes" to multiple linguistic parameters called "types." Müller gave up including all agglutinating languages in the

\footnotetext{
279 Max Müller, Biographies of Words and the Home of the Aryas (London: Longmans, Green, \& Co., 1888), 80-127.
} 
same genealogical category, and thereby acknowledged a partly lesser role for morphological similarity. Two languages alike in agglutination could have reached that stage from very different earlier conditions - not necessarily from common descent. He also limited the scope of his classification merely to languages — not to races. Yet, despite the changes in linguistics, he held on to the evolutionary trajectory of languages from isolating to inflectional groups. Overall, Müller's idea of a Uralo-Altaic family—which many Pan-Turanists interchangeably used with the term "Turanian"- - resonated with some Hungarian and Turkish nationalists in the Fin de siècle. Before examining this legacy, the next section considers how Müller presented the Uralo-Altaic religions in relation to his broader mystical theories in the Gifford Lectures on natural theology.

\section{The Many and The One in Müller's Natural Theology}

Müller's retention of morphological evolution from the isolating to inflectional strata was also reflected in his theories of comparative religion during the Fin de siècle. He continued to invoke the geological strata metaphor to hierarchically organize the course of religious history, with some forms of "Aryan" mysticism constituting the most advanced strata. While he was more respectful than many of his Victorian peers towards even "savage" religions, Müller's approach was different from the Pan-Turanist nationalists who exalted the superiority of the Turanians. He affirmed that monistic "Aryan" faiths had reached the highest "theosophy" — which he defined as the highest idea of God in the mind of man. ${ }^{281} \mathrm{He}$ gave this progress a tinge of the Protestant work ethic by noting that concepts like God and the soul were open for all, but had to be

\footnotetext{
281 Müller, Psychological Religion, xvi.
} 
"gained by the sweat of [one's] own face." ${ }^{282}$ Müller had already presented the three ascending stages of henotheism, polytheism, and monotheism in his Hibbert Lectures of 1878. In his Gifford Lectures of the early 1890s, he went further than just monotheism, and focused on the relationship between God and humans. Even with such revisions, the lower position of Uralo-Altaic religions in his evolutionary ladder did not change.

In presenting the comparative history of religions, Müller identified three stages that he labelled physical, anthropological, and psychological religion. The first two were earlier stages that might have occurred together, while the third stage formed the most advanced. The first two stages involved humans trying to understand natural phenomena and eventually arriving at the concepts of God and the soul respectively. Müller held that all humans could arrive at religious truths using reason, language, and observation of their natural surroundings. He did not accept supernatural revelation to any one chosen people, and claimed that Biblical miracles like the parting of the Red Sea, manna from heaven, and even the bodily resurrection of Christ might not have actually happened. ${ }^{283}$ Instead, humans arrived at the idea of God in the physical religion stage by rationally perceiving an infinite lying beyond finite natural events. This process began with people wondering about the agency behind the sun, moon, earth, sky, thunder, rivers, and other physical events. More primitive cultures posited an agent for every phenomenon and imagined multiple gods representing the sun, moon, and so on. Over time, people realized that none of these agents of things could have been self-created and omnipotent. This led

282 Müller, Anthropological Religion, 183.

${ }^{283}$ Müller, Anthropological Religion, vii-xx. 
more advanced cultures to believe in one self-moving mover-God. Henotheism, polytheism, and monotheism were now, for Müller, stages of physical religion. ${ }^{284}$

This progress of religions towards monotheism or physical religion was not the only significant aspect of religion in Müller's Gifford Lectures. As he was then immersed deeper in mystical thought than before, he also focused on the history of the idea of the soul — parallel to that of God. This narrative became his anthropological religion, which was the human search for an "infinite in man" (the soul) similar to the "infinite in nature" (God). Just as primitive humans pondered on the agency behind physical events, Müller insisted that they were curious about the agency behind human life too. In the earliest stages, they saw life caused by material agents like the blood, beating of the heart, liver, and breath. Gradually, humans came to realize that these material agents of life were not themselves eternal, and began to believe in an immaterial and eternal entity they called the soul. ${ }^{285}$ Similar to God being considered as the ultimate agency behind the natural world, the soul came to be treated as the infinite agent behind life. Müller based his claims on the etymologies of words for the soul in many languages, which often pointed to material roots referring to the blood, heart, or breath. ${ }^{286}$ From here, he argued, most advanced religions went on to reach concepts like ancestral spirits and souls.

Müller's history of religions in their physical and anthropological stages suggested a gradual evolution from believing in multiple spirits of nature and ancestors to realizing

\footnotetext{
284 Müller, Anthropological Religion, 75-76. Also consult Max Müller, Physical Religion (London: Longmans, Green, \& Co., 1891).

285 Müller, Anthropological Religion, 195.

286 Müller, Anthropological Religion, 196-206.
} 
the existence of one God and soul. Once a culture had arrived at these two concepts, it could advance to the highest stage - psychological religion. This involved relating the two infinites of God and soul to each other, and arriving at the conclusion that it is logically impossible to have two infinites that imply mutual limits. ${ }^{287} \mathrm{~A}$ belief in the infinite, therefore, would culminate in one infinite encompassing all that exists, which Müller interpreted as the oneness uniting God and the human soul. This mystical belief meant that there were some identical attributes shared by both the divine and the human, like reason, thought, and language. He recognized that there were religions that had already achieved this mystical sense of oneness of everything. The ancient Greek Eleatics, Neoplatonists, and the Vedanta school of Indian philosophy united God and humans into one universal self. In his later years, Müller showed deep admiration for such philosophies that saw divinity in humanity. He pointed out that the Aryan traditions of the Greeks, Romans, and Indians were among the first to reach this highest stage. ${ }^{288}$ In positing this hierarchy of religions, Müller included Christianity in the most advanced psychological stage and credited it to the "Aryan" influence on it through ancient Greek Stoic philosophy. For him, Semitic religions like Judaism and Islam had created a gulf between God and the human soul by stressing the authority of God's will. ${ }^{289}$ Christianity formed an exception to this through the concept of "logos" borrowed from Stoic thought by early church fathers like St. Clement and Origen. The Stoics had

\footnotetext{
287 Müller, Psychological Religion, 93.

288 Müller, Psychological Religion, x.

289 Müller, Psychological Religion, ix.
} 
used the term logos to represent the order or natural law in the universe, to which humans should ideally attempt to conform. The early Christians understood logos as the thought or speech (the "Word") of God. This came from the Platonic view of seeing the world of ideas as the perfect one over the phenomenal world. ${ }^{290}$ Such perfect ideas became for Christians thoughts in the mind of God, which God uttered as the Divine Word. As they supposed God to have created his only-begotten world by speaking, the Christians associated God's Word with his only-begotten son Jesus Christ. Through the Word's incarnation in human form as Christ, humans and God became linked with the possibility of humans attaining oneness with God—as espoused by Christian mystics like Eckhart. ${ }^{291}$ In this way, the "Aryan" idea of logos led Christianity to the highest mysticism.

Placing the mystical side of Aryan-influenced religions at the highest level, Müller continued his earlier approach of seeing the Uralo-Altaic religions occupying a more primitive stratum. He included the latter in the early physical and anthropological strata of religions, where people were working towards the higher ideas of God and the soul. He focused on pre-Christian Uralic religions of the Finns and Mordvinians, and noted their numerous gods and spirits connected to nature. ${ }^{292}$ The Mordvinians, for instance, had a chief deity called Chkaï, who represented the sun and headed a realm of gods and goddesses of nature. The local myths claimed that the wife, sons, and daughters of Chkai controlled various aspects like the earth, sky, light, darkness, fire, agriculture, fruits,

\footnotetext{
290 Müller, Psychological Religion, 518.

291 Müller, Psychological Religion, 506-526.

292 Müller, Contributions, vol. 1, 234-285.
} 
animals, and bees. These were key concerns for pastoral and agrarian people, and they worshipped their gods to protect and better their lives. They had ideas of ancestral human spirits going to an underworld similar to the Greek Hades. Müller also found incipient metaphysical stories about the creation of the world and of humans by Chkai and his evil antithesis Chaitan. ${ }^{293}$ Such myths showed, for him, how religions slowly tried to grasp more abstract concepts of God and the soul by pondering over nature. He noted similar natural bases behind the Finnish god Jumala (thunder) and Mongolic Tengri (sky).

Müller thus fitted the Uralo-Altaic religions into his evolutionary narrative that celebrated "Aryan" mystical traditions as the highest psychological stage of religion. His ideas resembled the evolutionary theories in contemporary books like Edward B. Tylor's Primitive Culture (1871) and James Frazer's The Golden Bough (1890). These authors had also posited stages of myths and religions, but had been dismissive of religions as primitive errors of pre-scientific societies. In contrast, Müller—owing to his optimism about uniting science and religion-idealized the mystical idea of oneness as the culmination of religious progress. His own religious outlook gave Müller a touch of sympathy towards other religious traditions, as he saw all religions containing some truth. He tried to find commonalities in the histories of various religions to defend his faith from atheism. This was a central motive behind his grand project of collecting and editing Oriental sacred books. The pre-Christian and pre-Islamic religions of the Finnic and Turkic peoples did not produce systematic treatises except for a few prayers, incantations, and proverbs. Yet he imagined them following a similar path of evolution as the so-called

\footnotetext{
293 Müller, Contributions, vol. 1, 248-255.
} 
advanced faiths, albeit at a different pace. His optimistic narrative even during the Fin de siècle was not, however, shared by all. The next section details how the rise of the PanTuranists in Fin-de-siècle Hungary and Ottoman Empire inverted this triumphant view of Aryan progress, projecting a new world historical role for the Turanians.

\section{In Search of Turan: The Pan-Turanists and Fin-de-siècle Thought}

A new outlook towards the non-Aryan and non-Semitic peoples of Eastern Europe and Northern Asia blossomed in the 1890s. Challenging the linear narratives of history that saw European civilization as the culmination of human progress, some Magyar and Turkish intellectuals projected the greatness of their own national culture alongside those of their supposedly genealogically-related Turanian or Uralo-Altaic brethren. Nationalism per se was nothing new in Hungary or the Ottoman Empire in the 1890s. However, the new Pan-Turanian nationalism that emerged in this period differed from earlier Hungarian, Pan-Ottoman, and Pan-Islamic nationalisms by its rejection of the West and by its association with Eastern peoples like the Tatars, Mongols, Manchus, and even the Japanese. The new nationalists developed a new sense of identity based on the linguistic theories of Castrén, Müller, and Vambéry about the Turanian family. Often ignoring Müller's admonitions, the pan-nationalists extended this idea of a family far beyond linguistics to claim the racial, cultural, and physiological affinity of all Turanians..$^{294}$ Some even pushed for the political unity of all Turanians scattered across Europe and Asia, and created Turanist associations that were quite influential during World War I.

\footnotetext{
294 Kessler, "Turanism and Pan-Turanism in Hungary," xxxii-xxxiii.
} 
The rise of the Pan-Turanists was the result of far-reaching intellectual and political changes in the Fin-de-siècle world. The cultural status of the Turko-Mongol nomads of Central Asia received a stunning boost owing to new archaeological finds of written Turkic inscriptions over a millennium old in the Orkhon-Yenissei region of Mongolia. 295 This discovery challenged earlier beliefs that nomadic peoples lacked literature and high culture. This occurred during the general European trend of cultural pessimism over the course of the Fin de siècle. There was cynicism about European social, political, economic, and intellectual traditions in contemporary culture. Urbanization, industrial capitalism, democracy, science, rationality, and progress were all thrown into question. In this milieu, new theories of nomadic civilizations challenged their inferiority to the Europeans. The German ethnologist Edouard Hahn argued that nomadism was actually a later stage than agriculture, and that the mounted warrior-nomads enjoyed advantages over sedentary societies in establishing large empires like the Mongol Empire. ${ }^{296}$ Likewise, the French traveller Leon Cahun's famous book Introduction à l'Histoire de l'Asie: Turcs et Mongols des Origines à 1405 (1896) influenced Pan-Turanists by its positive view of the militaristic and bold achievements of the Central Asian nomads. ${ }^{297}$

In addition to the new approach towards the nomads, several scholars in the human sciences suggested a possible shared culture of the Turanian or Uralo-Altaic peoples. Such theories emboldened Pan-Turanist nationalists to push for the political unity of

\footnotetext{
295 Kessler, 2-3.

296 Kessler, 5-6.

297 Kessler, 13-14.
} 
these vastly scattered peoples. Many of these ideas came from outside linguistics, though they matched up with the Turanian family theory. For instance, the German geographers Edward Suess and Friedrich Ratzel popularized the term "Eurasia" to bring together Eastern Europe and Northern Asia into one unique geographical unit. ${ }^{298}$ This concept challenged the centuries-old tradition of distinguishing Europe from Asia by suggesting that the continuous steppe and forest landscape set apart "Eurasia" from Western Europe and Southern Asia. As the Turanian peoples mainly inhabited "Eurasia," this geographical theory inspired the pan-nationalists by its idea of one enormous and uniform territory. Also, human sciences like anthropology, art history, and archaeology paid more attention to non-Western cultures as opposed to just focusing on classical Greece and Rome. ${ }^{299}$ The art of the Scythians and other nomads gained visibility in European academia, and opened up the question whether all Eurasian nomads shared a common culture.

Some political changes in Fin-de-siècle Europe promoted Turanism in Hungary and the Ottoman Empire as well. The Magyars were one of the two state-bearing peoples in the Dual Monarchy of the Austro-Hungarian Empire, and had several Slavic minorities like Slovaks, Poles, and Serbs living in their territory. By 1900, the Slavs increasingly asserted their own desire for sovereignty and were turning hostile to the assimilatory practice of Magyarization imposed by the Hungarian elite on other ethnicities. ${ }^{300}$ The resistance to coercion and the fear of unified Pan-Slavist aggression pushed many in the

\footnotetext{
298 Kessler, 6-7.

299 Kessler, 17-18.

300 Kessler, $\mathrm{xxxx}-\mathrm{li}$.
} 
Hungarian nobility to consider alternative allies abroad. The Turanian theory gave such Hungarians the hope of allying with their genealogically-related peoples to combat the Slavs. These tensions coincided with new alliances in European politics that put Britain and France on the same side as Russia, and Germany and Austro-Hungary on the other. With Russia on the opposite side and its support for Slavs, many Hungarians felt insecure about their lack of ethnic allies in Europe and sought for a solution through Turanism. Also, Social Darwinist ideas treating states with the largest territories as the fittest were popular during the Fin de siècle, and motivated the Hungarians to seek their Lebensraum in the East. ${ }^{301}$ Likewise, the Ottoman Turks too tried to connect with their Eastern brethren after heavy territorial losses in Europe and tensions with their Arab minorities.

Both the political tensions and the more positive approach towards the Eurasian nomads led some intellectuals in Hungary to conceive of a Pan-Turanist union. ${ }^{302}$ Müller was never a Pan-Turanist nationalist, but his theories became useful for the latter. An early Pan-Turanist in the "Ugric-Turkic battle" was the famous traveller and diplomat Vambéry (see chapter 3), who argued that the Magyar language was closely related to the Turkic branch and was a member of the Uralo-Altaic family. By the 1890s, other Hungarians like Geza Nagy, Lajos Sassi-Nagy, Gyula Meszaros, Bela Posta, Zsolt Beothy, Sandor Marki, and Arpad Zempleni—mostly from the lower nobility—added their voices as pan-nationalists. They were from diverse fields like museum curating, ethnography, archaeology, philosophy, history, and poetry. They no longer relied on

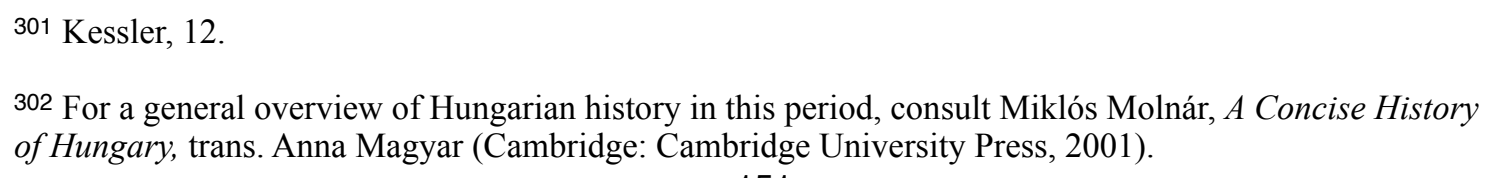


purely linguistic evidence to support the idea of a Turanian family. ${ }^{303}$ Institutions like the Magyar Ethnographic Society, which were set up to research the origins of the Magyars, became a stronghold of Pan-Turanists. Some were visionaries who popularized the idea of liberating all Turanians from imperialism and achieving a unified Turan, while others led research expeditions to the East or focused on organization-building in Budapest.

Around the same decade, a similar pan-nationalism emerged in the Ottoman Empire and among Turks living under Imperial Russia. Here, Pan-Turanism often got confused with Pan-Turkism, with the latter meant exclusively for the Turks instead of all Uralo-Altaic peoples. ${ }^{304}$ However, there were many thinkers like the émigré Russian Tatar Yusuf Akçura who also made connections with the Hungarians as fellow-Turanians. The earliest Turks to express Pan-Turanist ideas were Russian Tatars living in Crimea, Kazan, and Baku, especially because such Turks lived under foreign imperialism and hoped for self-determination for all Turks. The relatively-liberalized Russian politics after the reforms in 1905 opened up opportunities for Pan-Turkists to publish their writings and form associations. ${ }^{305}$ Yet, with the 1908 Young Turk Revolution in the Ottoman Empire, the new regime there was more favorable towards this pan-idea than the earlier Sultan Abdul Hamid II. ${ }^{306}$ These changes led many Russian Tatars to emigrate to the Ottoman Empire and collaborate with the locals in founding Pan-Turkist organizations.

\footnotetext{
303 Kessler, 70.

304 Landau, Pan-Turkism, 1, 30.

305 Landau, Pan-Turkism, 11

306 Landau, Pan-Turkism, 46.
} 
Alongside the political scientist Akçura, the educator Ismail Gasprinsky, the poet Mehmet Emin Yurdakul, and the sociologist Ziya Gökalp were influential Pan-Turkists.

This pan-nationalistic vision was mostly a romantic idealism of a few hundred elite intellectuals, but it also had political impacts especially at its peak during World War I. The Hungarian side established a Pan-Turanist organization named the Magyar Turanian Society in 1910 to take practical steps to achieve the idealistic goals. This society attempted to build cordial relations with the Turks and other Turanians by welcoming the latter's visits to Hungary, and by establishing student programs for Turkish youth in key technical disciplines. ${ }^{307}$ It hoped to use propaganda to educate people at home and abroad about the Turanian ideal. The society also planned for a museum and library in Budapest to highlight the Eastern heritage of the Magyar nation and its Eurasian relatives. These actions got the Hungarian government's attention during World War I as Austro-Hungary and the Ottoman Empire were fighting on the same side as the Central Powers. ${ }^{308}$ As the Pan-Turanist ideology was helpful to strengthen the wartime alliance, the government offered the pan-nationalists offices in the parliament building. Such high hopes crashed after the Hungarians' defeat in the war and their massive territorial losses owing to the Trianon Treaty. The Pan-Turanists were never entirely wiped out, but their plans for a vast Turanian nation could not recover the popularity they had during World War I.

In the late Ottoman Empire, the Pan-Turanist surge influenced some leading political players in the Young Turk administration like Enver Pasha. The pan-nationalism

\footnotetext{
307 Kessler, 145-148.

308 Kessler, 138-139.
} 
was partly culpable in some notorious events in the Ottoman Empire during World War I. The regime tended to emphasize the Turkish national identity more than its predecessor, which often alienated many non-Turks in the empire. While the Young Turks also continued appealing to other shared identities like Islam and Ottoman citizenship, leaders like Enver occasionally tried to use their power to achieve a large Turanist union. ${ }^{309}$ The forcible removal of Armenians from their homes and their genocide was partly because of Enver's desire to have territorial continuity between Anatolian Turks and their fellowTuranian Azeris. ${ }^{310}$ Even after defeat in World War I, Enver shifted base to Central Asia and led a Turkic rebellion for freedom from the Bolsheviks until the Red Army shot him dead. Not all Pan-Turanists, however, wished their ideology to promote violent racial hatred. Gasprinsky, for instance, was an educator for whom Turanist self-assertion was a way to achieve equal partnership in the Russian Empire with the Slavs. Nevertheless, as in Hungary, Turanism declined in Turkey during Mustafa Kemal's rule because of his focus on local Anatolian nationalism after the long War of Independence.

Pan-Turanist nationalism was in many ways rooted in the Fin-de-siècle zeitgeist that challenged European modernity and idealized alternatives like the nomadic way of life. Though its ideology was based on the linguistic hypothesis of a Uralo-Altaic family, these nationalists were elite intellectuals from diverse fields - mostly outside linguistics. The Turanian theory did not, however, succeed in linguistics in the twentieth century. Its main challenge came from the Finno-Ugric theorists who argued that the only closest

\footnotetext{
309 Landau, Pan-Turkism, 51.

310 Landau, Pan-Turkism, 53.
} 
relatives of the Magyar language were the Finnic peoples. Building on precedents like the linguistic work of Gyarmathi, Hunfalvy, and Budenz, the Finno-Ugrists claimed that Turkish and its Altaic relatives had no genealogical relationship to Hungarian. Given the decline in the importance of morphological classification in twentieth-century linguistics, similarities in agglutination were not sufficient to relate Hungarian and Turkish together. More linguists now attributed any similarities between these languages to borrowing than to common descent. This new linguistics went against the grand Turanian family that nineteenth-century linguists like Castrén, Müller, and Vambéry had postulated. Serious linguists now treated the Uralo-Altaic or Turanian theory as pseudoscience.

The closing of academic linguistics to the Turanian theory clashed with the continued presence of Pan-Turanism in Hungary and Turkey even after World War I. Though the Turanists were only a peripheral political force owing to their exotic ambitions, their ideology managed to survive even until the twenty-first century through far-right parties like Jobbik in Hungary and the Nationalist Action Party in Turkey. Popular conspiracy theories in Hungary that Western academics wished to discredit the Magyars by denying their glorious Hunnic-Turkic ancestry continued to heat up the emotional intensity of this controversy. The basic outlines of this struggle were already visible in the early twentieth century. The Finno-Ugric theorists set up rival organizations in Hungary and competed for the government's attention against the Turanian Society. The former ridiculed the Turanists as "dilettantes" whose theories were superficial. ${ }^{311}$ Some even treated Pan-Turanism as a "disease" exemplifying the degeneration and 
mysticism of the Fin de siècle —instead of as a remedy for the decay. ${ }^{312}$ Even a former president of the Turanian Society Pal Teleki joined the rival Finno-Ugrists after World War I. ${ }^{313}$ Yet, the continued survival of the Turanian theory in popular culture makes Müller's theory helpful to understand recent cultural productions in the Turanian vein.

As Müller was not directly involved in the Pan-Turanist movement, it might seem that the larger body of Müller's thought was peripheral to Pan-Turanist issues. But in many ways, the pan-nationalists were reacting to evolutionary narratives like those of Müller that celebrated Indo-European or Aryan civilization as the most advanced. By the 1890s, Pan-Turanism rode the intellectual wave of pessimism about Western progress and attempted to celebrate the achievements of the hitherto-underestimated Eurasian pastoral nomads. The Pan-Turanists had rather radical plans to redirect the futures of the Magyars and Turks towards the East. Even ardent White Supremacists in the West like Lothrop Stoddard found during World War I a new awakening of energy and virility among the Turanians - whom he called "the great dynamic of the future." ${ }^{14}$ At the same time, Müller's evolutionary hierarchy of cultures did not entirely fade away in the early twentieth century discussions of Pan-Turanism. For instance, in 1917-18, the British Naval Intelligence produced several reports on the possibility and risks posed by a unified Turanian state to British colonies in Asia. ${ }^{315}$ The navy mostly portrayed the Turanians as weak, scattered, and backward peoples not ready enough to unite by

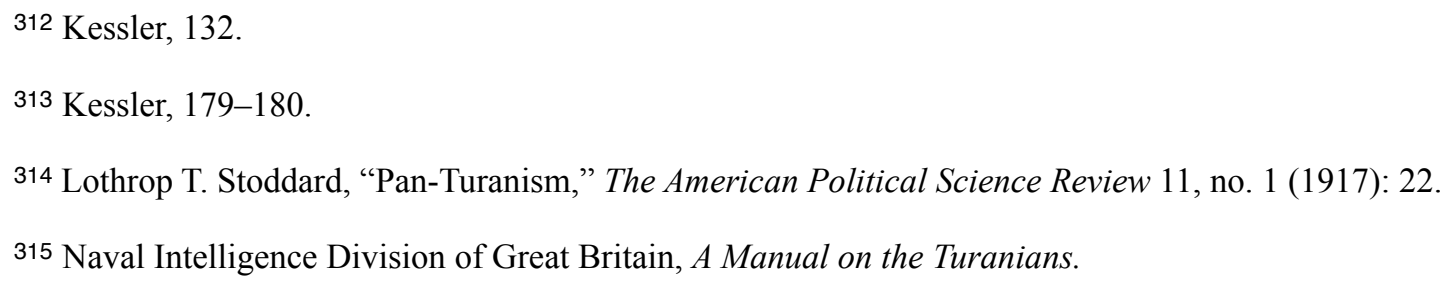


themselves. Both advocates and critics of Pan-Turanism in the twentieth century thus found something relevant to their discourse in the earlier works of Castrén and Müller.

\section{Some Conclusions}

By the late nineteenth century, Müller's influential evolutionary theories of linguistics and religion were increasingly facing challenges in the changing context of the Fin-de-siècle world. An aging scholar by then who was worried about the threats to religion from Darwinism and atheism, Müller himself took up some aspects of the mystical turn in this era against excessive materialism. The Turanian theory took on new roles during this period both in Müller's thought and in the cultural milieus of linguistics and Pan-Turanist nationalism. In each of these areas, the trends were quite heterogeneous and often in contradiction to each other. Müller and the Pan-Turanists retained the idea of a Uralo-Altaic family covering Eastern European and Northern Asian languages, while this theory was gradually phased out in academic linguistics by the mid-twentieth century. The Finno-Ugric theory claiming no genealogical relationship between Magyar and Turkic languages went directly against the desires of the Pan-Turanists. Second, Müller treated Aryan and other cultures in an evolutionary perspective that placed the Indo-Europeans at the most advanced stratum. This rather linear perspective of history and human progress faced serious challenges in both linguistics and Pan-Turanist writings. The emphasis on morphological classification that implied a progression from isolating to inflectional languages came to be discarded in linguistics. The glorification of the nomadic civilizations of Eurasia in relation to the West became common among the Pan-Turanian nationalists. This chapter has shown how contradictory trends like these 
persisted in the same period with each drawing on some Fin-de-siècle trend like cultural degeneration, mysticism, and subjectivity. Many of Müller's theories might no longer be influential, but his insightful points like the separation of racial and linguistic classification and the possibility of monogenesis of all peoples retain enduring significance for humanity. Even the continuation of his Turanian theory in Hungarian and Turkish popular culture oversteps his warnings to avoid superimposing race on language. 


\section{Concluding Thoughts}

Max Müller was not the originator of the concept of the Turanian linguistic family, but his theory of classifying languages promoted the dissemination of this term and informed the later pan-nationalists who aspired to create a vast Turanian state. In today's linguistics, the Turanian or Uralo-Altaic family merely connotes an outmoded and false theory that does not accurately reflect the genealogical relationships among the diverse languages of Europe and Asia. The success of the Finno-Ugric theory relating only the Finnic and Magyar languages has encouraged present-day linguists to focus mostly on this new way of classification. ${ }^{316}$ In this light, it might be tempting to ignore the Turanian theory as a failed one, but the theory's continued presence in the populist far-right culture of Hungary and Turkey today makes it important to study the earlier phases of the idea and its changes through time. ${ }^{317}$ This theory was not always just promoted by right-wing nationalists, but was discussed and debated by linguists like Müller and Whitney who did not have any ties to such pan-nationalists. Moreover, this idea was embedded in nineteenth-century European assumptions about how languages and traditions originated and evolved, and can thus give us a better sense of the intellectual terrain of that era.

\footnotetext{
316 The present-day approach in linguistics of classifying the Uralic and Turkic languages as separate families is detailed in the Routledge Language Family Series. Consult Daniel Abondolo, ed., The Uralic Languages (London: Routledge, 1998) and Johanson Lars and Éva A. Csató, eds., The Turkic Languages (London: Routledge, 1998).

317 The adaptation of Pan-Turanism by the present-day far-right is covered in Emel Akcali and Umut Korkut, "Geographical Meta-narratives in East-Central Europe: Neo-Turanism in Hungary," Eurasian Geography and Economics 53, no. 5 (2012): 596-614; and Kaveh Farrokh, Pan-Turanianism takes aim in Azerbaijan: A Geopolitical Agenda, accessed on 5th September, 2016, http://www.cais-soas.com/CAIS/ Iran/pan turkism takes aim at azarbaijan/part i.htm. Some websites maintained by the Pan-Turanists are Hunmagyar.org, "Hungarian Culture and History," accessed November 5, 2016, http:// www.hunmagyar.org/main.html, and Kurultaj, "Magyarország-Hungary Kurultaj," accessed December 3, 2016, http://kurultaj.hu/english.
} 
Considering Müller's version of this theory, one can find both ideas that were unique to him and those he derived from Castrén and from general trends in comparative linguistics at the time. The privileging of inflectional languages over others was common among nineteenth-century linguists. Yet Müller was unique in interpreting the tripartite morphological evolution of languages in civilizational terms by associating the stages with isolated families, nomadic tribes, and state societies respectively. The relating of languages to social states reflected both his Romantic view of language as inextricably intertwined with human thought and behavior, and his optimism about the relative advancement of European civilization over others in the decade of the Great Exhibition in Victorian England. For Müller, agglutinating languages embodied the primitive nomadic society without centralized states, laws, high culture, and literature, where pastoral migrants lived by hunting, fishing, cattle-breeding, warring, and conquering. Müller differed from his predecessors in arguing that nomadic languages, owing to the chaotic migrations of nomads, splintered much more rapidly into dialects than the languages of advanced societies, and so needed to be classified by different methods. Müller thus brought in a relativistic view questioning the universality of patterns of linguistic change.

Müller's assumptions about the otherness of the nomadic languages factored into his aggregation of all agglutinating languages into the Turanian family. This was idiosyncratic to Müller in the 1850s as he was the first to posit such a large family of Eastern European and Northern and Southern Asian languages. Exempting these languages from tests for systematic sound shifts to prove common descent as in the IndoEuropean case, he held that morphological and a few other grammatical similarities were 
enough to relate nomadic languages. Apart from the agglutination of root words and meaningless affixes in Turanian languages, Müller noted the regularity of terminations denoting grammatical relations like person and gender, and the lack of clear distinctions between nominal and verbal roots. He found patterns like pronominal suffixes (rather than prefixes), vowel harmony, and postpositions common to many Turanian languages. In some cases, he linked the grammar to social conditions of the nomads like their loss of irregular word endings to their forgetting owing to the lack of written historical records of their dialects. In effect, Müller held grammatical likenesses as proof for common descent without rigorously sorting out similarities that merely resulted from lateral borrowing. Also, his deterministic correlation of languages and social states bore the marks of a hierarchical imagination of languages that he later analogized to geological strata.

The interpretation of linguistic and religious change in terms of geological features like strata of rocks was another unique approach Müller introduced to promote the study of these phenomena as comparative sciences. Scholars like William Whewell had already emphasized the broadly historical nature of these human and earth sciences in the nineteenth century, and Müller was not the only linguist employing metaphors from the natural sciences. ${ }^{318}$ However, his use of geological strata to imagine the evolutionary trajectory from isolating to inflectional languages was Müller's own way of defending the hierarchical view of languages as a scientific theory. The agglutinating Turanian stratum was an intermediary stage that the Aryan languages had once passed through. Müller's

\footnotetext{
318 The prevalence of biological metaphors in nineteenth-century linguistics receives detailed coverage in Stephen G. Alter, Darwinism and the Linguistic Image: Language, Race, and Natural Theology in the Nineteenth Century (Baltimore: The Johns Hopkins University Press, 1999).
} 
religious beliefs as a Lutheran associated with the liberal Broad Church colored his ideas

of how languages originated and changed. His stress on the uniqueness of rational speech in humans, on the common origin of languages, and on the possibility of language families transcending racial boundaries came from his universalist religious belief in finding something of value in all people. His passage below—oft-cited by biographerswith its claims of "higher harmonies" of sounds in the "vast ocean" of languages, suggests this shared humanity despite his designation of some languages as primitive:

And now if we gaze from our native shores over that vast ocean of human speech, with its waves rolling on from continent to continent, rising under the fresh breezes of the morning of history, and slowly heaving in our own more sultry atmosphere,- -with sails gliding over its surface and many an oar ploughing through its surf, and the flags of all nations waving joyously together,-with its rocks and wrecks, its storms and battles, yet reflecting serenely all that is beneath, and above, and around it,- -if we gaze, and hearken to the strange sounds rushing past our ears in unbroken strains, it seems no longer a wild tumult ... and the more intensely we listen, the more all discords melt away into higher harmonies, till at last we hear but one majestic trichord, or a mighty unison, as at the end of a sacred symphony. Such visions will float through the mind of the grammarian ... as he feels the conviction growing upon him that men are brethren in the simplest sense of the word - the children of the same father - whatever their country, their colour, their language, and their faith. ${ }^{319}$

Müller's extension of his linguistic classification and geological metaphors to illuminate the study of mythology and religion suggests the interconnectedness of his sciences. Müller used a similar comparative and historical approach to study myths and religions, beginning with collecting facts about different cases and making inductive conclusions. His very idea of comparing other religions and their folklore with Christianity was controversial in Victorian England, particularly among conservative Anglicans who distrusted his links to the Broad Church. Müller was himself trying to 
defend religious faith from atheism through a search for universal values in all religions, and argued for religion as a product of human rationality and their curiosity about natural phenomena. It was only mythology that was a deviant regressive stage in the evolution of thought owing to the confusion caused by language, while he expected religions to progress through stages to the highest mysticism. Religions with multiple ancestral and natural spirits like those of the Turanians embodied an early stage before humanity progressed towards monotheism. The "henotheistic" religious stage of the Turanians with no clear supreme God in their pantheons paralleled the nomadic state of their languages in which the splintering of dialects was rampant in the absence of centralized states.

The peculiarities of Müller's imagination of the Turanian family need to be situated in the context of his contemporary linguistics and its practitioners. The progression of languages from the isolating to inflectional stages was a fairly common idea in the early nineteenth century, with linguists like Bopp, Humboldt, Schleicher, and Castrén using their own variants of this hypothesis. It was perhaps Castrén's fieldwork on the Northern Asian and Finnic languages that influenced Müller most in envisioning a large family of such languages. Castrén's travels to Lapland, the Urals, and Siberia in the late 1830s and '40s had enabled him to collect and publish grammatical details about hitherto littleknown dialects of these regions. Castrén's theory of an "Altaic" family including Finnish, Hungarian, Turkish, and Northern Asian languages somewhat overlapped genealogy with their agglutinating feature, though he distinguished the two phenomena. Claiming that the Finnic branch was closest to reaching the inflectional stage, he too approved of the supposedly advanced nature of inflections. Castrén was similar to Müller in these aspects, 
but did not make a clear distinction between language families and racial or ethnic similarities. It was Müller who separated these groupings and recognized the complexity of how people of different racial groups might share a cognate dialect. This nuance implied the limitations of merely using language to trace the prehistory of a people.

The influence of Müller's linguistic classification on later movements like PanTuranist nationalism forms another significant theme in this thesis. As an academic and political movement, this pan-nationalism emerged towards the end of Müller's life in the 1890s and took interest in the supposed Eastern relatives of the Hungarians and Turks postulated by Castrén and Müller. The pan-nationalists, however, differed from earlier linguists in that the cultural pessimism towards Western civilization during the Fin de siècle informed the rise of the Pan-Turanists in Hungary and the Ottoman Empire. They challenged the evolutionary hierarchies in nineteenth-century European texts and found positive virtues in the nomadic heritage of the Uralo-Altaic peoples. This new orientation inspired the Pan-Turanists to turn eastward and think about political alliances with their fellow Turanians rather than the West. Around the same time, linguists too questioned the ethnocentrism, linear ideas of progress, and claims to objectivity that buttressed the hierarchies of languages in the nineteenth century. These changes meant that theories like Müller's became obsolete by the early twentieth century, when evolutionary theories fell out of favor given the pessimism caused by the world wars. Yet his classification of languages still continues to influence right-wing nationalist ideologies like Pan-Turanism in ways that he never intended. This is one case of the broader phenomenon of nineteenth-century theories getting appropriated by later nationalists. 


\section{Bibliography}

\section{Primary Sources by Max Müller}

Müller, F. Max. Rigveda Samhita. The Sacred Hymns of the Brahmans together with the Commentary of Sayanacarya. 6 vols. Oxford, 1849-74.

. "Letter on Turanian Languages." In Christianity and Mankind, vol. III, edited by C. C. J. Bunsen, 1854, 1-274.

. The Languages of the Seat of War in the East (2nd edition). London: Williams and Norgate, 1855.

Comparative Mythology: An Essay; originally published in 1856. London: George Routledge \& Sons., Limited, 1909.

. Deutsche Liebe (German Love): Fragments from the Papers of an Alien; originally published in 1857. London: W. Swan Sonnenschein \& Co., 1884.

- A History of Ancient Sanskrit Literature, so far as it illustrates the Primitive Religion of the Brahmans. London: Williams and Norgate, 1859.

- Chips from a German Workshop. 2 vols. London: Longmans, Green, \& Co. 1867.

. On the Stratification of Language. London: Longmans, Green, Reader, and Dyer, 1868.

- Lectures on the Science of Religion. New York: Scribner, Armstrong, \& Co., 1872.

- Lectures on Mr. Darwin's Philosophy of Language: Delivered at the Royal Institution in March and April 1873. London: Longmans, Green, \& Co., 1873.

- Lectures on the Science of Language Delivered at the Royal Institution of Great Britain in 1861 [and 1863]. 2 vols.; originally delivered in 1861 and 1863. New York: Scribner, Armstrong, \& Co., 1873.

- Lectures on the Origin and Growth of Religion, as Illustrated by the Religions of India (first edition, 1878; new edition, 1882). London: Longmans, Green, \& Co., 1879. 
_. India: What Can It Teach Us? New York: John W. Lovell Co., 1883.

—. The Science of Thought. London: Longmans, Green, \& Co. 1887.

. Biographies of Words and the Home of the Aryas. London: Longmans, Green, \& Co., 1888.

- Natural Religion. London: Longmans, Green, \& Co., 1889.

- Physical Religion. London: Longmans, Green, \& Co., 1891.

—. Anthropological Religion. London: Longmans, Green, \& Co., 1892.

- Theosophy, or Psychological Religion. London: Longmans, Green, \& Co., 1893.

- Three Lectures on the Vedanta Philosophy. London: Longmans, Green, \& Co., 1894.

- Contributions to the Science of Mythology. 2 vols. London: Longmans, Green, \& Co., 1897.

- Last Essays: Essays on the Science of Religion. London: Longmans, Green, \& Co., 1901.

—. My Autobiography: A Fragment. New York: Charles Scribner's Sons, 1901.

- The Life and Letters of the Right Honorable Friedrich Max Müller. Edited by Georgina Max Müller. 2 vols. London: Longmans, Green, \& Co., 1902.

- The Essential Max Müller: On Language, Mythology, and Religion, edited by Jon R. Stone. New York: Palgrave, Macmillan, 2002.

\section{Primary Sources relating to Pan-Turanism}

Arnakis, George. "Turanism: An Aspect of Turkish Nationalism.” Balkan Studies 1 (1960): 19-32.

Castrén, Matthias Alexander. Ethnologische Vorlesungen über die altaischen Völker nebst samojedischen Märchen und tatarischen Heldensagen. Translated from the Finnish into German by Franz Anton Schiefner. St.Petersburg: Buchdruckerei der Kaiserlichen Akademie der Wissenschaften, 1857. 
Farrokh, Kaveh. Pan-Turanianism takes aim in Azerbaijan: A Geopolitical Agenda. Accessed on 5th September, 2016. http://www.cais-soas.com/CAIS/Iran/ pan_turkism takes_aim_at_azarbaijan/part_i.htm.

Great Britain Foreign Office. The Rise of the Turks: The Pan-Turanian Movement. The British Foreign Office, 1919.

Hartwig, Georg. The Polar World: A Popular Description of Man and Nature in the Arctic and Antarctic Regions of the Globe. London: Longmans and Green, 1869.

Hunmagyar.org. "Hungarian Culture and History.” Accessed November 5, 2016. http:// www.hunmagyar.org/main.html.

Kurultaj. "Magyarország-Hungary Kurultaj.” Accessed December 3, 2016. http:// kurultaj.hu/english.

Macdonell, Arthur Anthony. "Pan-Turanianism.” Encyclopedia Britannica (12th ed.).

Naval Intelligence Division of Great Britain. A Manual on the Turanians and PanTuranianism. Oxford: Oxford University Press, November 1918.

Schlegel, Friedrich. "On the Language and Wisdom of the Indians," in The Aesthetic and Miscellaneous Works of Friedrich von Schlegel. Translated by Ellen J. Millington. London: Henry G. Bohn, 1849.

Stoddard, Lothrop T. "Pan-Turanism.” The American Political Science Review 11, no. 1 (1917): 12-23.

Szilagyi, Adam. “Turan.” Magyar Nyelvor, 1916.

Toynbee, A. J. Report on the Pan-Turanian Movement. London: Intelligence Bureau Department of Information, Admiralty, L/MIL/17/16/23, 1917.

Vámbéry, Ármin. Arminius Vambery: His Life and Adventures. London: T. Fischer Unwin, 1889.

Zempléni, Árpád. Turanian Songs: Legendary and Historical Hero-Songs. Budapest, New York: Franklin Society, 1916.

\section{Secondary Sources on Max Müller and General Intellectual History}

Aarsleff, Hans. The Study of Language in England, 1780-1860. Princeton, NJ: Princeton 
University Press, 1967.

. From Locke to Saussure: Essays on the Study of Language and Intellectual History. Minneapolis: University of Minnesota Press, 1982.

Achelis, Th. Max Müller und die vergleichende Religionswissenschaft. 2 vols. Hamburg, 1893.

Alter, Stephen G. Darwinism and the Linguistic Image: Language, Race, and Natural Theology in the Nineteenth Century. Baltimore: The Johns Hopkins University Press, 1999.

Amsterdamska, Olga. Schools of Thought: The Development of Linguistics from Bopp to Saussure. Dordrecht, Holland: D. Reidel Publishing Company, 1987.

Benes, Tuska. In Babel's Shadow: Language, Philology, and the Nation in NineteenthCentury Germany. Detroit, MI: Wayne State University Press, 2008.

Blackbourn, David. The Long Nineteenth Century: A History of Germany 1780-1918. New York: Oxford University Press, 1997.

Bosch, Lourens P. van den. Friedrich Max Müller: A Life Dedicated to the Humanities. Leiden: Brill, 2002.

—_. "Friedrich Max Müller: His Contributions to the Science of Religion," In Comparative Studies in History of Religions, edited by E. Reenberg Sands and J. P. Sorenson. Copenhagen, 1999.

—_. "Language as the Barrier between Man and Brute: Friedrich Max Müller and the Darwinian Debate on Language." Saeculum 51 (2000), 57-89.

Bourdon, B. "F. Max Müller. The Science of Thought" (book review). Revue philosophique de la France et de l'Etranger, vol. 25 (1888): 95-103.

Burrow, John W. The Crisis of Reason: European Thought 1848-1914. New Haven: Yale University Press, 2000.

Chaudhuri, Nirad C. Scholar Extraordinary: The Life of Professor the Rt Hon. Friedrich Max Müller. New York: Oxford University Press, 1974.

Davis, John R., and Angus Nicholls, eds. Friedrich Max Müller and the Role of Philology in Victorian Thought. London: Routledge, 2018 (forthcoming). 
Eco, Umberto. The Search for the Perfect Language. Translated by James Fentress. Oxford: Basil Blackwell, 1995.

Girardot, Norman. "Max Müller's Sacred Books and the Nineteenth-Century Production of the Comparative Science of Religion," History of Religions 41 (February 2002): 213-250.

Greenberg, Joseph. Language Typology: A Historical and Analytical Overview. The Hague: Mouton, 1974.

Green, Thomas J. Religion for a Secular Age: Max Müller, Swami Vivekananda, and Vedanta. London: Routledge, 2016.

Gruppe, O. "Review of Max Müller's Contribution to the Science of Mythology." Archiv für Religionswissenschaft, 1899, 268-280.

Hovelacque, Abel. The Science of Language: Linguistics, Philology, and Etymology. London: Chapman and Hall, 1877.

Jankowski, Kurt R. "F. Max Müller and the Development of Linguistic Science." Historiographica Linguistica 6 (1979): 339-59.

Kitagawa, Joseph M., and John S. Strong. "Friedrich Max Müller and the Comparative Study of Religion." In Nineteenth Century Religious Thought in the West (vol. 3), edited by Ninian Smart, John Clayton, Stephen Katz, and Patrick Sherry. Cambridge: Cambridge University Press, 1985, 179-213.

Knoll, Elizabeth. "The Science of Language and the Evolution of Mind: Max Müller's Quarrel with Darwinism." Journal of the History of the Behavioral Sciences 22 (1986): 3-22.

Lang, Andrew. "Mr. Max Müller and Fetishism." Mind: quarterly Review of Psychology and Philosophy IV (1879): 453-69.

__. "Mr. Müller's Philosophy of Mythology." Fraser's Magazine 24 (1881): 16686.

."The Theories of Max Müller.” Contemporary Review 93 (1900).

Manley K. A. "Max Müller and the Bodleian Sub-librarianship, 1865." Library History, vol. V (1981): 33-47. 
Molendijk, Arie. Friedrich Max Müller and the Sacred Books of the East. Oxford: Oxford University Press, 2016.

Neufeldt, Ronald W. Friedrich Max Müller and the Rigveda: A Study of its Role in his Work and Thought. Calcutta, 1980.

Noire, Ludwig. Max Müller and the Philosophy of Language. London: Longmans, Green, \& Co., 1879.

O’Grady, William and John Archibald. Contemporary Linguistics: An Introduction. Boston: Bedford/St. Martin's, 2010.

Olson, Richard G. Science and Scientism in Nineteenth-Century Europe. Urbana and Chicago: University of Illinois Press, 2008.

Réville, A. "Max Müller, Physical Religion" (book review). Revue de l'histoire des religions, vol. 24 (1891): 102-107.

Robins, Robert H. A Short History of Linguistics. London and New York: Longman Group, 1990.

Said, Edward. Orientalism. New York: Vintage Books, 1979.

Sebeok, Thomas A., eds. Portraits of Linguists: A Biographical Source Book for the History of Western Linguistics, 1746-1963. Bloomington: Indiana University Press, 1967.

Sharpe, Eric. Comparative Religion: A History. New York: Charles Scribner's Sons, 1975.

Stocking, George W. Jr. Victorian Anthropology. New York: The Free Press, 1987.

Strenski, Ivan. "The Rise of Ritual and the Hegemony of Myth: Sylvan Lévi, the Durkheimians, and Max Müller.” In Myth and Method, edited by Laurie L. Patton and Wendy Doniger. Charlottesville: University of Virginia Press, 1996, 52-81.

Sutcliffe, Patricia Casey. "Friedrich Max Müller and William Dwight Whitney as Exporters of Nineteenth-Century German Philology: A Sociological Analysis of the Development of their Linguistic Theories." PhD Diss., University of Texas at Austin, 2000. 
Trompf, Garry W. Friedrich Max Müller: As a Theorist of Comparative Religion. Bombay: Shakuntala Publishing House, 1978.

Tull, Herman. 'F. Max Müller and A. B. Keith: 'Twaddle,' the 'Stupid' Myth, and the Disease of Indology." Numen 38 (June, 1991): 27-58.

Winders, James A. European Culture since 1848: From Modern to Postmodern and Beyond. New York: Palgrave, 2001.

Whitney, William Dwight. Max Müller and the Science of Language. New York: D. Appleton \& Co., 1892.

\section{Secondary Sources relating to Pan-Turanism}

Abondolo, Daniel, ed. The Uralic Languages (Routledge Language Family Series). London: Routledge, 1998.

Akcali, Emel and Umut Korkut. "Geographical Meta-narratives in East-Central Europe: Neo-Turanism in Hungary." Eurasian Geography and Economics 53, no. 5 (2012): 596-614.

Barfield, Thomas J. The Nomadic Alternative. Englewood Cliffs, NJ: Prentice Hall, 1993.

Kessler, Joseph A. “Turanism and Pan-Turanism in Hungary 1890-1945.” PhD Diss., University of California, Berkeley, 1967.

Khazanov, A. M. Nomads and the Outside World. Translated by Julia Crookenden. Cambridge: Cambridge University Press, 1983.

Kradin, N. Nikolay. "Nomadism, Evolution, and World-Systems: Pastoral Societies in Theories of Historical Development." Journal of World-System Research 8 (2002): 368-388.

Kradin, N. Nikolay, Dmitri M. Bondarenko, and Thomas J. Barfield, eds. Nomadic Pathways in Social Evolution. Moscow: Russian Academy of Sciences, Center for Civilizational and Regional Studies, 2003.

Landau, Jacob. “Arminius Vambéry: Traveller, Scholar, Politician.” Middle Eastern Studies 50 (2014): 857-869.

Landau, Jacob. Pan-Turkism: From Irredentism to Cooperation. Bloomington, Indiana: Indiana University Press, 1995. 
Lars, Johanson and Éva A. Csató, eds. The Turkic Languages (Routledge Language Family Series). London: Routledge, 1998.

Mandler, David. “Arminius Vámbéry, Victorian Culture, and Stoker's Dracula.” In Comparative Hungarian Cultural Studies, edited by Steven Tötösy de Zepetnek and Louise O. Vasvári. West Lafayette, IN: Purdue University Press, 2015.

Marcantonio, Angela, Pirjo Nummenaho, and Michela Salvagni. "The 'Ugric-Turkic Battle': A Critical Review.” Linguistica Uralica 2 (2001): 81-102.

Molnár, Miklós. A Concise History of Hungary. Translated by Anna Magyar. Cambridge: Cambridge University Press, 2001.

Oguz, Alaattin. "The Interplay between Turkish and Hungarian Nationalism: Ottoman Pan-Turkism and Hungarian Turanism (1890-1918)." MS Diss., The Middle East Technical University, 2005.

Poulton, Hugh. Top Hat, Grey Wolf, and Crescent: Turkish Nationalism and the Turkish Republic. London, England: Hurst, 1997.

Winternitz, Judith. "The 'Turanian' Hypothesis and Magyar Nationalism in the Nineteenth Century," In Culture and Nationalism in the Nineteenth-Century Eastern Europe, edited by Roland Sussex \& J. C. Eade, Ohio: Slavica Publishers, 1985.

Zenkovsky, Serge A. Pan-Turkism and Islam in Russia. Cambridge, MA: Harvard University Press, 1960. 